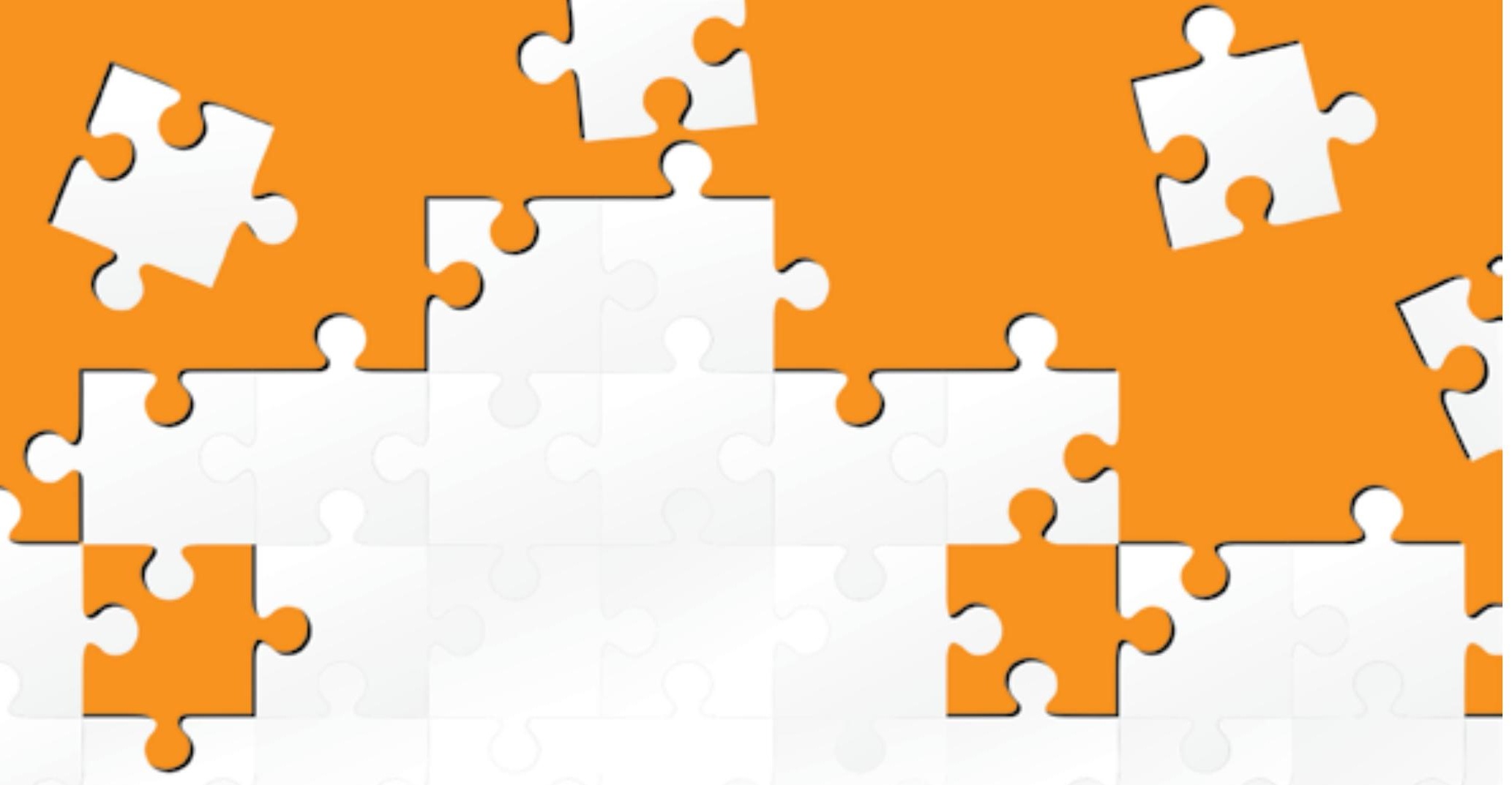

Cadernos da

SAÚDE COLETIVA

Inovações na formação de sanitaristas

Organizadores

Alcindo Antônio Ferla

Cristianne Maria Famer Rocha 

Alcindo Antônio Ferla

Cristianne Maria Famer Rocha

Cadernos da

SAÚDE COLETIVA

Inovações na formação de sanitaristas

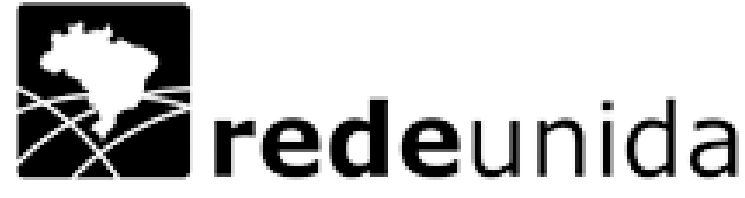

1ª edição

Porto Alegre, 2013 


\section{Cadernos da Saúde Coletiva Inovações na formação de sanitaristas}

\section{Coordenador Nacional da Rede Unida}

Alcindo Antônio Ferla

\section{Coordenação Editorial}

Alcindo Antônio Ferla

\section{Conselho Editorial}

Alcindo Antônio Ferla

Emerson Elias Merhy

Laura Camargo Macruz Feuerwerker

Rossana Baduy

Vanderléia Daron

João Campos

Márcia Regina Cardoso Torres

Vera kadjaoglanian

Rocineide Ferreira

Julio César Schweickardt

\section{Comissão Executiva Editorial}

Janaina Matheus Collar

João Beccon de Almeida Neto

\section{Capa, Projeto Gráfico e Diagramação}

Raquel Amsberg de Almeida

\section{DADOS INTERNACIONAIS PARA CATALOGAÇÃO NA PUBLICAÇÃO (CIP)}

I58 Inovações na formação de sanitaristas / organizadores: Alcindo Antonio Ferla, Cristianne Maria Famer Rocha. - Porto Alegre: Rede UNIDA, 2013.

72 p.: il. - (Cadernos da Saúde Coletiva; v.1)

Bibliografia

ISBN 978-85-66659-07-8

1. Educação em saúde 2. Saúde pública 3. Sistemas de saúde 4. Sistema Único de Saúde I. Ferla, Alcindo Antônio II. Rocha, Cristianne Maria Famer III. Título IV. Série 
INOVAÇÕES NA FORMAÇÃO DE SANITARISTAS: UMA INICIATIVA PARA O SUS. .9

A FORMAÇÃO EM SAÚDE COLETIVA E AS DIRETRIZES CURRICULARES NACIONAIS DA ÁREA DA SAÚDE: REFLEXÕES E UM COMEÇO DE CONVERSA.

CURSO DE ANÁLISE DE POLÍTICAS E SISTEMAS DE SAÚDE: DETALHAMENTO DO PROJETO PEDAGÓGICO.

A UNIDADE DE PRODUÇÃO PEDAGÓGICA COMO ATIVIDADE DE ENSINO NO CURSO DE ANÁLISE DE POLITICAS E SISTEMAS DE SAÚDE. 



\section{INOVAÇÕES NA FORMAÇÃO DE SANITARISTAS: UMA INICIATIVA PARA O SUS}

A criação de cursos de graduação em Saúde Coletiva representa um amadurecimento da área e uma demanda do Sistema Único de Saúde (SUS). O acelerado crescimento dos conhecimentos disponíveis em todas as áreas e o limite do alcance da especialização como recurso para atribuir núcleos de saber para diferentes profissões é marco do processo das novas profissões. Mais do que um fenômeno do mundo do conhecimento, a avaliação da necessidade de um profissional que se ocupasse as capacidades que transcendem os núcleos assistenciais na saúde é fato registrado em diversos documentos seminais da área. Quem não recorda de alguma das últimas Conferências Nacionais de Saúde reivindicando novas capacidades profissionais para o exercício da gestão, da vigilância? Ou, mesmo, a distância entre as diretrizes legais para a educação na saúde e o cotidiano do SUS?

Não se trata mais de afirmar apenas a transversalidade da Saúde Coletiva nas demais profissões da saúde, conforme consta nas diretrizes que orientam as mudanças na formação dos profissionais da área. Trata-se da afirmação da Saúde Coletiva também como campo de exercício profissional, ampliado, para além da especialização em subnúcleos, como nos programas de pós-graduação.

O Curso de Análise de Políticas e Sistemas de Saúde - Bacharelado em Saúde Coletiva, na Universidade Federal do Rio Grande do Sul, nasceu articulado com essas ideias, mas também na necessidade de inovações pedagógicas: para formar um novo profissional, era preciso avançar no desenho curricular e nas práticas pedagógicas. Não se faz o novo com o mesmo. E a reflexão cotidiana sobre esse novo fazer atravessou a elaboração do Projeto Pedagógico do Curso e a produção de práticas com renovada potencialidade de produzir aprendizagens. Aprendizagens necessárias ao conjunto de atores, só para relembrar de Paulo Freire, que registrava que a capacidade renovada de ensinar se esgota quando se alcança o limite da capacidade de aprender.

Esse número dos Cadernos da Saúde Coletiva apresenta parte do aprendizado coletivo sobre o ensinar e os modos de fazê-lo. Compartilha o Projeto Pedagógico do Curso, crivado de invenções e inovações, mas também algumas reflexões de maior fôlego sobre a organização de atividades de ensino não disciplinares (as Unidades de Produção Pedagógica - UPP), sobre o uso de portfólios avaliativos em atividades de tutoria e sobre a definição de diretrizes curriculares para o novo curso.

Reflexões datadas, mas com atualidade e potência de semear ainda mais inovações. A organização dos Cadernos e desse volume em particular é um convite ao diálogo. Mais do que o compartilhamento da experiência, um diálogo para avançar a passos ainda mais largos em direção ao compromisso ético com a saúde e com as politicas públicas voltadas à qualificação e ampliação da vida. Desejamos que os Cadernos produzam rodas e redes, no cotidiano do sistema de saúde e da formação das diferentes profissões que fazem esse cotidiano.

Boa leitura! 



\section{A FORMAÇÃO EM SAÚDE COLETIVA E AS DIRETRIZES CURRICULARES NACIONAIS DA ÁREA DA SAÚDE: REFLEXÕES E UM COMEÇO DE CONVERSA}

As politicas nacionais de educação e de educação na saúde vêm induzindo processos de mudança na formação dos profissionais da chamada Área da Saúde, não apenas às profissões relacionadas na Tabela de Áreas do Conhecimento da Coordenação de Aperfeiçoamento do Pessoal de Nivel Superior - Capes, mas às profissões com forte ou moderada atuação no setor. A direção desses processos de mudança, mais que relativa às orientações sobre a distribuição da carga horária e sobre os conteúdos de ensino obrigatório, corresponde à implementação de diretrizes curriculares nacionais e ao debate sobre perfil dos egressos da educação superior. No caso da saúde, essas diretrizes foram resultantes de um movimento social de mudanças nessa própria área, organizada no país como Sistema Único de Saúde (SUS) e com registro de diversos movimentos sociais de mudança na graduação.

Um histórico desses processos foi sumarizado pelos pareceres e resoluções do Conselho Nacional de Educação que propuseram e aprovaram as diretrizes curriculares nacionais em processo que se estendeu de 1997 a 2001. Os diversos pareceres e resoluções que envolvem cursos da área da saúde estão listados no quadro anexo, incluindo os endereços eletrônicos para o acesso aos mesmos, facilitando uma análise em maior profundidade quanto às especificidades de cada profissão.

Utilizamos, para efeitos de nossa reflexão e conversa, o Parecer CNE/CES n $1.133 / 2001$, que inclui os cursos de Enfermagem, Medicina e Nutrição e as Resoluções CNE/CES n 03,04 e 05/2001, dos respectivos cursos, naquilo que corresponde às competências e habilidades gerais de tais profissões, que são idênticas entre si e desenham, pela primeira vez um conceito de Área. As competências e habilidades gerais dizem respeito à área, enquanto as competências e habilidades específicas dizem respeito às profissões em particular.

Uma primeira noção de Área foi utilizada pelo Ministério da Educação ao chamar o Edital de confecção das Diretrizes Curriculares Nacionais, onde um dos agregados foi "Ciências Biológicas e da Saúde", reconhecendo a Tabela de Áreas do Conhecimento da Capes. Uma noção complementar foi utilizada pelo Conselho Nacional de Educação quando articulou Área de Conhecimento e Área de Atuação, desdobrando particularidades às profissões que se apresentam diversamente entre Área de Conhecimento e Ârea de Atuação, como a Educação Física, que deve contemplar a formação para atuação em setores como a saúde, o esporte e a educação, sem predomínio de atuação na saúde, embora ciência da saúde. Outras profissões se enquadram em áreas de domínios conexos entre ciências da saúde e as ciências biológicas, ciências humanas, ciências sociais aplicadas e ciências agrárias, complexificando esse debate e conversa.

Como foco da presente discussão sobre a reorientação da formação na Área da Saúde e a presença da Saúde Coletiva, reconhecemos o agregado que coincide Áreas do Conhecimento, uti-

1 Professores do Curso de Análise de Políticas e Sistemas de Saúde - Bacharelado em Saúde Coletiva, da Universidade Federal do Rio Grande do Sul. 
lizando a Tabela da Capes (versão de 1984, atualmente em vigor) e o Edital MEC n 04/1997 (relativo às Diretrizes Curriculares Nacionais) e Área de Atuação, utilizando os Indicadores de Gestão do Trabalho em Saúde/Programa de Qualificação e Estruturação da Gestão do Trabalho no Sistema Único de Saúde (ProgeSUS), de 2007. A área da Saúde Coletiva que consta da Tabela da Capes, não constou no Edital MEC por não representar, à época, curso de graduação, tendo constado nos Indicadores de Gestão do Trabalho em Saúde por representar ocupação profissional no sistema de saúde.

A classificação das Áreas do Conhecimento, para o setor da Educação (há diferença no setor na Ciência e Tecnologia), apresenta uma hierarquização em cinco níveis, que vão do mais geral aos mais específicos, abrangendo 09 Grandes Áreas, 79 Áreas e 344 Subáreas do conhecimento, além de Especialidades. Na Grande Área da Saúde, consta a Área da Saúde Coletiva, que contempla Subáreas e Especialidades. Uma especialidade como a Biomedicina (Ciências Biológicas - "Modalidade" Médica), em todas as versões da Tabela de Áreas do Conhecimento (a primeiro é de 1976, as seguintes são de 1982 e 1984) dentre as Ciências Biológicas, foi reconhecida como profissão em 1979. Com a Saúde Coletiva, iniciada no ensino de graduação a partir de 2008, acontece de encontrarmos cursos identificados com a Área, especificamente uma de suas Subáreas ou, ainda, suas Especialidades. Tentaremos, então, contribuir à compreensão dos cursos de graduação na área da Saúde Coletiva, mas, em especial, do curso de Análise de Políticas e Sistemas de Saúde - Bacharelado em Saúde Coletiva, da Universidade Federal do Rio Grande do Sul (UFRGS).

Será feita uma análise descritiva das recomendações curriculares e de perfil de egresso, segundo alguns recortes considerados importantes para o objetivo das Diretrizes Curriculares para a Área da Saúde. Destacamos como Área da Saúde, então, aquele escopo das Diretrizes Curriculares que institui um artigo em comum ao grupo, o Art. $4^{\circ}$ - Competências e Habilidades Gerais em Saúde e um Parágrafo Único ao Art. $5^{\circ}$ - Competências e Habilidades Específicas da Profissão, onde é registrado que todas as competências e habilidades próprias da profissão ficam submetidas à apropriação do sistema de saúde vigente no país, ao trabalho em equipe de saúde e à integralidade da atenção. Citamos o Parágrafo Único, do Art. $5^{\circ}$ das Diretrizes Curriculares Nacionais dos já nominados cursos de Enfermagem, Medicina (texto idêntico para os cursos de Odontologia, Fisioterapia, Fonoaudiologia e Terapia Ocupacional) e Nutrição, mais o curso de Farmácia para contemplar as diversas redações do grupo de profissões da Área de Conhecimento da Saúde (as respectivas Resoluções encontram-se no Anexo 1):

\section{- Enfermagem}

Parágrafo Único. A formação do Enfermeiro deve atender as necessidades sociais da saúde, com ênfase no Sistema Único de Saúde (SUS) e assegurar a integralidade da atenção e a qualidade e humanização do atendimento.

- Medicina (igual para Odontologia, Fisioterapia, Fonoaudiologia e Terapia Ocupacional)

Parágrafo único. A formação do médico [cada profissional] deverá contemplar o sistema de saúde vigente no país, a atenção integral da saúde num sistema regionalizado e hierarquizado de referência e contra-referência e o trabalho em equipe.

- Nutrição

Parágrafo Único. A formação do nutricionista deve contemplar as necessidades sociais da saúde, com ênfase no Sistema Único de Saúde (SUS).

- Farmácia

Parágrafo único. A formação do Farmacêutico deverá contemplar as necessidades sociais da saúde, a atenção integral da saúde no sistema regionalizado e hierarquizado de referência e contra-referência e o trabalho em equipe, com ênfase no Sistema Único de 
Saúde (SUS).

Os cursos da Área da Saúde Coletiva são cursos novos, ainda sem diretrizes curriculares nacionais, por isso a UFRGS utilizou-se do debate e da construção e embasamento do grupo de profissões de identificação com o núcleo do conhecimento e da atuação na saúde, ou seja, competências e habilidades específicas em identidade com o sistema de saúde vigente no país, o trabalho em equipe de saúde e a integralidade da atenção, além das regulações próprias ao setor da saúde, representado pelas normativas geradas ao trabalho, formação, pesquisa e desenvolvimento no Sistema Único de Saúde.

\section{Histórico}

O Parecer CNE/CES n ${ }^{\circ} 1.133 / 2001$ introduz o debate sobre a necessidade de um novo quadro normativo para o ensino de graduação na saúde a partir dos principais marcos conceituais introduzidos pelos setores da Saúde (Constituição Brasileira, Leis Orgânicas da Saúde, Relatórios Finais das Conferências Nacionais de Saúde e Leis de Exercício Profissional em Saúde) e da Educação (Lei de Diretrizes e Bases da Educação Nacional, Plano Nacional de Educação e Jurisprudências do CNE e do MEC), bem como documentos básicos da responsabilidade social e relevância pública de ambas as áreas. A importância dessa "introdução" é o reconhecimento explícito de uma articulação entre as áreas, inédito na história nacional, assim como o reconhecimento de "área" ao grupo de cursos que forma profissionais para o setor da saúde, como previa o Art. 200, da Constituição Federal.

A metodologia utilizada para a construção das diretrizes, no caso da área da saúde, incluiu a análise de experiências prévias de mudança na formação, iniciativas isoladas com registro de sucesso nas inovações em saúde e um processo participativo que envolveu uma ampla gama de entidades e fóruns da área, além do próprio Conselho Nacional de Saúde. O saldo é relevante para o conceito de Área às profissões da saúde, não apenas uma formação específica em cada profissão, mas uma formação generalista no campo. A relevância é tal que mesmo cursos de outras áreas do conhecimento, com forte ou moderada atuação no setor da saúde, perfilaram suas diretrizes curriculares nacionais às diretrizes do "campo" da saúde. A diferença no "campo" fica reduzida para as áreas com domínios conexos ou relativamente às várias subáreas e especialidades, devido à necessidade da interdisciplinaridade em conhecimentos complexos. Tendo em vista o formato das Diretrizes Curriculares Nacionais, escolhemos o debate da identidade no Art. $4^{\circ}$ e no Parágrafo Único do Art. $5^{\circ}$.

\section{Diretrizes Curriculares Nacionais como estratégia para a mudança no ensino}

A proposição de diretrizes curriculares nacionais - como estratégia de orientação às mudanças no ensino - está, em primeiro lugar, na mudança da noção de "currículo mínimo" ou "obrigatório" para a noção de "diretrizes". Esta mudança é definida e argumentada no Parecer da seguinte forma:

As diretrizes curriculares constituem orientações para a elaboração dos currículos que devem ser necessariamente adotadas por todas as instituições de ensino superior. Dentro da perspectiva de assegurar a flexibilidade, a diversidade e a qualidade da formação oferecida aos estudantes, as diretrizes devem estimular o abandono das concepções antigas e herméticas das grades (prisões) curriculares, de atuarem, muitas vezes, como meros instrumentos de transmissão de conhecimento e informações, e garantir uma sólida formação básica, preparando o futuro graduado para enfrentar os desafios das rápidas transformações da sociedade, do mercado de trabalho e das condições de exercício profissional (Parecer CNE/ CES n 1.133, grifo nosso). 
Vê-se que há uma escolha por sair da distribuição de conteúdos e carga horária predefinidos em grades curriculares, abandonar o desenho de cursos iguais (independentemente de região de inserção e do compromisso local com intervenções sensiveis à presença do ensino e pesquisa universitários) e assumir a interação criativa entre docentes e destes com seus aprendizes de modo que a formação diga respeito à ciência, mas especialmente às interações de aprendizagem.

O desafio que essas diretrizes colocam é à capacidade de invenção institucional e à capacidade de ensinar e aprender ativamente. O parâmetro deve ser o do desenvolvimento de competências/habilidades profissionais em substituição ao atestado de cumprimento das jornadas de estudo em conhecimento e práticas comprovados por notas e presenças. Esta exigência troca de lugar, de uma noção formal e cartorial para um compromisso reciproco entre docentes e discentes, assim como da instituição de ensino. A proposição de diretrizes para orientar a formação parte do reconhecimento da grande diversidade de cenários do país e de que isso não é um problema, ao contrário, trata-se da potência de diferir, inovar, criar e aprender a aprender. De toda forma, o reconhecimento de que há diversidade de campos de atuação profissional, com recortes territoriais e culturais, representa um grande avanço na forma como políticas nacionais induzem à organização da formação. Há que se garantir, portanto, que conhecimentos e práticas expressivos de cada campo do saber e cada núcleo profissional estejam assegurados. Não é porque o campo da cultura é relevante para a saúde que a formação em saúde se fará no campo da cultura ou que profissões da cultura serão formadas no campo da saúde. Mesmo que a antropologia seja relevante à saúde, seu campo é o das ciências humanas, não o da saúde. Mesmo que a saúde coletiva requeira a antropologia em sua formação, seu campo é o da saúde, não o das ciências humanas. Quanto ao núcleo de conhecimentos, a mesma coisa, não é possivel que o enfermeiro desconheça práticas educativas em saúde, que o médico desconheça a patognomonia das doenças, que o nutricionista desconheça o aporte de energia e nutrientes dos alimentos ou que o sanitarista desconheça análise de sistemas e políticas de saúde.

É necessário que a formação se utilize das melhores capacidades locais e da plena interface com os sistemas de saúde, mas há uma mudança conceitual importante também no que se define como resultado da formação em graduação: não mais um protótipo serializado, mas um sujeito com capacidade de atuação criativa e protagônica nos cenários do sistema de saúde, inclusive com capacidade de aprender continuamente em contato com o chamado "mundo do trabalho". De acordo com o referido Parecer, é necessário que os cursos contemplem:

(...) elementos de fundamentação essencial em cada área do conhecimento, campo do saber ou profissão, visando promover no estudante a competência do desenvolvimento intelectual e profissional autônomo e permanente. Esta competência permite a continuidade do processo de formação acadêmica e/ou profissional, que não termina com a concessão do diploma de graduação (Parecer CNE/CES n 1.133 , grifos nossos).

Para cumprir com essas expectativas, o Parecer CNE/CES n ${ }^{\circ} 1.133$ define como princípios das Diretrizes Curriculares Nacionais:

- Assegurar às instituições de ensino superior ampla liberdade na composição da carga horária a ser cumprida para a integralização dos currículos, assim como na especificação das unidades de estudos a serem ministradas;

- Indicar os tópicos ou campos de estudo e demais experiências de ensino-aprendizagem que comporão os currículos, evitando, ao máximo, a fixação de conteúdos específicos com cargas horárias pré-determinadas, as quais não poderão exceder $50 \%$ da carga horária total dos cursos. A Comissão da CES, baseada neste princípio, admite a definição de percentuais da carga horária para os estágios curriculares nas Diretrizes 
Curriculares da Saúde;

- Evitar o prolongamento desnecessário da duração dos cursos de graduação;

- Incentivar uma sólida formação geral, necessária para que o futuro graduado possa vir a superar os desafios de renovadas condições de exercício profissional e de produção do conhecimento, permitindo variados tipos de formação e habilitações diferenciadas em um mesmo programa;

- Estimular práticas de estudo independente, visando uma progressiva autonomia intelectual e profissional;

- Encorajar o reconhecimento de conhecimentos, habilidades e competências adquiridas fora do ambiente escolar, inclusive as que se referiram à experiência profissional julgada relevante para a área de formação considerada;

- Fortalecer a articulação da teoria com a prática, valorizando a pesquisa individual e coletiva, assim como os estágios e a participação em atividades de extensão;

- Incluir orientações para a conclusão de avaliações periódicas que utilizem instrumentos variados e sirvam para informar às instituições, aos docentes e aos discentes acerca do desenvolvimento das atividades do processo ensino-aprendizagem.

Não presenciamos uma mudança sutil ou de aparência aos processos de formação, conforme aquilo que está proposto e definido formalmente pelas Diretrizes. Ao contrário, trata-se de uma mudança profunda, com grande implicação no modo de ensinar e aprender e no modo de gerir o ensino e a aprendizagem. Portanto, um grande desafio para todos nós que compomos segmentos do trabalho, formação e pesquisa na saúde. Não se trata de tornar o ensino refém do sistema de saúde (invertendo a equação existente até então), mas de constituir relações de pertencimento, com capacidade de construir mudança nos aspectos em que é insuficiente e de produzir conhecimentos úteis e capazes de tornar mais densas as práticas de gestão, cuidado, escuta social e ensino no seu interior. Trata-se do desafio de constituir nas práticas de ensino na saúde a noção de corresponsabilidade com a atenção, com a gestão e com a participação na saúde ${ }^{2}$.

Uma boa evidência do tamanho desse desafio diz respeito às características do trabalhador da saúde que devem ser fomentadas no processo de formação. As normas atuais desprendem-se da proposta de moldar identidades profissionais definidas pelas disciplinas e pelas áreas de conhecimento e apostam radicalmente na interferência recíproca entre a educação (o ensino/ pesquisa) e a saúde (a atenção/gestão). As Diretrizes buscam reformar a articulação entre a Educação Superior e o Sistema de Saúde, com o objetivo de produzir uma

(...) formação geral e específica dos egressos/profissionais com ênfase na promoção, prevenção, recuperação e reabilitação da saúde, indicando as competências comuns gerais para esse perfil de formação contemporânea dentro de referenciais nacionais e internacionais de qualidade (Parecer CNE/CES $n^{\circ} 1.133$ ).

Para fortalecer essa articulação, o Parecer CNE/CES n 1.133 registra alguns conceitos legais de caráter seminal para a saúde, inclusive o conceito ampliado de saúde, as diretrizes do sistema de saúde e alguns principios da regulamentação do setor:

- A saúde é direito de todos e dever do estado, garantido mediante políticas sociais e econômicas que visem à redução do risco de doença e de outros agravos e ao acesso universal e igualitário às ações e serviços para sua promoção, proteção e recuperação (Art. 196 da Constituição Federal de 1988);

2 Essa configuração de implicações reciprocas entre ensino, gestão, atenção e participação foi denominada por Ceccim (CECCIM \& FEUERWERKER, 2004; CECCIM, 2005) como "quadrilátero da formação", é um conceito-chave da Política Nacional de Educação Permanente em Saúde e traz contribuições muito relevantes para pensar na formação dos profissionais de saúde. 
- As ações e serviços públicos de saúde integram uma rede regionalizada e hierarquizada e constituem um sistema único, organizado de acordo com as seguintes diretrizes (Art. 198 da Constituição Federal de 1988):

I - descentralização;

II - atendimento integral, com prioridade para as atividades preventivas, sem prejuízo dos serviços assistenciais;

III - participação da comunidade.

- O conjunto de ações e serviços de saúde, prestados por órgãos e instituições públicas federais, estaduais e municipais, da Administração direta e indireta e das fundações mantidas pelo Poder Público, constitui o Sistema Único de Saúde (SUS). (Art. $4^{\circ}$ da Lei 8.080/90). Parágrafo $2^{\circ}$ deste Art.: A iniciativa privada poderá participar do Sistema Único de Saúde (SUS), em caráter complementar.

- São objetivos do Sistema Único de Saúde (Art. $5^{\circ}$ da Lei 8.080/90):

I - a identificação e divulgação dos fatores condicionantes e determinantes da saúde;

II - a formulação de política de saúde;

III - a assistência às pessoas por intermédio de ações de promoção, proteção e recuperação da saúde, com a realização integrada das ações assistenciais e das atividades preventivas.

- As ações e serviços públicos de saúde e os serviços privados contratados ou conveniados que integram o Sistema Único de Saúde (SUS), são desenvolvidos de acordo com as diretrizes previstas no Art. 198 da Constituição Federal, obedecendo ainda aos seguintes principios (Art. $7^{\circ}$ da Lei 8.080/90):

I - universalidade de acesso aos serviços de saúde em todos os níveis de assistência;

II - integralidade de assistência, entendida como conjunto articulado e contínuo das ações e serviços preventivos e curativos, individuais e coletivos, exigidos para cada caso em todos os niveis de complexidade do sistema;

VII - utilização da epidemiologia para o estabelecimento de prioridades, a alocação de recursos e a orientação programática;

$\mathrm{X}$ - integração em nível executivo das ações de saúde, meio ambiente e saneamento básico;

XII - capacidade de resolução dos serviços em todos os níveis de assistência.

Parece desnecessário para o objetivo deste texto o aprofundamento da discussão sobre cada um desses "disparadores". O que interessa é destacar que a presença nominada e detalhada desses conceitos no Parecer gera a evidência de que eles devem mobilizar e transversalizar toda a formação. Está claro para todos nós que isso não ocorre no conjunto da formação, para o conjunto dos cursos, sequer fazem parte do cotidiano dos docentes e discentes, preservadas as exceções de muitos cursos em diferentes profissões, que gostariam de novos subsídios normativos para preservarem seus esforços criativos. Resta o grande desafio que não pode estar distante de quem quer ensinar: estar aberto à aprendizagem!

Para complementar ainda mais a tendência que está descrita até agora, é importante compreender o que está estabelecido como objeto e como objetivo das Diretrizes Curriculares Nacionais para os cursos da área da saúde. Como objeto das Diretrizes, ficou estabelecido:

(...) permitir que os currículos propostos possam construir perfil acadêmico e profissional com competências, habilidades e conteúdos, dentro de perspectivas e abordagens contemporâneas de formação, pertinentes e compativeis com referencias nacionais e internacionais, capazes de atuar com qualidade, eficiência e resolutividade, no 
Sistema Único de Saúde (SUS), considerando o processo da Reforma Sanitária Brasileira (Parecer CNE/CES n 1.133).

Como objetivo das Diretrizes Curriculares para os cursos da saúde, o Parecer define:

(...) levar os alunos dos cursos de graduação em saúde a aprender a aprender que engloba aprender a ser, aprender a fazer, aprender a viver juntos e aprender a conhecer, garantindo a capacitação de profissionais com autonomia e discernimento para assegurar a integralidade da atenção e a qualidade e humanização do atendimento prestado aos indivíduos, famílias e comunidades (Parecer CNE/CES n 1.133, grifos nossos).

Uma vez mais é preciso registrar duas situações claras: a distância que ainda estamos dessas situações enunciadas e o grande desafio que temos de assimilar esses conceitos e construir tecnologias compativeis com a nossa realidade e capazes de alavancar mudanças no nosso curso na direção apontada pelas normas em vigor. A educação teria de articular a "formação" (construção de modos de ser/estar), a "qualificação" (domínio dos referenciais de intervenção técnico-científica) e, ainda, a "capacidade de interagir" (fazer-se questões permanentemente). A leitura e análise do que se denomina naquele Parecer como "competências e habilidades gerais" nos auxilia na compreensão do campo da saúde como transversalidade às diferentes formações. No caso da reflexão sobre a formação de diretrizes para a graduação em Saúde Coletiva, desafia-nos à constituição de capacidades profissionais específicas, uma vez que é visivel desse "núcleo" uma grande transversalidade nas demais profissões.

Como se viu nas definições do Parecer CNS/CES n $1.133 / 2001$, a formação na área da saúde deve ter como objetivo dotar os profissionais de condições para o desenvolvimento intelectual e profissional autônomo e permanente. As competências e habilidades gerais para a atuação em saúde (ou seja, as condições de ser e estar em equipe, de maneira interdisciplinar e intersetorial) - que os cursos da saúde devem desenvolver - compõem o texto do Art. $4^{\circ}$ da Resolução e estão definidas como:

I - Atenção à saúde: os profissionais de saúde, dentro de seu âmbito profissional, devem estar aptos a desenvolver ações de prevenção, promoção, proteção e reabilitação da saúde, tanto em nível individual quanto coletivo. Cada profissional deve assegurar que sua prática seja realizada de forma integrada e contínua com as demais instâncias do sistema de saúde, sendo capaz de pensar criticamente, de analisar os problemas da sociedade e de procurar soluções para os mesmos. Os profissionais devem realizar seus serviços dentro dos mais altos padrões de qualidade e dos princípios da ética/ bioética, tendo em conta que a responsabilidade da atenção à saúde não se encerra com o ato técnico, mas sim, com a resolução do problema de saúde, tanto em nível individual como coletivo;

II - Tomada de decisões: o trabalho dos profissionais de saúde deve estar fundamentado na capacidade de tomar decisões visando o uso apropriado, eficácia e custo-efetividade, da força de trabalho, de medicamentos, de equipamentos, de procedimentos e de práticas. Para este fim, os mesmos devem possuir competências e habilidades para avaliar, sistematizar e decidir as condutas mais adequadas, baseadas em evidências científicas;

III - Comunicação: os profissionais de saúde devem ser acessíveis e devem manter a confidencialidade das informações a eles confiadas, na interação com outros profissionais de saúde e o público em geral. A comunicação envolve comunicação verbal, não-verbal e habilidades de escrita e leitura; o domínio de, pelo menos, uma língua estrangeira e de tecnologias de comunicação e informação;

IV - Liderança: no trabalho em equipe multiprofissional, os profissionais de saúde de- 
verão estar aptos a assumir posições de liderança, sempre tendo em vista o bem-estar da comunidade. A liderança envolve compromisso, responsabilidade, empatia, habilidade para tomada de decisões, comunicação e gerenciamento de forma efetiva e eficaz;

V - Administração e gerenciamento: os profissionais devem estar aptos a tomar iniciativas, fazer o gerenciamento e administração tanto da força de trabalho quanto dos recursos fisicos e materiais e de informação, da mesma forma que devem estar aptos a serem empreendedores, gestores, empregadores ou lideranças na equipe de saúde; e

VI - Educação permanente: os profissionais devem ser capazes de aprender continuamente, tanto na sua formação, quanto na sua prática. Desta forma, os profissionais de saúde devem aprender a aprender e ter responsabilidade e compromisso com a sua educação e o treinamento/estágios das futuras gerações de profissionais, mas proporcionando condições para que haja beneficio mútuo entre os futuros profissionais e os profissionais dos serviços, inclusive, estimulando e desenvolvendo a mobilidade acadêmico/profissional, a formação e a cooperação por meio de redes nacionais e internacionais. (Resolução CNE/CES n 3/2001).

\section{Desafios para a formação em saúde coletiva no contexto das Diretrizes Cur- riculares Nacionais}

O contexto de emergência e de configuração das diretrizes curriculares para os cursos da área da saúde constituem desafios importantes para as modelagens pedagógicas da formação. Listar-se-á alguns desafios transversais às profissões na saúde.

\section{Conceito ampliado de saúde}

São inúmeras as variações sobre o conceito de saúde que foram sendo construídas nos últimos anos. As diretrizes para a mudança no ensino da saúde apontam o conceito ampliado de saúde, que está registrado na Constituição brasileira de 1988, como o conceito que deve embasar o ensino. Isso significa uma quebra com o conceito utilizado nas vertentes da biopolitica ou medicalização, na oposição entre tratamento e prevenção e na utilização acrítica de conceitos universais e idealizados, como aquele que esteve na base da criação da Organização Mundial da Saúde na metade do século passado, que definiu saúde como o "estado" de "completo bem-estar físico, mental e social". A saúde, no conceito "ampliado", tal como a legislação brasileira assinala, não se trata de "estado", mas uma "situação" a ser analisada.

A saúde configura um processo associado aos modos de andar a vida das pessoas, diz respeito à qualidade de suas vidas, individualmente e nos coletivos de que fazem parte, diz respeito à capacidade que têm de produzir mudanças no cotidiano para torná-lo melhor para se viver, aos mecanismos que utilizamos para lidar com a dor e o sofrimento causados pelas doenças, aos efeitos das políticas sociais no cotidiano privado, institucional ou coletivo e assim, narrativamente, sobre a vida que levamos e nossa potência de criação e vigor. Esse conceito também fala da capacidade que profissionais e serviços de saúde têm para interferir no sentido de aumentar a qualidade da vida em cada contexto singular em que um usuário ou um coletivo expressam necessidades de saúde ${ }^{3}$ e, portanto, de reconhecer essas necessidades para além de sinais e sintomas individuais, convertidos em uma história natural ou patologias descritas na literatura. Uma primeira consequência desse conceito é que o usuário do cuidado não pode mais ser simplesmente um paciente, que recebe passivamente procedimentos, informações e ações assistenciais. Sendo um cidadão, detentor do direito de pedir e receber ações e serviços

3 Sobre as implicações da categoria "necessidades de saúde" no trabalho e no ensino em saúde sugere-se o artigo de Cecílio \& Matsumoto (2006). 
3

que ampliem sua qualidade de vida, precisa ser compreendido na sua integralidade ${ }^{4}$, detentor do direito de ter direitos.

No que se refere à nossa responsabilidade docente de gerir e implementar o ensino das profissões da saúde, esse conceito ampliado de saúde traz profundas implicações. Na análise dos planos de ensino - assim como nas análises em geral sobre o ensino na saúde - o conceito amplamente prevalente ainda é o de uma saúde tomada em sentido negativo, pelos afastamentos de uma norma tomada em referência e que definiria o que e quando é saudável. A doença e seus sintomas ou o "outro" em sua expressão de aflições, sofrimentos ou dores em um portador de anormalidades. O primeiro desafio é produzirmos uma quebra desse conceito na nossa subjetividade, que não é uma tarefa fácil já que o ensino das profissões têm sido há muitos anos todos nós docentes hoje seguramente ainda somos egressos dessa formação - um processo de construção de subjetividades embasado num ideal corporativo e tecnológico de profissão, cuja ação mais legítima é o combate especializado aos sinais, sintomas e doenças.

É preciso destacar que essa postura marca um distanciamento dos valores que "fabricaram" a própria profissão de enfermeiro, médico ou nutricionista, ou seja, de um lugar de diagnosticar e prescrever (sob suas diferentes formas), ao lugar de detectar e construir qualidade de vida e acesso ao cuidado a todo cidadão que dele necessitasse. O segundo grande desafio, uma vez que tivermos conseguido nos desvencilhar da ideia de que o cuidado em saúde é meramente o combate às doenças, é tomarmos, então, a saúde como objeto do cuidado: a saúde como processo complexo, dinâmico e mutável, com características históricas e sociais, com consequências na vida dos indivíduos, como processo subjetivo (relacionado ao plano dos afetos), cujas aflições, dores e sofrimentos têm efeitos particulares na vida de cada um e consequências singulares nos coletivos.

Sem abrir mão de termos grande capacidade de operar com "evidências" no conhecimento e abordagem das doenças, é preciso inserir, de forma substantiva, a capacidade de escuta e geração de práticas com base em mais evidências que aquelas da "biomedicina", isto é, também com aquelas relativas ao conhecimento em humanidades e sociedade, inclusive com profundo respeito à autonomia e à participação do usuário no diagnóstico e prescrição (um processo bastante complexo e bastante mais contemporâneo). Embora a saúde como um todo - ao contrário do "recorte" das doenças bem estruturadas - não seja tão sensivel a receitas e a modelos de abordagem, a transposição do modelo da doença (história natural) para a saúde (história singular) no trabalho de tratar, cuidar e escutar e de ensinar vem sendo feito com as abordagens da Integralidade (LAPPIS), da Promoção da Saúde (Ayres), das Práticas Cuidadoras (Merhy; Franco) ou de uma Clínica Mestiça ou Clínica Híbrida (Ceccim; Ferla; Ceccim \& Ferla), talvez de uma Clínica do Território (Medeiros) ou Clínica da Saúde Coletiva (Ceccim) que procuram destacar a promoção da saúde, associar a promoção à assistência e à reabilitação, entender o cuidado como uma rede de práticas que constituem sistemas de cuidado, compreender o cuidado como um conjunto de práticas embasadas na integralidade.

Parece-nos fundamental que cada professor e cada área busque analisar criticamente o conceito de saúde que está subjacente a seus planos e práticas de ensino e procurem desenvolver estratégias para o conceito ampliado de saúde, contribuindo com ações inovadoras e experiências "atuais". Não há como cuidar das pessoas e suas doenças ou qualidade de vida se não soubermos conhecer e entender a linguagem das sensações, do desejo e dos sintomas.

4 O conceito de integralidade aqui engloba variáveis biológicas, psicológicas, sociais, antropológicas, culturais e subjetivas. O que significa que a compreensão que está registrada inclui a capacidade de escuta qualificada. A expressão "escuta à vida" traduziria operacionalmente esse desafio (CECCIM \& CAPOZZOLO, 2004; FERLA 2007) na medida em que teria a capacidade de perscrutar a complexidade e a produção de subjetividade com pesso-as, coletivos e instituições. Essa escuta e a resposta com base na integralidade somente seriam possiveis com a gestão do cuidado sendo operada radicalmente com tecnologias leves e centrada no usuário (MERHY, 2006). 
Os quadros de adoecimento mais graves hoje em dia não são bem estruturadas (neoplasias, tabagismo, obesidade, diabetes, hipertensão, uso de drogas e Aids, por exemplo) e, mesmo diante de quadros bem estruturados são frequentes o abando do tratamento, a não adesão, a culpabilização e individualização e a "recaída". Uma parcela significativa e crescente da população, como adolescentes e idosos, tem estado fora dos sistemas e serviços de saúde.

\section{Gestão do cuidado e suas tecnologias}

Como consequência da transposição conceitual que foi abordada no item anterior, o cuidado em saúde vem tendo transformações importantes, ainda distantes da maior parte dos processos de formação de profissionais. Nas abordagens mais associadas à racionalidade científica moderna ou "razão médica" (LUZ, 2004), o cuidado em saúde está associado à capacidade de identificar objetivamente as evidências de sinais e sintomas do individuo doente, de classificar essas evidências em doenças e de aplicar as melhores técnicas disponiveis para cada enfermidade/quadro clínico ${ }^{5}$. Essa abordagem normalmente é classificada como centrada na técnica e no procedimento, já que esses são os planos mais relevantes para "gerir" o cuidado. A "decisão" sobre o que deve ou não ser feito é derivada da própria técnica, tendo o profissional a necessidade de deter e operar os conhecimentos mais densos do ponto de vista da "razão médica". Nas novas abordagens, esse conjunto de capacidades é apenas parte do cuidado e, muitas vezes, sequer a parte mais importante, uma vez que os problemas de saúde tendem a ser diferentes das doenças bem estruturadas, cada vez mais de amplo domínio da população e das mídias. Sem problema, espera-se, pois é real a elevação dos saberes científicos de maneira geral em toda a população. Trabalhamos pra isso na universidade com todo tipo de iniciação científica e popularização da ciência.

Existe a necessidade de uma grande mudança na própria compreensão do que seja o cuidado, a gestão da clínica, a análise de situações de saúde, o desenvolvimento de trabalhadores e a avaliação de resultados e satisfação dos usuários. Tendo um conjunto tão ampliado de abordagens (muito além da oferta de procedimentos da "razão médica"), o cuidado em saúde não pode mais ser embasado apenas em conhecimentos da biopolitica/biomedicina e, como consequência, não podemos ter processos de decisão pautados somente pela técnica e pelo próprio conhecimento em condutas, procedimentos e medicamentos. A gestão do cuidado passa a ser uma demanda importante de decisão do profissional, em oposição à aplicação da própria técnica e das "melhores evidências científicas". O profissional precisa ampliar sua capacidade da simples aplicação da técnica para a de "tomar decisões" com base num conjunto complexo de evidências, inclusive da técnica. Assim, a capacidade de gerir a clínica torna-se um problema teórico e prático tanto para o cotidiano dos serviços como para o ensino das profissões.

As abordagens mais recentes e o embasamento das atuais diretrizes de mudança do ensino tomam esse problema propondo compreender o cuidado como processo de trabalho ${ }^{6}$. As-

5 Em natural, racional, social, Madel Luz aborda a racionalidade científica moderna e revela uma "razão médica" em seu desdobramento, dominando o fazer em saúde e os conceitos sobre vida e saúde (LUZ, 2004). Madel Luz desenvolveu o conceito de "racionalidades médicas", localizando a biomedicina, mas também outros "sistemas médicos complexos", como a homeopatia, a medicina tradicional chinesa, medicina ayurveda e a antroposofia, além do conjunto de práticas tradicionais indigenas, africanas e fitoterápicas, complementares, por exemplo (Luz (2005).

6 Emerson Merhy é um dos autores com farta produção nessa abordagem para a área da saúde. Utilizando-se de referenciais teóricos da área das ciências humanas, em particular da analisando práticas do trabalho e de pensamento, esse autor amplia a capacidade de análise sobre o cuidado, sobre as lógicas que procuram organi-zar o cuidado e sobre as tecnologias utilizadas para geri-lo e produzi-lo no cotidiano das instituições. A produção desse autor permite perceber particularidades do trabalho em saúde que as análises embasadas nos refe-renciais mais clássicos da área não identificavam. Para Merhy, o trabalho em saúde é essencialmente criativo e mediado pelas relações entre os trabalhadores e usuários, o que faz com que classifique esse como um "traba-lho vivo em ato". Sobre os principais conceitos dessas análises, ver especialmente Merhy (1997) e Merhy (2002). 
sim compreendido, o problema teórico de como gerir a clínica (e como ensinar a gestão do cuidado) pode ser resolvido, por exemplo, com a identificação de que tipos de tecnologias ${ }^{7}$ são necessárias/ofertadas em cada momento do trabalho e que redes de cuidado são ofertadas (onde estão, como foram distribuídas, como são coordenadas). A singularidade do trabalho em saúde estaria em um conjunto de habilidades e competências dos profissionais (de cada um individualmente e na composição do trabalho em equipes de saúde, assim como no investimento em redes de cuidado) para estabelecer relações singulares e suficientemente fortes com a construção de práticas cuidadoras e promoção da saúde. Assim, teríamos uma política e uma prática de cuidado não mais centrada na técnica, mas centrada no usuário ${ }^{8}$. Os desafios para o ensino compativel com as mudanças acenadas incluem o desenvolvimento da capacidade de escuta, de humanização, da identificação de fatores que condicionam e determinam certas formas de organizar o trabalho de cuidar, de administrar conflitos e divergências de interesses nas práticas de saúde e tomar decisões com base na ideia do direito à saúde do usuário, de analisar os efeitos financeiros e assistenciais das diferentes técnicas de cuidado etc..

\section{Educação Permanente em Saúde como dispositivo para a aprendizagem}

As disposições legais para o ensino estabelecem um conjunto de capacidades para o exercício profissional que são do âmbito da relação entre formação e cotidiano do trabalho. Ao contrário do sentido que se utiliza com alguma frequência, a educação permanente em saúde não significa - a exemplo da educação continuada - a reunião e oferta de metodologias para a renovação de conhecimentos que se especializaram e aprofundaram. Trata-se de um movimento de colocar em análise saberes de que dispomos, estratégias com que os operamos e interrogação sobre aqueles saberes que dos nossos divergem ou os questionam. Cabe à educação permanente perguntar sobre a arquitetura de saberes e todas as formas e colocá-los em prática, de questionar a insuficiência de recursos para sanar problemas práticos e considerar quais atores da prática ou dos saberes, pertencentes às nossas relações, portam outras explicações e outros caminhos e convidar ao engendramento de novidades/desafios.

Não se trata da alocação de técnicas de ensino-aprendizagem, mas de estratégias de pensamento ou de problematização, que fazem emergir situações vividas no cotidiano como saberes tácitos e relevantes, assim como a construção de intervenções inovadoras e produção de arranjos inéditos de conhecimentos e práticas. A educação permanente em saúde, que é também uma política do sistema de saúde, é uma prática de ensino e aprendizagem baseada na "produção de conhecimentos no cotidiano das instituições de saúde, a partir da realidade vivida pelos atores envolvidos, tendo os problemas enfrentados no dia-a-dia do trabalho e as experiências desses atores como base para a interrogação e mudança" (CECCIM \& FERLA, 2006, p. 107).

Para o ensino de graduação, a incorporação da educação permanente em saúde significa utilizar estratégias problematizadoras para o ensino (assim como todas as demais consequências do

\footnotetext{
7 Emerson Merhy (2002) nos alerta de que há uma transposição conceitual corrente que reduz o sentido da expressão "tecnologias" para "equipamentos tecnológicos". O autor propõe uma tipologia operacional que devolve a esse conceito sua abrangência. Assim, classifica como tecnologias duras os equipamentos e outras ferramentas tecnológicas; tecnologias leve-duras os saberes estruturados, como a clínica e a epidemiologia, que frequentemente "disciplinam" as práticas dos profissionais; e as tecnologias leves, que são todos os recursos que entram em cena para produzir a relação que se estabelece entre os sujeitos no momento do cuidado, desde as interações afetivas até as decisões sobre quais ações de cuidado serão ofertadas ao usuário singular que está sendo cuidado.

8 Uma metáfora utilizada por Merhy (2002) provavelmente ajude a compreender de forma adequada esse conceito. O autor propõe que compreendamos as diferentes naturezas tecnológicas armazenadas em diferentes valises: uma valise com as tecnologias duras nas mãos dos profissionais, uma valise com as tecnologias duras na cabeça dos profissionais (os conhecimentos estruturados induzem à decisão) e uma valise com as tecnologias leves, por toda a pele, na relação entre o profissional e o usuário.
} 
conceito de ensino problematizador, inclusive a revisão dos papéis de educadores e educandos e a implicação com os cenários de aprendizagem), assim como buscar a aprendizagem significativa (assentada nas experiências e vivências dos alunos e provocadora da vontade de aprender mais), ou seja, significa produzir estratégias de ensino-aprendizagem embasadas "na produção de conhecimentos que respondam a perguntas que pertencem ao universo de experiências e vivências de quem aprende e que gerem novas perguntas sobre o ser e o atuar no mundo" (CECCIM \& FERLA, 2006, p. 107). Levado à radicalidade indicada nas Resoluções CES/CNS $n^{\circ} 3$, 4 e 5, que apontam o aprender a aprender como uma capacidade do enfermeiro, do médico e do nutricionista, a implicação da educação permanente em saúde no planejamento e na gestão do ensino significa um processo de interrogação constante sobre o ensinar e o aprender, sobre os cenários em que isso se desenvolve e sobre o quanto nossas práticas de ensino devem se distanciar do disciplinamento e alcançar o desafio do pensamento e do desenvolvimento de atitudes críticas e capazes de responsabilização pelo cuidado e pela transformação das condições que afetam a vida.

Não há receitas; precisam existir inquietações. Precisamos nos interrogar constantemente se os cenários e as metodologias utilizadas são os melhores? Se não será possível interagir mais e de forma mais implicada? Se estamos conseguindo obter de nossos planos e práticas de ensino as melhores possibilidades de aprendizagem? Estamos implicados com as aprendizagens, com seu papel na sociedade e na transformação de "estados"? Conseguimos perceber e operar com teoria e prática de forma associada, transversal e não hierarquizada entre subáreas e especialidades de saberes em nossa área? Estamos criando cenários de aprendizagem que possibilitam o desenvolvimento das habilidades e competências necessárias ao exercício no campo e no núcleo de conhecimentos e práticas onde se insere nossa profissão? Estamos formando profissionais capazes de atuar em diferentes contextos e dialogar com diferentes campos e núcleos profissionais? É desse tipo de pergunta que nasce a atualização do trabalho de ensinar.

\section{Campo da saúde e o núcleo de conhecimentos e práticas profissionais da saúde coletiva}

As discussões sobre o campo de conhecimentos da saúde e o núcleo de conhecimentos e práticas de cada profissão e as relações entre esses dois "segmentos" são anteriores à discussão das diretrizes curriculares, entretanto, as diretrizes nacionais - a exemplo do que fazem os documentos básicos da área da saúde há alguns anos - têm, claramente, uma opção política que aponta para a superação da prescrição moderna às profissões, em particular das profissões da saúde, de constituírem identidades profissionais rígidas e, principalmente, em oposição às demais. Do objeto privativo ao objeto de especificidade, do dimensionamento corporativo de profissionais nos serviços ao dimensionamento da construção das respostas demandadas em necessidades de saúde, das fronteiras entre às profissões ao habitar das fronteiras em transição, da preservação dos campos disciplinares à permanente renovação dos saberes-fazeres muito caminho há a percorrer. Enquanto isso, ousamos ou esperamos?

Desde a racionalidade científica moderna, o ensino dos profissionais se confunde com a produção de identidade das profissões e essa transposição transforma a educação em mera formatação de uma "matéria-prima" (aluno), cuja característica principal seria a inexistência ou incipiência de identidade profissional, em protótipos profissionais ("recurso humano especializado"), certificados por instituição de ensino e chancelados por órgãos de fiscalização do exercício profissional. Dessa maneira, o conceito de campo de conhecimentos que caracteriza a saúde fica subjugado pelo conceito de núcleos de identidade profissional e, de certa forma, de- 
saparecendo na soma desses, uma vez que não se trata de justaposição, mas complexificação. A tentativa recente é de inversão desse paradigma, colocando em análise a contribuição efetiva de cada profissão para o campo da saúde. Essa inversão traz fortes consequências para o ensino, entre elas a fragmentação ou o trabalho em equipes multiprofissionais e interdisciplinares. Esse movimento requer uma grande reflexão de cada instituição de ensino, cada curso, cada plano de ensino, cada professor, cada unidade de produção pedagógica professor-alunos sobre o quanto e como dilatar as fronteiras das experiências de ensino, ampliar a permeabilização de fronteiras, aceitar o desmanchamento e refazimento permanente de fronteiras.

As bases legais arroladas para a estruturação do curso da Análise de Políticas e Sistemas de Saúde - Bacharelado em Saúde Coletiva, na Universidade Federal do Rio Grande do Sul, curso sem diretrizes curriculares nacionais, foram a chancela da Lei de Diretrizes e Bases da Educação Nacional para a organização de cursos experimentais, desde que obedecidas as disposições da Lei (LDB, Art. 81), correlacionando-o com as Diretrizes Curriculares Nacionais dos cursos de graduação da área da saúde, conforme Edital da SESu/MEC $n^{\circ} 4$, de 10/12/1997, atendendo ao Parecer CNS/CES n ${ }^{\circ}$ 583, de 04/04/2001 e aos determinantes da Constituição Federal de 1998 (Art. 200, 205, 208 e 214), Lei Federal n 8.080, de 19/09/1990 (Art. 13, 14, 15 e 27) e Lei Federal n 9.394, de 20/12/1996 (Art. $1^{\circ}, 2^{\circ}, 3^{\circ}, 43$ e 53). Quanto à atuação profissional, foi considerada a família 2033-20, da Classificação Brasileira de Ocupações (CBO), designada por Pesquisador em Saúde Coletiva, a quem compete:

1. Desenvolver pesquisas em ciências da saúde

Analisar resultados

Aplicar métodos e procedimentos

Avaliar tecnologia aplicada à área

Coletar dados de pesquisa

Desenvolver tecnologia aplicada à área

Executar projeto piloto

Monitorar desenvolvimento da pesquisa

Organizar bancos de dados

Produzir produtos e processos

Recrutar sujeitos de pesquisa

Selecionar amostra de pesquisa

2. Divulgar resultados e informações

Apresentar trabalhos científicos

Conceder entrevistas

Organizar eventos

Produzir material educativo

Produzir material técnico-científico

Proferir palestras

Submeter trabalhos para publicação

3. Elaborar projetos de pesquisa em ciências da saúde

Analisar bibliografia

Definir cronograma físico e financeiro de execução de pesquisa

Definir metodologia

Definir objetivos de pesquisa

Definir objeto de pesquisa

Elaborar justificativa de desenvolvimento de pesquisa

Redigir projeto de pesquisa

Submeter projeto à aprovação institucional 
Submeter projeto à aprovação junto ao comitê de ética

4. Planejar projetos e pesquisas em ciências da saúde

Avaliar viabilidade econômica

Avaliar viabilidade técnica e de pessoal

Captar recursos financeiros

Detectar demandas de mercado

Diagnosticar necessidades sanitárias

Identificar parceiros e colaboradores

Levantar demandas científicas

5. Capacitar recursos humanos em ciências da saúde

Ministrar aulas

Organizar cursos

Orientar técnicos e profissionais

Orientar trabalhos acadêmicos

Selecionar recursos humanos

Treinar equipe de pesquisa e profissionais da área de saúde

6. Prestar serviços de extensão na área de saúde

Emitir laudos e pareceres técnico-científicos

Orientar ações de saúde voltadas para politicas públicas

Orientar politicas públicas na área da saúde

Prestar assessorias e consultorias

Prestar assistência comunitária

Realizar diagnósticos e vistorias na área de saúde

7. Comunicar-se

Desenvolver compreensão de linguagem corporal

Desenvolver expressão escrita

Desenvolver expressão oral

Trabalhar em equipe

8. Demonstrar competências pessoais

Atualizar-se na profissão

Demonstrar altruísmo

Demonstrar flexibilidade

Demonstrar persistência

Demonstrar perspicácia

Desenvolver capacidade de concentração

Evidenciar atenção para detalhes

Evidenciar objetividade

Trabalhar com organização

Foram objetivos do curso de graduação e previsão do perfil do egresso:

- Formar profissionais para analisar crítica e propositivamente as políticas de saúde com elevado padrão de qualidade e dentro dos princípios da ética e da bioética, com senso de responsabilidade social e compromisso com a cidadania, a partir do contexto político-normativo do SUS, bem como para constituir condições para a implementação e avaliação dessas políticas, ou seja, um sanitarista generalista;

- Formar sanitaristas adequados às demandas do Sistema Único de Saúde, fortalecendo a descentralização da gestão, a democratização do processo decisório, a integralidade da atenção à saúde e a participação popular no âmbito dos sistemas e serviços de saúde; 
- Formar sanitaristas para uma prática integrada e contínua junto às instâncias do Sistema Único de Saúde, sendo capaz de desenvolver processos de planejamento, gestão e avaliação em saúde;

- Formar sanitarista para atuar, direta ou indiretamente, pela promoção, vigilância e educação da saúde, individual e coletiva, garantindo atenção integral à saúde da população.

As competências e habilidades gerais do bacharel em saúde coletiva deveriam guardar similaridade com o grupo de profissões da área da saúde, enquanto as específicas referir-se-iam à formação do Analista de Politicas e Sistemas de Saúde/Sanitarista. A formação do Analista de Políticas e Sistemas de Saúde/Sanitarista replica o Art. $4^{\circ}$ das Resoluções CES/CNE $n^{\circ} 3,4$ e 5 , já citadas neste texto. A formação do Sanitarista teria por objetivo dotar o profissional dos conhecimentos requeridos para o exercício das seguintes competências e habilidades gerais:

I - Atenção à Saúde: o profissional deve estar apto a desenvolver ações de promoção, vigilância e educação da saúde que integrem, complementem ou acrescentem qualidade à atenção integral em saúde, sendo capaz de analisar problemas em saúde coletiva, pensálos criticamente e apresentar proposições no âmbito dos Planos e Programas de Saúde Pública, da Formação e da Educação Permanente em Saúde e da Gestão e Participação no Setor da Saúde, tendo em conta que o compromisso, a responsabilidade e a implicação ética com a saúde não se encerra com o ato técnico-profissional, mas com a resolução dos problemas de saúde; (único campo que se diferencia/singulariza ante as Diretrizes dos demais cursos da área da saúde)

II - Tomada de Decisões: o trabalho do profissional deve estar fundamentado na capacidade de tomar decisões mediante análise de situações de saúde, avaliação de eficácia e custo-efetividade, análise de processos institucionais da força de trabalho, gestão de insumos e tecnologias e organização de processos e práticas;

III - Comunicação: o profissional deve ser acessivel e deve manter a confidencialidade ética e bioética das informações que lhe forem confiadas na interação com outros profissionais de saúde e com o público em geral, envolvendo comunicação verbal e não-verbal e habilidades de escrita e leitura, bem como o domínio de pelo menos uma língua estrangeira e de tecnologias de comunicação e informação;

IV - Liderança: no trabalho em equipe multiprofissional de saúde, o profissional deve estar apto a assumir posições de liderança sob o enfoque da proteção da saúde e dos interesses públicos, envolvendo compromisso, responsabilidade e implicação ética para com a tomada de decisões, comunicações e gerenciamento de forma efetiva e eficaz;

V - Administração e Gerenciamento: o profissional deve estar apto a tomar iniciativas, estabelecer apreciações, apresentar proposições e construir estratégias de acompanhamento e coordenação no âmbito das ações, serviços, sistemas e redes de saúde, organizando, dirigindo e executando processos institucionais de planejamento, gestão e avaliação tanto da força de trabalho, quanto dos recursos físicos, materiais e de informação, bem como devem estar aptos a serem empreendedores, gestores, empregadores ou lideranças nas organizações de saúde;

VI - Educação Permanente: o profissional deve ser capaz de aprender continuamente, tanto na sua formação, quanto na sua prática, envolvendo aprender a aprender, ter responsabilidade e compromisso com a sua educação e a formação das futuras gerações profissionais, proporcionando condições para que haja beneficio mútuo entre estudantes da área da saúde e profissionais do planejamento, gestão e avaliação ou da promoção, vigilância e educação da saúde, inclusive estimulando a mobilidade acadêmico/profissional, a formação e o desenvolvimento por meio de redes nacionais e internacionais. (Projeto Pedagógico de Curso, 2008) 
Quanto às competências e habilidades específicas, conhecimentos e práticas de núcleo profissional, seguiu-se a mesma "matriz" do Artigo $5^{\circ}$ e seu Parágrafo Único. A formação do Analista de Políticas e Sistemas de Saúde/Sanitarista teria por objetivo dotar o profissional do conhecimento requerido para o exercício das seguintes competências e habilidades especificas:

I - atuar profissionalmente, compreendendo a saúde coletiva em suas dimensões e expressões e suas áreas de domínio no conhecimento específico de saúde, orientando-se pela subárea da Saúde Pública;

II - compreender o setor da saúde no contexto das políticas e das práticas sociais, reconhecendo os perfis epidemiológico, demográfico e cultural das populações;

III - estabelecer relações de análise e implicação ética com o controle social, reconhecendo a estrutura e as formas de organização social, suas transformações e expressões;

IV - reconhecer a saúde como direito a condições dignas de vida e atuar de forma a garantir acesso às ações e serviços de saúde, integralidade da atenção e resolutividade das práticas de proteção da saúde;

V - ser capaz de analisar situações de saúde; organizar, dirigir e implementar atividades referentes à formulação e execução de politicas institucionais de planejamento, gestão e avaliação em saúde e políticas protetoras de promoção, vigilância e educação da saúde;

VI - atuar nos diferentes cenários de prática do planejamento, gestão e avaliação e de promoção, vigilância e educação da saúde, considerando os pressupostos da abordagem em saúde coletiva;

VII - identificar necessidades em saúde, seus determinantes e condicionamentos, segundo os padrões epidemiológicos, demográficos, culturais e socioeconômicos;

VIII - implementar atividades de planejamento, gestão e avaliação de ações, programas, serviços, sistemas e redes de saúde;

IX - implementar atividades de planejamento financeiro; elaboração e execução orçamentária; controle da situação financeira e patrimonial; controle contábil-financeiro; liberação de recursos; análise e aprovação de prestações de contas;

$\mathrm{X}$ - implementar atividades de gestão do trabalho e do desenvolvimento de trabalhadores da saúde;

XI - implementar atividades de gestão de materiais, de recursos informatizados e do processo produtivo;

XII - implementar atividades de organização e realização de licitações;

XIII - implementar atividades de realização de pesquisas de mercado e de impacto à saúde;

XIV - implementar atividades de apoio no desenvolvimento mercadológico de novos programas e de resposta às necessidades em saúde;

XV - implementar atividades de divulgação e promoção dos programas e atividades dos sistemas e serviços de saúde;

XVI - participar da composição das estruturas-meio, consultivas e deliberativas do sistema de saúde e das estruturas-fim de atenção à saúde segundo a subárea de conhecimento da Saúde Pública;

XVII - assessorar órgãos, empresas e instituições em planejamento de saúde;

XVIII - conhecer os princípios de metodologia científica na subárea da Saúde Pública, possibilitando-lhe a leitura crítica da informação técnico-científica e a participação na produção de conhecimento; 
XIX - desenvolver, participar e aplicar pesquisas e/ou outras formas de produção de conhecimento que objetivem a qualificação da prática profissional;

XX - lidar criticamente com a dinâmica do mercado de trabalho e com as políticas de saúde;

XXI - interferir na dinâmica do trabalho institucional, reconhecendo-se como agente crítico e ativo deste processo;

XXII - assumir compromisso ético, político e social com o trabalho multiprofissional e interdisciplinar em saúde;

XXIII - implementar atividades de comunicação interna e externa;

XXIV - executar demais atividades definidas em normas dos sistemas e serviços de saúde.

Obs.: A formação do sanitarista, em todos os aspectos das competências e habilidades específicas, deverá contemplar a forte apropriação do Sistema Único de Saúde, sua história, diretrizes e principios; a integralidade da atenção na luta pelo acolhimento, responsabilidade com a resolutividade das instâncias de atendimento e desenvolvimento da autonomia dos usuários; e o trabalho em equipe de saúde. (Projeto Pedagógico de Curso, 2008)

A formação do generalista da saúde coletiva não dispensará a formação de especialistas, mestres e doutores na área, apenas antecipará a oferta desse trabalhador aos serviços e sistemas de saúde. Entre as especialidades da área estão conhecimentos e práticas em vigilância em saúde (vigilâncias epidemiológica, sanitária, ambiental ou de saúde do trabalhador e/ou saúde e ambiente); administração e/ou gerência de sistemas e/ou serviços de saúde; gestão do trabalho e/ou da educação na saúde; avaliação de políticas e/ou programas e/ou de tecnologias em saúde; economia da saúde; direito sanitário; educação em saúde e promoção da saúde, entre vários outros.

\section{Conclusão}

A demanda pela formação do sanitarista não é nova, pode-se dizer que estava projetada desde a criação do Departamento Nacional de Saúde Pública, pelo Decreto Federal n 3.987, de 2 de janeiro de 1920. O Decreto reorganizou os serviços de saúde pública no Brasil. O Presidente da Republica dos Estados Unidos do Brasil decretou e sancionou a criação do Departamento Nacional de Saúde Pública, órgão subordinado diretamente ao Ministro da Justiça e dos Negócios Interiores. A data registra a Reforma Sanitária de Carlos Chagas, ficando reconhecida e instituída a necessidade de caracterizar e monitorar o estado de saúde da população, identificar as suas necessidades em saúde, programar e organizar ações de vigilância da saúde e avaliar o impacto na saúde da população dos riscos de doença e outros agravos de forma a garantir adequação das políticas públicas de saúde às necessidades e a sua efetividade.

Desde aquela data é reconhecida a necessidade do trabalho de um segmento profissional específico, teriam de ser formados, empregados, incentivados à pesquisa, necessariamente considerados na tomada de decisões em saúde pública, cumprindo ações "de natureza agressiva ou defensiva" que tivessem por fim a proteção da saúde, devendo ser priorizado na coordenação das ações de politica sanitária. O sanitarista à época era fundamentalmente médico ou engenheiro, a saúde pública sua especialidade. Oswaldo Cruz introduziu o reconhecimento da área profissional e Carlos Chagas a necessidade de formação profissional e incorporação ao trabalho.

Desde 1982, é a área de saúde coletiva que consta na Tabela de Áreas do Conhecimento, sendo a Epidemiologia, Medicina Preventiva e Social e a Saúde Pública subáreas. Desde 1979, existe a Associação Brasileira de Saúde Coletiva (Abrasco), dedicada ao abrigo da área científica 
e dos profissionais com pós-graduação em suas subáreas e especialidades. Desde 2011, foi criado o Fórum de Graduação em Saúde Coletiva nesta entidade e, em 2012, foi modificado o estatuto da entidade para incluir, como categorias de sócios, os pós-graduados ou pós-graduandos e os graduados ou graduandos em saúde coletiva.

Existem hoje pelo menos 2 cursos por região política do Brasil, os primeiros egressos já se encontram empregados, cursando residência multiprofissional, especialização e mestrado. A partir de 2013, o Conselho Nacional de Educação assumiu o compromisso com o debate das Diretrizes Curriculares Nacionais em Saúde Coletiva, tendo em vista o desencadeamento do processo de reconhecimento de curso. Na Universidade Federal do Rio Grande do Sul, o curso foi criado em 2008, tendo seu primeiro ingresso de alunos em 2009 e a primeira formatura em 2013. O amadurecimento do curso é tarefa de seus docentes, discentes, egressos e dirigentes institucionais, estando em construção permanente.

\section{Referências Bibliográficas}

CECCIM RB. Educação permanente em saúde: desafio ambicioso e necessário. Interface - comunicação, saúde, educação, v. 9, n. 16, p. 161-77, set. 2004/fev. 2005.

CECCIM RB; CAPOZZOLO AA. Educação dos profissionais de saúde e afirmação da vida: a prática clínica como resistência e criação. In: JJN Marins \& cols. (org.). Educação médica em transformação: instrumentos para a construção de novas realidades. São Paulo: Hucitec, 2004, p. 346-390.

CECCIM RB; FERLA AA. Educação permanente em saúde. In: Escola Politécnica de Saúde Joaquim Venâncio (Org.). Dicionário da educação profissional em saúde. Rio de Janeiro: Fiocruz, 2006, p.162-168.

CECCIM RB; FEUERWERKER LCM. O quadrilátero da formação para a área da saúde: ensino, gestão, atenção e controle social. Physis - revista de saúde coletiva, v. 14, n. 1, p. 41-65, 2004.

CECÍLIO LCO; MATSUMOTO NF. Uma taxonomia operacional de necessidades de saúde. In: R Pinheiro; AA Ferla; RA MATTOS (Org.). Gestão em redes: tecendo os fios da integralidade em saúde. Rio de Janeiro: Abrasco; Caxias do Sul: Educs, 2006, p. 37-50.

FERLA AA. Clínica em movimento: cartografia do cuidado em saúde. Caxias do Sul: Educs, 2007.

FERLA AA; LEAL MB; PINHEIRO R. Um olhar sobre práticas avaliativas em descentralização do sistema de saúde: construindo uma abordagem analítica para atuação em rede. In: R Pinheiro; RA Mattos (org.). Gestão em redes: práticas de avaliação, formação e participação em saúde. Rio de Janeiro: Abrasco, 2006, p. 35-60.

FERLA AA; POSSA LB; LEAL MB; VALÉRIO AG; CLAUS SM. Descentralização e políticas públicas para DST/AIDS: estudo do sistema de saúde no Estado do Rio de Janeiro. Rio de Janeiro: Abia, 2006.

LUZ MT. Novos saberes e práticas em saúde coletiva: estudo sobre racionalidades médicas e atividades corporais. 2 ed. São Paulo: Hucitec, 2005.

LUZ MT. Natural, racional, social: razão médica e racionalidade científica moderna. 2 ed. São Paulo: Hucitec, 2004.

MERHY EE. Integralidade: implicações em xeque. In: R PINHEIRO; AA FERLA; RA MATTOS (org.). Gestão em redes: tecendo os fios da integralidade em saúde. Rio de Janeiro:Abrasco; Caxias do Sul: Educs, 2006, p. 97-109.

MERHY EE. Saúde: cartografia do trabalho vivo. São Paulo: Hucitec, 2002.

MERHY EE. Em busca do tempo perdido: a micropolítica do trabalho vivo em saúde. In: EE MERHY; R ONOCKO (org.). Agir em saúde: desafio para o público. São Paulo: Hucitec, 1997, p. 71-112.

PINHEIRO R; FERLA AA; SILVA Jr AG. A integralidade na atenção à saúde da população. In: JJN MARINS \& cols. (org.). Educação médica em transformação: instrumentos para a construção de novas realidades. São Paulo: Hucitec, 2004, p. 269-284. 


\section{ANEXO}

\section{Lista de Documentos das Diretrizes Curriculares Nacionais - Cursos de inter- esse da Saúde}

\section{1) Utilizadas no texto} Enfermagem

- Parecer CNE/CES no 1.133, de 7 de agosto de 2001 Diretrizes Curriculares Nacionais dos Cursos de Graduação em Enfermagem, Medicina e Nutrição.

- Resolução CNE/CES no 3, de 7 de novembro de 2001 Institui Diretrizes Curriculares Nacionais do Curso de Graduação em Enfermagem

\section{Medicina}

- Parecer CNE/CES no 1.133, de 7 de agosto de 2001 Diretrizes Curriculares Nacionais dos Cursos de Graduação em Enfermagem, Medicina e Nutrição

- Resolução CNE/CES no 4, de 7 de novembro de 2001 Institui Diretrizes Curriculares Nacionais do Curso de Graduação em Medicina

- Parecer CNE/CES no 236/2007, aprovado em 8 de novembro de 2007 Alteração do $\S 2^{\circ}$ do art. 7ำ da Resolução CNE/CES no 4/2001, que institui Diretrizes Curriculares Nacionais do Curso de Graduação em Medicina

- Parecer CNE/CES no 241/2008, aprovado em 6 de novembro de 2008 Alteração da expressão "unidade federativa" utilizada no § 2o do art. 7o da Resolução CNE/ CES no 4/2001, que institui Diretrizes Curriculares Nacionais do Curso de Graduação em Medicina

\section{Nutrição}

- Parecer CNE/CES no 1.133, de 7 de agosto de 2001

Diretrizes Curriculares Nacionais dos Cursos de Graduação em Enfermagem, Medicina e Nutrição

- Resolução CNE/CES no 5, de 7 de novembro de 2001

Institui Diretrizes Curriculares Nacionais do Curso de Graduação em Nutrição

\section{2) Integralizadoras da Área da Saúde, conforme Tabela Capes \\ Fisioterapia}

- Parecer CNE/CES no 1210, de 12 de setembro de 2001

Diretrizes Curriculares Nacionais dos Cursos de Graduação em Fisioterapia, Fonoaudiologia e Terapia Ocupacional

- Resolução CNE/CES no 4, de 19 de fevereiro de 2002

Institui Diretrizes Curriculares Nacionais do Curso de Graduação em Fisioterapia

Fonoaudiologia

- Parecer CNE/CES no 1210, de 12 de setembro de 2001

Diretrizes Curriculares Nacionais dos Cursos de Graduação em Fisioterapia, Fonoaudiologia e Terapia Ocupacional

- Resolução CNE/CES no 5, de 19 de fevereiro de 2002

Saúde Coletiva Institui Diretrizes Curriculares Nacionais do Curso de Graduação em Fonoaudiologia.

- Curso sem Diretrizes Curriculares Nacionais (2008-2013)

- Projeto de Diretrizes Curriculares Nacionais do Curso de Graduação em Saúde Coletiva em discussão no CNE (2013)

\section{Terapia Ocupacional}

- Parecer CNE/CES n.․ 1.210, de 12 de setembro de 2001

Diretrizes Curriculares Nacionais dos Cursos de Graduação em Fisioterapia, Fonoaudiologia e Terapia Ocupacional

- Resolução CNE/CES № 6, de 19 de fevereiro de 2002

\section{Farmácia}

Institui Diretrizes Curriculares Nacionais do Curso de Graduação em Terapia Ocupacional

- Parecer CNE/CES no 1.300, de 6 de novembro de 2001

Diretrizes Curriculares Nacionais dos Cursos de Graduação em Farmácia e Odontologia

- Resolução CNE/CES no 2, de 19 de fevereiro de 2002 
Odontologia

Institui Diretrizes Curriculares Nacionais do Curso de Graduação em Farmácia

- Parecer CNE/CES no 1.300, de 6 de novembro de 2001

Diretrizes Curriculares Nacionais dos Cursos de Graduação em Farmácia e Odontologia

- Resolução CNE/CES no 3, de 19 de fevereiro de 2002

Institui Diretrizes Curriculares Nacionais do Curso de Graduação em Odontologia

\section{Educação Física}

- Parecer CNE/CES no 138, de 3 de abril de 2002

Diretrizes Curriculares Nacionais do Curso de Graduação em Educação Física

- Parecer CNE/CES no 58, de 18 de fevereiro de 2004

Diretrizes Curriculares Nacionais para os cursos de Graduação em Educação Física.

- Resolução CNE/CES no 7, de 31 de março de 2004

Institui as Diretrizes Curriculares Nacionais para os cursos de Graduação em Educação Física, em nível superior de graduação plena

- Parecer CNE/CES no 142/2007, aprovado em 14 de junho de 2007

Alteração do § 3ㅇ do art. 10 da Resolução CNE/CES no 7/2004, que institui as Diretrizes Curriculares Nacionais para os cursos de Graduação em Educação Física, em nível superior de graduação plena.

- Resolução CNE/CES no 7, de 4 de outubro de 2007

Altera o \& 3이 do art. 10 da Resolução CNE/CES no 7/2004, que institui as Diretrizes Curriculares Nacionais para os cursos de Graduação em Educação Física, em nível superior de graduação plena.

- Parecer CNE/CES no 274/2011, aprovado em 6 de julho de 2011 - Indicação referente à revisão do texto das Diretrizes Curriculares Nacionais para curso de Graduação em Educação Física

\section{3) Profissão regulamentada como Área da Saúde Biomedicina \\ - Parecer CNE/CES no 104, de 13 de março de 2002 \\ Aprova as Diretrizes Curriculares Nacionais do Curso de Graduação em Biomedicina \\ - Resolução CNE/CES n² 2, de 18 de fevereiro de 2003 \\ Institui as Diretrizes Curriculares Nacionais do Curso de Graduação em Biomedicina}

\section{4) Domínios conexos das Áreas de Ciências Humanas, Agrárias e Sociais Aplicadas Psicologia}

- Parecer CNE/CES n.- 1.314, de 7 de novembro de 2001

Diretrizes Curriculares para o Curso de Graduação em Psicologia

- Parecer CNE/CES n.․ 72, de 20 de fevereiro de 2002

Retificação do Parecer CNE/CES de 1.314/2001 relativo às Diretrizes Curriculares Nacionais para os cursos de Graduação em Psicologia

- Parecer CNE/CES n 62, de 19 de fevereiro de 2004

Diretrizes Curriculares Nacionais para os cursos de Graduação em Psicologia

- Resolução CNE/CES № 8, de 7 de maio de 2004

Institui Diretrizes Curriculares Nacionais do curso de Graduação em Psicologia

- Parecer CNE/CES no 338/2009, aprovado em 12 de novembro de 2009

Aprecia a Indicação CNE/CES no 2/2007, que propõe a alteração do art. 13 da Resolução CNE/ CES no 8, de 7 de maio de 2004, que institui as Diretrizes Curriculares Nacionais para os cursos de Graduação em Psicologia

- Resolução CNE/CES no 5, de 15 de março de 2011 - Institui as Diretrizes Curriculares Nacionais para os cursos de graduação em Psicologia, estabelecendo normas para o projeto pedagógico

Medicina Veterinária complementar para a Formação de Professores de Psicologia

- Parecer CNE/CES no 105, de 13 de março de 2002

Diretrizes Curriculares Nacionais do Curso de Graduação em Medicina Veterinária

- Resolução CNE/CES no 1, de 18 de fevereiro de 2003

Institui Diretrizes Curriculares Nacionais dos Cursos de Graduação em Medicina Veterinária.

\section{Serviço Social}

- Parecer CNE/CES n.․ 492, de 3 de abril de 2001

Aprova as Diretrizes Curriculares Nacionais dos cursos de Arquivologia, Biblioteconomia, Ciências Sociais - Antropologia, Ciência Política e Sociologia, Comunicação Social, Filosofia, Geografia, História, Letras, Museologia e Serviço Social

- Parecer CNE/CES n.ำ 1.363, de 12 de dezembro de 2001 
Retifica o Parecer CNE/CES n. 492, de 3 de abril de 2001, que aprova as Diretrizes Curriculares Nacionais dos cursos de Arquivologia, Biblioteconomia, Ciências Sociais - Antropologia, Ciência Política e Sociologia, Comunicação Social, Filosofia, Geografia, História, Letras, Museologia e Serviço Social

- Resolução CNE/CES no 15, de 13 de março de 2002

Estabelece as Diretrizes Curriculares para os cursos de Serviço Social 



\section{CURSO DE ANÁLISE DE POLÍTICAS E SISTEMAS DE SAÚDE: DETALHAMENTO DO PROJETO PEDAGÓGICO}

\section{DETALHAMENTO DO PROJETO PEDAGÓGICO}

\section{Contexto Educacional}

O Curso de Graduação em Análise de Políticas e Sistemas de Saúde - Bacharelado em Saúde Coletiva, na UFRGS, surge como uma proposta de contribuir para a definição de uma formação inovadora, fundamentalmente contemporânea, de habilitação de profissionais da área da saúde ou com forte atuação desta área de conhecimento no âmbito intersetorial. Nesse sentido, visa amparar o setor de políticas públicas da saúde e a área de conhecimento das ciências da saúde com a formação de um profissional demandado, mas inexistente no âmbito da graduação. Busca, de modo especial, a construção da integralidade e da intersetorialidade nas atividades de coordenação institucional de ações, planos, programas, serviços, sistemas e redes de saúde e de participação na promoção e proteção da saúde das pessoas e coletividades.

A criação do curso Bacharelado em Saúde Coletiva, na Universidade Federal do Rio Grande do Sul, é resultado do movimento de implantação das Diretrizes Curriculares Nacionais para a área da saúde (Edital SESu/MEC n 4, de 10/12/1997 e Resoluções CNE/CES nos 3, 4 e $5 / 2001 ; 2,3,4,5$ e 6/2002; 1 e 2/2003 e 7 e 8/2004) e das Diretrizes Constitucionais Nacionais para o setor da saúde (Artigos 200, 205, 208 e 214, da Constituição Federal de 1988) e seus desdobramentos na Lei de Diretrizes e Bases da Educação Nacional (Artigos $1^{\circ}, 2^{\circ}, 3^{\circ}$, 43 e 53) e na Lei Orgânica da Saúde (Artigos 13, 14, 15 e 27), além do conseqüente processo de mudança nos cursos da área.

Além da UFRGS, outras dezoito (18) Instituições Federais de Ensino Superior (IFES) propuseram, simultaneamente, a criação de curso similar ao proposto pela Escola de Enfermagem. O profissional formado no Bacharelado em saúde Coletiva, atende às funções de analista no amplo setor da saúde sanitarista, por isso o nome proposto ao curso de graduação abrange políticas da concepção à avaliação e meta-avaliação, sistemas, ações, serviços e modelo assistencial. O profissional sanitarista é pensado no âmbito da condução e regulação, onde se inclui "planejamento, gestão e avaliação em saúde" e das ações coletivas de proteção à saúde onde se inclui "educação, promoção e vigilância da saúde" além das ações sociais de participação popular e controle social em saúde.

No que se refere à área de conhecimento do curso, a mesma foi definida na árvore das áreas de conhecimento da Capes, como área da Saúde Coletiva, área que abrange os domínios do Planejamento, Gestão e Avaliação em Saúde e da Educação, Promoção e Vigilância da Saúde.

Outros domínios são emergentes como a Ciência, Tecnologia, a Inovação e a Saúde Ambiental. No Brasil, o profissional em saúde coletiva é designado por Sanitarista, título atualmente utilizado por todos os egressos da especialização em saúde coletiva e suas subáreas ou campos de domínio. Considerado esse conjunto de argumentos e a análise do cenário nacional, entendemos que a titulação do profissional que atende à necessidade da análise de políticas e sistemas de saúde deva ser a de profissional de saúde coletiva, ou seja: Bacharel em Saúde Coletiva. 
O curso de Bacharelado em Saúde Coletiva propõe-se a formar, por meio do embasamento teórico e experiência prático-aplicativa, profissionais voltados para a análise crítica e propositiva de realidades e, a partir destas, venha estabelecer objetivos e metas para o planejamento, gestão e avaliação de políticas e sistemas de saúde e para a educação, promoção e vigilância da saúde, tanto nas áreas específicas de Planos e Programas de Serviços e Produtos e de Organizações e Instituições de Saúde, como na área ampla do desenvolvimento de politicas públicas e de ações coletivas de redução de riscos de doença e outros agravos, e no estabelecimento de condições que assegurem acesso igualitário e universal à promoção, proteção e reabilitação da saúde (CF, Art. 196).

\section{Políticas Institucionais no Âmbito do Curso}

A UFRGS tem uma trajetória centenária no oferecimento de cursos na área da saúde, que tem suas origens na criação da Escola de Farmácia (1896) e de Escola de Partos (1897), seguidas ela criação das Escola de Medicina, Odontologia e Obstetrícia (1898). A Escola de Enfermagem possui e implementa os cursos de bacharelado e licenciatura em enfermagem há quase 60 anos. Hoje, a UFRGS oferece os cursos de Biologia, Biomedicina, Educação Física, Enfermagem, Farmácia, Fonoaudiologia, Medicina, Medicina Veterinária, Nutrição, Odontologia e Psicologia, Serviço Social, além do desenvolvido domínio de conhecimento da Educação em Saúde, na Faculdade de Educação, onde ocorrem os estágios de docência dos cursos de licenciatura da área da saúde e onde está instalado a Residência Integrada Multiprofissional em Saúde Mental Coletiva.

De acordo com o Plano de Desenvolvimento Institucional da UFRGS - 2011/2015, a direção para o próximo período é de buscar a "excelência na contribuição da Universidade para o desenvolvimento da Sociedade e sua responsabilidade em manter-se inserida em sua comunidade, atuando como fator de propulsão de seu desenvolvimento" (Pág. 06). Um curso de formação de sanitaristas representa e fortalece essa opção estratégica da UFRGS, quer pela relevância social da qualificação do sistema de saúde brasileiro, quer pelo fato de que o complexo produtivo da saúde mobiliza recursos em tal vulto que tornam a área da saúde responsável por uma parcela importante do Produto Interno Bruto do país, da Região Sul e do Estado do Rio Grande do Sul, a exemplo também do que ocorre em outros países com os quais a Universidade mantém linhas de cooperação que incluem a área da saúde. A formação de novos profissionais para atuação diferenciada no sistema de saúde em atividades não relacionadas diretamente à clínica e ao cuidado representa reivindicação social e aposta na capacidade de qualificar o Sistema Único de Saúde (SUS) e projetá-lo para os desafios dos próximos anos pelo reconhecimento da complexidade do trabalho no seu interior, que reivindica novas habilidades profissionais. Ainda de acordo com o PDI, essa aposta se traduz na definição de que o desenvolvimento acadêmico se alicerce na oferta de cursos de graduação com qualidade, capazes de atender às demandas da sociedade e também promover a projeção de futuro.

O Curso de Análise de Políticas e Sistemas de Saúde - Bacharelado em Saúde Coletiva, e outros cursos criados recentemente em turno noturno, busca inovações curriculares, integração com outras áreas do conhecimento, constituindo áreas interdisciplinares e integração entre diferentes unidades acadêmicas, em sintonia com o Plano de Desenvolvimento Institucional da UFRGS para o período de 2011/2015. O Bacharelado em Saúde Coletiva, além de representar aumento de vagas, prevê atividades junto à sociedade em projetos de extensão universitária, possibilita a inserção no cenário da graduação de estudantes de pós-graduação, além da integração pesquisa e extensão. A integração de novas tecnologias e inovações pedagógicas nas atividades didáticas, como o uso da EAD, já estão incorporadas no currículo do curso. O estímulo à postura ativa na formação dos estudantes está alicerçado na inovação em sala 
de aula, no uso de metodologias ativas na sua formação e qualificação docente. As atividades de tutoria previstas no projeto pedagógico do curso visam acompanhar o desempenho dos alunos, proporcionando o respeito à singularidade no modo de aprendizagem e desenvolvimento de habilidades, além do monitoramento de dificuldades para a redução do represamento e da evasão.

\section{Objetivos do curso}

São objetivos do curso de Bacharelado em Saúde Coletiva:

- Formar profissionais para analisar crítica e propositivamente as políticas de saúde com elevado padrão de qualidade e dentro dos princípios da ética e da bioética, com senso de responsabilidade social e compromisso com a cidadania, a partir do contexto político-normativo do SUS, bem como para constituir condições para a implementação e avaliação dessas politicas;

- Formar sanitaristas, adequados às demandas do Sistema Único de Saúde, fortalecendo a descentralização da gestão, a democratização do processo decisório, a integralidade da atenção à saúde e a participação popular no âmbito dos sistemas e serviços de saúde e a intersetorialidade;

- Formar sanitarista para uma prática integrada e contínua junto às instâncias do Sistema Único de Saúde, sendo capaz de desenvolver processos de planejamento, gestão e avaliação em saúde;

- Formar sanitaristas para atuarem, direta ou indiretamente, pela promoção, vigilância e educação da saúde, individual e coletiva, garantindo atenção integral à saúde da população.

\section{Perfil do egresso}

O egresso do curso de Análise de Bacharelado em Saúde Coletiva tem competência para avaliar, organizar, dirigir e implementar atividades referentes à formulação e execução de processos institucionais no campo do planejamento, gestão e avaliação em saúde nas organizações públicas e privadas, governamentais e não-governamentais, bem como para participar das ações de promoção, vigilância e educação da saúde, tendo em vista a saúde coletiva, com capacidade de adequação às complexidades locais e regionais (no âmbito do Sistema Único de Saúde e intersetorialmente), e às mudanças que ocorrem continuamente.

O profissional formado em Saúde Coletiva atende às funções de analista no amplo setor da saúde (sanitarista), por isso o nome proposto ao curso de graduação abrange políticas (da concepção à avaliação e meta-avaliação) e sistemas (ações, serviços e modelo assistencial). O profissional, sanitarista, é pensado no âmbito da condução e regulação, onde se inclui "planejamento, gestão e avaliação em saúde" e que atua também com as ações coletivas de proteção à saúde: "educação, promoção e vigilância da saúde", além das ações sociais de participação popular e conteúdo social em saúde.

No que se refere à área de conhecimento do curso, a mesma foi definida na árvore das áreas de conhecimento da Capes, como área da Saúde coletiva, área que abrange os domínios do Planejamento, Gestão e Avaliação em Saúde e da Educação, Promoção e Vigilância da Saúde. Outros domínios são emergentes, como a ciência, tecnologia e inovação e a saúde ambiental. No Brasil, o profissional em saúde pública é designado por Sanitarista, título atualmente utilizado por todos os egressos da especialização em saúde coletiva e suas sub áreas ou campos de domínio.

Justifica-se, portanto, a oportunidade de construir e implementar a formação, no âmbito 
da graduação, de profissionais em Saúde Coletiva, com as diversas ênfases que a área da Saúde Coletiva oferece, permitindo a incorporação, pelo sistema de saúde do País, tanto no que diz respeito aos subsistemas público-estatal e privado-complementar, como privado-suplementar, de profissionais cujo investimento público seja mais conseqüente na esfera da educação superior básica (bacharelado), reservando a pós-graduação para as áreas de real especialidade ou para o desenvolvimento da pesquisa, racionalizando e otimizando a oferta de subespecialidades e formando, no âmbito do stricto sensu, para o desenvolvimento da pesquisa, desenvolvimento e inovação em saúde.

A caracterização da área da Saúde Coletiva como espaço de trabalho multiprofissional e interdisciplinar aponta para a necessidade da constituição de um núcleo de conhecimentos e práticas de atuação profissional, diferente da formação especializada e que pressupõe o desenvolvimento de um conjunto específico de competências e habilidades, demandadas pela complexidade da área de conhecimento e pela diversificação do setor de aplicação das políticas públicas da saúde. Esse núcleo de conhecimentos e práticas formaliza um recorte profissional, mas não um território de práticas privativas, apenas territórios de atuação específica e territórios como integrante da equipe de trabalhadores da saúde, podendo aperfeiçoar-se como os demais profissionais da saúde em territórios de especialidade. Didaticamente podemos classificar os territórios de atuação profissional em quatro blocos: atuação específica (foco), atuação específica (interprofissional), atuação ampliada (interprofissional) e atuação científica e tecnológica:

\section{Estrutura Curricular}

Foi proposta uma estrutura curricular assentada em Unidades de Produção Pedagógica (UPP), cognição e sensibilidades, construídas por um conjunto de domínios do conhecimento que serão desenvolvidos sob um encadeamento construtivo, configurado para serem desenvolvido ao longo de oito semestres ou quatro anos, em uma carga horária mínima de 180 horas (3.000 horas-aula +12 créditos complementares), sendo 2.370 horas, distribuídas em atividades teórico-práticas, 600 horas de Estágio Curricular, no formato Internato em Área Profissional, divididas em 300 horas de Estágio Curricular I - Planejamento, Gestão e Avaliação em Saúde e 300 horas de Estágio Curricular II - Promoção, Vigilância e Educação da Saúde. São acrescidas a essa carga horária 30 horas de Trabalho de Conclusão de Curso e 12 créditos para atividades complementares (mínimo de 180 horas). A estrutura curricular garante o contato amplo com a realidade e os temas da Saúde Coletiva do início ao fim da formação, induzindo-se um afunilamento da formação para um domínio profissional mais específico de atuação que configura a profissão ou núcleo de conhecimentos e práticas do Bacharel em Saúde Coletiva (Sanitarista).

A proposta curricular do Bacharelado em Saúde Coletiva contempla dois grandes eixos de formação, distribuídos em seis Unidades de Produção Pedagógica (Súmulas das UPPs em anexo):

Eixo 1: Planejamento, Gestão e Avaliação em Saúde;

Eixo 2: Promoção, Vigilância e Educação da Saúde.

Os eixos formativos marcam uma opção da proposta da UFRGS em produzir iniciativas que abordem, na perspectiva da saúde coletiva, o tema do planejamento, gestão e avaliação, como recorte específico na atuação interprofissional, relacionado com a promoção, vigilância e educação da saúde, como recorte ampliado na atuação interprofissional.

As súmulas das Unidades de Produção Pedagógica são deliberadamente similares, pois indicam o aprofundamento nos diferentes semestres ao longo do curso de uma mesma base de conteúdos. Os conteúdos das Unidades articulam-se e complementam-se entre si. As dinâmicas de funcionamento das Unidades não são semelhantes à estrutura disciplinar vigente na 
formação acadêmica da UFRGS. Prevê-se que as Unidades proponham um diálogo interdisciplinar que se assenta também em metodologias que privilegiam a interrogação a partir de análises de situação em territórios vivos, e no sistema de atenção à saúde. A formação profissional básica, em seu formato mais contemporâneo, prevê a integração ensino-serviço desde o primeiro dia de aula, essa é a noção do ensino embasado em problemas da realidade, do ensino embasado em projetos, e do ensino embasado em situações-problemas, diferentes modalidades que tornam as disciplinas ultrapassadas. Nesse sentido, prevê-se que a graduação se aproxime de um lado dos processos formativos da Pós-Graduação, e de outro dos processos formativos da Educação Escolar. São seis as Unidades de Produção Pedagógicas( núcleos de saberes), além de oito de Tutoria, cinco Unidades Integradoras e dois Internatos de Prática Profissional.

I - Unidade de Políticas Públicas e Sistemas de Saúde

II - Unidade de Planejamento, Gestão e Avaliação em Saúde

III - Unidade de Saúde, Sociedade e Humanidades

IV - Unidade de Análise de Situação de Saúde e Vigilância à Saúde

V - Unidade de Pesquisa em Saúde e Bioestatística

VI - Unidade de Promoção e Educação da Saúde

VII - Unidade Tópicos Integradores em Saúde Coletiva

VIII - Unidade de Tutoria

\section{Conteúdos Curriculares}

I - Unidade de Políticas Públicas e Sistemas de Saúde: atividades de ensino envolvendo domínios de conhecimento como teoria política, políticas públicas; história da saúde, institucionalização das práticas; história da organização do sistema de saúde no Brasil; reforma sanitária; comparação de sistemas de saúde; saneamento, urbanização e meio ambiente; politicas e programas de saúde; organização do sub-setor de saúde suplementar e suas estruturas de regulação; saúde suplementar.

II - Unidade de Planejamento, Gestão e Avaliação em Saúde: atividades de ensino envolvendo domínios de conhecimento como teoria das organizações; planejamento e gestão de políticas gerenciamento de serviços e sistemas de saúde; estratégias e modelos tecnoassistenciais; informática e informação em saúde em saúde; gestão do trabalho e da educação na saúde; controle, monitoramento e avaliação em saúde; auditoria e regulação em saúde; economia da saúde e avaliação econômica no setor saúde; avaliação de políticas de serviços, de programas e de ações no setor da saúde; avaliação de tecnologias em saúde; ciência, tecnologia e inovação em saúde.

III - Unidade de Saúde, Sociedade e Humanidades: atividades de ensino envolvendo domínios de conhecimento como antropologia da saúde; sociologia da saúde; gênero e diversidades humanas na formulação, condução e apreciação de ações do setor da saúde; legislação e direito em saúde; participação da população e controle social nos serviços e sistemas de saúde; desenvolvimento ambiente e saúde; geografia humana de interesse ao setor da saúde; arte, cultura e saúde; ética e bioética na atuação em saúde e na produção de conhecimentos.

IV - Unidade de Análise de Situação de Saúde e Vigilância à Saúde: atividades de ensino envolvendo domínios de conhecimento como epidemiologia; medidas e indicadores em saúde coletiva; vigilância epidemiológica, ambiental e sanitária; vigilância nutricional e segurança alimentar; saúde do trabalhador; práticas de biossegurança; análise de risco; análise de situ- 
ação de saúde; demografia; geoprocessamento; carga de doença e determinantes em saúde.

V - Unidade de Pesquisa em Saúde e Bioestatística: atividades de ensino envolvendo domínios de conhecimento como tecnologias de busca e uso da informação científica e bibliográfica em saúde; pesquisa e produção de conhecimento em saúde; bioestatística; métodos de pesquisa qualitativa em saúde; métodos gráficos; ética em pesquisa; divulgação científica e tecnológica em saúde; leitura de artigos científicos e busca de evidências técnico-científicas.

VI - Unidade de Promoção e Educação da Saúde: atividades de ensino envolvendo domínios de conhecimento como educação e comunicação; educação permanente em saúde e educação de profissionais de saúde; educação popular em saúde; práticas multiprofissionais e trabalho em equipe; programas/políticas de saúde para grupos populacionais, culturas urbano e rural; ciclos de vida e necessidades em promoção da saúde; redes sociais e proteção de saúde, movimentos sociais por saúde, espaço e ambientes em saúde; integralidade em saúde; qualidade de vida; saúde mental coletiva; escuta pedagógica das práticas de saúde; pedagogias dos processos coletivos.

VII - Unidade Tópicos Integradores em Saúde Coletiva: esta Unidade, implementada na modalidade de EAD, busca desenvolver, em cada semestre, temas transversais às diferentes UPPs, visando integrar os diferentes conteúdos aos conhecimentos e práticas da Saúde Coletiva que constituem a base das competências e habilidades a serem desenvolvidas na seqüência do curso.

VIII - Unidade de Tutoria: as atividades de tutoria, propostas no Currículo do Curso de Bacharelado em Saúde Coletiva, compõem a estratégia principal de construção de habilidades e competências com densa reflexão sobre a prática e a produção de conhecimentos associados às mesmas, assim como à avaliação de habilidades desenvolvidas.

\section{Metodologia}

A partir de referenciais teórico-conceituais e politico-filosóficos presentes no ensino da saúde, é apresentado o projeto pedagógico para o curso de Bacharelado em Saúde Coletiva. O projeto respeita as Normas Básicas da Graduação na Universidade Federal do Rio Grande do Sul, propondo-se à construção de um Currículo Integrado, organizado por Unidades de Produção Pedagógica (UPP), articuladas para o desenvolvimento e produção de um conhecimento interdisciplinar e de uma implicação ética com os resultados em saúde.

A estrutura curricular é assentada em UPPs, construídas por um conjunto de domínios do conhecimento que são desenvolvidos sob um encadeamento construtivo. Nesta perspectiva, tanto o ensino quanto a aprendizagem devem traduzir uma vivência de integração das atividades como produção formativa ao longo da UPP, mostrando que professor e estudante estão presentes nas diferentes etapas do seu desenvolvimento. Assim, as Unidades de Produção Pedagógica (UPP) são articuladas de forma longitudinal e "conseqüencial" na proposta de currículo integrado para o desenvolvimento e produção de um conhecimento interdisciplinar.

Essa proposta de organização curricular se estrutura a partir do pressuposto da educação permanente em saúde, nos termos em que se tornou politica pública no Sistema Único de Saúde (SUS), para ensejar a integração entre trabalho em saúde, formação profissional e cidadania e pretende ser agregadora de áreas e unidades acadêmicas dentro da universidade. A integração interdepartamental se focará entre departamentos gestores das cargas horárias dos docentes que atuarão no curso, entre os departamentos da Escola de Enfermagem e entre os departamentos que compartilham seus eixos complementares, como Economia e Educação. 
(1)

Cada UPP corresponde a um agregado dos conteúdos e práticas (núcleo de saberes) de domínio do profissional da saúde coletiva no exercício das funções profissionais em saúde pública, assim cada UPP corresponde, também, à gestão docente colegiada desse agregado de conteúdos e práticas. Isto quer dizer que a gestão do curso se assenta principalmente sobre a sua produção pedagógica junto aos alunos e não sobre a gestão administrativa da educação (gestão das cargas horárias, número de créditos, distribuição dos encargos etc.).

$\mathrm{Na}$ medida em que cada UPP é um colegiado de docentes, agregados pelo compartilhamento solidário e co-responsável do ensino de um núcleo de saberes, deverá gerir o desenvolvimento das aprendizagens desse núcleo de saberes junto aos alunos, mas também junto ao desenvolvimento docente permanente e junto à condução da educação no formato de um curso de graduação.

\section{Estágio Curricular Supervisionado}

O Estágio Curricular se constitui por atividades prático-aplicativas de inserção do discente em espaços da atuação profissional sob supervisão direta de profissionais dos diferentes campos ocupacionais e orientação pelos professores do curso, somando 600 horas, sem tradução por créditos, mas distribuídas igualmente entre os dois grandes eixos de formação (Planejamento, Gestão e Avaliação em Saúde e Promoção, Vigilância e Educação da Saúde).

Os Estágios Curriculares são atividades de ensino de caráter prático-aplicativo, são obrigatórios à integralização do curso e compreendem um conjunto de atividades implicadas com a atuação profissional na análise de políticas e sistemas de saúde, envolvendo a interação com agentes sociais; a compreensão da organização e do planejamento da saúde; o planejamento, execução e avaliação de atividades, bem como a educação e comunicação em sistemas informacionais e redes interativas.

Os Estágios Curriculares de Saúde Coletiva correspondem aos dois eixos do curso, Planejamento, Gestão e Avaliação em Saúde e Promoção, Vigilância e Educação da Saúde. Como atividades de ensino, constam de uma dimensão teórica, configurada em um Plano de Ensino, e de uma dimensão prática, configurada em um Plano de Trabalho individualizado para cada estagiário, contemplando as especificidades de cada espaço educativo e potencializando as interações universidade-sociedade por meio do exercício prático-aplicativo da prática profissional em formação. Na sua dimensão teórica, os estágios curriculares serão desenvolvidos em turmas sob a responsabilidade de docente da universidade, o qual apresentará Plano de Ensino compatível com o eixo. Na sua dimensão prática, os Estágios Curriculares serão desenvolvidos em conformidade com o Plano de Ensino, mas contarão com um Plano de Trabalho individualizado para cada aluno, registrado e sistematizado como plano de estágio, o qual será compartilhado com profissional supervisor do respectivo espaço educativo.

Os espaços educativos devem contemplar a existência de vínculo institucional com a Universidade, seja por meio de convênio, contrato, projeto, programa ou outras modalidades de cooperação interinstitucional, dando-se preferência para a rede pública de saúde ou para espaços educativos de especial interesse ao Sistema Único de Saúde. Os locais de Estágio de Docência devem atender aos requisitos de proporcionar vivência efetiva de situações concretas de prática profissional dentro da área de conhecimento da Saúde Coletiva; possibilitar o aprofundamento dos conhecimentos teórico-práticos; contar com infra-estrutura compativel com as aprendizagens do estágio; permitir que o estagiário desenvolva as atividades propostas em seu plano de estágio; possuir em seu quadro funcional profissional com disponibilidade de acompanhar práticas de saúde pública por meio de supervisão.

As diretrizes do Estágio Curricular estão estruturadas pelo Regulamento do Estágio Curricu- 
lar do Curso e pela Resolução nº 03/2012 da ComGrad/Col.

\section{Atividades complementares}

A Comissão de Graduação do Curso de Análise de Políticas e Sistemas de Saúde - Bacharelado em Saúde Coletiva, por meio da Resolução $\mathrm{n}^{\circ}$ 10/2009, regulamenta as Atividades Complementares para o curso. A Resolução foi estabelecida com base na Resolução n ${ }^{\circ}$ 4/2006 do Conselho de Ensino, Pesquisa e Extensão da Ufrgs. As atividades poderão ser desenvolvidas em qualquer momento do curso, e os alunos devem cursar quatro tipos de atividades complementares, cumprindo um total de 12 créditos nos termos da referida Resolução.

\section{Trabalho de Conclusão de Curso - TCC}

\section{TRABALHO DE CONCLUSÃO DE CURSO - REGULAMENTO INTERNO 2011}

O Trabalho de Conclusão de Curso - TCC previsto no projeto pedagógico e constante na estrutura curricular, é desenvolvido em 2 etapas, no sétimo e oitavo semestres do Curso de Graduação Análise de Politicas e Sistemas de Saúde, e integraliza para cada etapa 15 horas (1 crédito) teórico e preparatório, totalizando 30 horas ( 2 créditos). O professor responsável pela atividade elabora Plano de Ensino especifico para cada uma das etapas.

\section{DEFINIÇÃO}

O Trabalho de Conclusão de Curso - TCC, do Curso de Graduação em Análise de Politicas e Sistemas de Saúde - Bacharelado em Saúde Coletiva, é um trabalho acadêmico utilizado como exercício das habilidades previstas ao profissional de saúde coletiva, compondo a avaliação final dos graduandos. Para a realização do TCC os graduandos terão de efetivar matrícula em duas atividades de ensino obrigatórias, designadas como TCC I e TCC II, correspondendo TCC I a etapa de projeto e TCC II a etapa de execução do projeto e redação do relatório final. O escopo e o formato do TCC é o de um trabalho com pesquisa e/ou documentação, sob orientação, podendo assumir característica científica, tecnológica, estético-expressiva ou bibliográfica, envolvendo avaliação pelo orientador e um examinador-parecerista. O TCC em saúde coletiva poderá ser desenvolvido nas seguintes modalidades:

a) Informe Científico-Tecnológico;

b) Protótipo;

c) Performance;

d) Programa de Ação;

e) Revisão Bibliográfica ou Estado da Arte na Literatura;

f) Artigo Científico (segue a proposta da revista de submissão)

g) Monografia

\section{SÚMULA TCC I}

Trabalho de Conclusão de Curso I - TCC I é a atividade, sob orientação, desenvolvida para a produção de projeto versando sobre domínios específicos da atuação profissional em saúde coletiva, em um dos seguintes eixos: Planejamento, Gestão e Avaliação em Saúde ou promoção, Educação e Vigilância da Saúde. Para aprovação em TCC I será necessário um parecer circunstanciado favorável do orientador. 
SÚMULA TCC II

Trabalho de Conclusão de Curso II é atividade, sob orientação, desenvolvida para a produção de relatório com formato técnico-científico ou monográfico, individual, que represente o desdobramento do projeto aprovado. Para a aprovação em TCC II serão necessários dois pareceres circunstanciados favoráveis, um do orientador e um de avaliador convidado.

\section{Apoio ao Discente}

O aluno do Curso Análise de Políticas e Sistemas de Saúde - Bacharelado em Saúde Coletiva, no que tange ao atendimento ao discente na Unidade, tem na secretaria da Comissão de Graduação o acesso às informações referentes à sua vida acadêmica, resolvendo diretamente questões ou dando o encaminhamento para resolução das mesmas. Na secretaria, são disponibilizadas informações e documentos referentes à sua vida acadêmica, como as referentes às matrículas, análise de aproveitamento, liberações ou equivalências de disciplinas, encaminhamento dos estágios não-obrigatórios, das atividades complementares, mobilidade acadêmica no âmbito nacional e internacional, análise para diplomação e jubilamento, entre outros. Contam também com representação local na EENF da Relinter - Secretaria de Relações Internacionais para intercâmbios e Mobilidade Acadêmica. A secretaria atende de segunda à sexta-feira, das 16 às 22 horas, com o atendimento podendo ser presencial ou por e-mail, conforme a necessidade do aluno. Ainda é possivel obter informações e documentos por meio do sítio da COMGRAD (www.ufrgs.br/saudecoletiva), evitando, muitas vezes, o deslocamento do aluno para uma consulta presencial.

Em relação às orientações pedagógicas relativas ao curso, a coordenação da COMGRAD tem horários pré-estabelecidos de atendimento ao aluno, orientando, entre outros, nas escolhas de matrícula e nas prioridades de atividades para complementação curricular. Além disso, o aluno conta com o professor orientador de turma, que deverá acompanhar, de forma tutorial e de orientação, uma turma de estudantes, a partir de seu ingresso até a conclusão, figurando como um interlocutor qualificado no processo de formação. Trata-se de um espaço da tutoria com reunião semanal de uma hora do professor responsável com a turma.

No que se refere ao atendimento do aluno na Universidade, existe uma infraestrutura consolidada com instâncias próprias para o planejamento, execução, avaliação e aperfeiçoamento de diferentes ações, podendo ser relativas aos espaços de desenvolvimento de atividades de ensino, ao apoio-pedagógico, aos estágios, ao sustento individual (benefícios de assistência como alimentação, moradia, auxílio-transporte; bolsas) e outros. Entre os órgãos da Universidade responsáveis por estas questões se encontram:

- Pró-Reitoria de Assuntos Estudantis (PRAE): é a instância institucional responsável pela execução da política de assistência ao estudante e possui como objetivo tratar das questões relativas à assistência estudantil, visando disponibilizar os meios que garantam as condições de permanência e diplomação dos alunos, tendo como um dos objetivos superar os elevados custos da evasão escolar-acadêmica e da repetência. Atua ainda em ações especificas de atendimento ao discente como: acompanhamento aos moradores das Casas de Estudantes Universitários (SAM), análise de desempenho acadêmico e, atendimento a portadores de necessidades especiais.

- Departamento de Controle e Registro Discente (DECORDI): responsável pelas atividades de planejamento, coordenação e gerência de dados da vida acadêmica, desde a primeira matrícula até a colação de grau. Controlar e registrar as informações relativas aos cursos de graduação, como currículos, horários, vagas das disciplinas e expede documentos como histórico escolar, atestados, entre outros. 
- Departamento de Atenção à Saúde (DAS): que atende aos alunos nas questões voltadas à sua saúde.

- Núcleo de Atendimento ao Estudante (NAE), composto por uma equipe com psicólogos, assistente social e técnica em assuntos educacionais (pedagoga), para atender o aluno no que diz respeito ao seu desenvolvimento e planejamento de carreira e sua adaptação à universidade.

- Ouvidoria da UFRGS: vinculada ao Gabinete do Reitor, tem como missão ouvir o cidadão, registrar, encaminhar, acompanhar as demandas, mediar conflitos e aperfeiçoar o processo de trabalho dentro da Universidade.

- Diretório Central de Estudantes (DCE) e Diretórios Acadêmicos (DAs).

\section{Ações Decorrentes dos Processos de Avaliação do Curso}

O Curso Análise de Políticas e Sistemas de Saúde - Bacharelado em Saúde Coletiva realiza permanentemente avaliação interna e externa. Fazem parte deste processo o Núcleo de Avaliação da Unidade (NAU), a avaliação docente realizada pelos discentes e o ENADE.

NAU: Núcleo ligado a outros setores de avaliação institucional. Compete ao NAU construir uma cultura de avaliação na Unidade que permita analisar a distância entre onde se está e onde se quer chegar. Constituem o plano de ação: ETAPA 1: Mapeamento dos setores a partir de relatório fornecido pelas chefias/coordenações abordando recursos físicos, humanos e funções desenvolvidas. ETAPA 2: Percepção das equipes de trabalho sobre o seu setor a partir do roteiro inicial e das 10 dimensões de avaliação do MEC. ETAPA 3: Percepção do público atendido sobre os diferentes setores. ETAPA 4: Percepção de cada setor em relação aos demais com os quais se relaciona.

Avaliação dos docentes pelos discentes: Os alunos regularmente matriculados no Curso Análise de Políticas e Sistemas de Saúde - Bacharelado em Saúde Coletiva realizam uma avaliação das Unidades de Produção Pedagógica (UPPs), infra-estrutura e docentes semestralmente. O objetivo desse instrumento é saber a opinião dos alunos sobre o desenvolvimento das disciplinas, com vistas ao aperfeiçoamento constante do ensino, do currículo e da infra-estrutura do seu curso de graduação. Eles também realizam uma autoavaliação e podem também realizar críticas, sugestões e comentários complementares.

\section{Atividades de Tutoria}

As atividades de tutoria propostas no Currículo do Curso de Bacharelado em Saúde Coletiva compõem a estratégia principal de construção de habilidades e competências com densa reflexão sobre a prática e a produção de conhecimentos associados às mesmas, assim como à avaliação de habilidades desenvolvidas. Da forma como foi prevista no projeto político-pedagógico, essa modalidade de atividades constituiu dificuldades operacionais que comprometem a potência prevista inicialmente, em particular sobrecarga em uma única UPP, o impedimento à participação de estudantes não matriculados nessa UPP específica e problemas para o registro da responsabilidade pedagógica dos docentes na nucleação de grupos nos quais é viável e produtiva a realização dessa modalidade. Para superar o problema constatado e potencializar a estratégia da tutoria, a Comissão de Graduação do Curso de Bacharelado em Saúde Coletiva optou pela criação desta UPP, de forma a garantir singularidade no desenvolvimento e na avaliação do estudante no processo do ensino-aprendizagem em pequenos grupos. 
Tecnologias de Informação e Comunicação (TICs) no Processo de Ensino-Aprendizagem

- Software Breeze: O sistema Breeze Meeting da Macromedia foi contratado pela UFRGS e permite que os professores agendem sessões de atividade envolvendo não apenas o uso de videoconferência com múltiplos participantes, como também o compartilhamento de aplicações, apresentação de slides, uso concorrente de quadro branco, quadro de notas, ferramenta de chat e gravação de sessões para posterior re-exibição.

- SPSS: Software de análise estatística para uso em pesquisas, disponibilizado aos professores e alunos da UFRGS.

- Epi-Info: Software de domínio público criado para profissionais e pesquisadores da área da saúde pública (Informação Epidemiológica). Constitui-se em um modo fácil para formatação e construção de base de dados, inserção de dados e análise com métodos estatísticos epidemiológicos, mapas e gráficos. Possibilita a elaboração de mapas geográficos com inserção de dados do próprio software.

- N Vivo: Software de análise qualitativa para uso em pesquisas, disponibilizado aos professores e alunos da UFRGS.

- End Notes:Software de referenciação bibliográfica para uso em pesquisas e redação de informes técnico-científicos, disponibilizado aos professores e alunos da UFRGS.

- Arc View e Mapinfo: Softwares para geoprocessamento

- Plataforma Moodle: Software para gestão da aprendizagem e de trabalho colaborativo, permitindo a realização de cursos à distância ou suporte para atividades das disciplinas presenciais da UFRGS. Conta com as principais funcionalidades de um ambiente virtual de aprendizagem. Possui ferramentas de comunicação, de avaliação, de disponibilização de conteúdos e de administração e organização. Elas são acessíveis pelo professor de forma separada em dois tipos de entradas na página do curso. De um lado adiciona-se o Material através dos recursos, e do outro as atividades.

- Excel: Software de planilha eletrônica ou de cálculos.

\section{Mecanismos de Interação entre Docentes, Tutores e Estudantes}

A Unidade Tópicos Integradores em Saúde Coletiva, implementada na modalidade de EAD, busca desenvolver, em cada semestre, temas transversais às diferentes UPPs, visando integrar os diferentes conteúdos, tutores, discentes, docentes e os conhecimentos e práticas da Saúde Coletiva que constituem a base das competências e habilidades a serem desenvolvidas na sequência do curso. A integração entre eixos disciplinares em campos de atuação é argumento central na construção das UPPs, conforme o projeto político-pedagógico do curso. A singularidade desta UPP é a produção de atravessamentos e transversalidades entre as UPPs ofertadas em cada semestre com dimensões da prática profissional nos sistemas e serviços de saúde. A carga horária da modalidade EAD, que já compõe as estratégias de ensino no projeto político pedagógico do Curso, será totalmente utilizada nesta UPP. A inovação curricular se mostra necessária neste momento de implementação do curso, uma vez que apenas com a previsão de alcançá-la com atividades a serem realizadas em uma das UPPs nas quais estava vinculada não se mostrou com suficiente potência. Assim, a Comissão de Graduação do Curso de Bacharelado em Saúde Coletiva optou, após a análise em maior profundidade, na proposição desta nova UPP de forma a garantir a transversalidade prevista. 


\section{Procedimentos de Avaliação dos Processos de Ensino-Aprendizagem}

A avaliação é formativa e somativa, assumindo um papel preponderante no acompanhamento dos alunos e na melhoria do processo educativo. A partir da análise de situações reais ou simuladas, o desenvolvimento da atividade educacional permite que todos expressem seus saberes prévios, buscando identificar percursos onde os problemas em situação se tornem construção do conhecimento. As atividades de ensino priorizam, sempre que possivel, o trabalho realizado em grupos.

As atividades realizadas visam em um primeiro momento a observação e a avaliação do desempenho de cada estudante frente a uma situação em um ambiente que reproduza um cenário da vida real e, em um segundo momento, pelo apoio direcionado à exploração e fundamentação de novas capacidades identificadas no acompanhamento permanente, finalizando com a construção de consolidados provisórios de saberes aplicados.

A escolha dos cenários e a movimentação dos estudantes por esses espaços são discutidas e acordadas entre os serviços, entidades ou instituições e a Universidade, considerando-se a estrutura e organização da saúde no município e locorregião metropolitana.

A avaliação é uma atividade permanente e constituinte do processo de ensino-aprendizagem, permitindo o acompanhamento desse processo e tornando visíveis os avanços e as dificuldades para promover ações de modo a melhorar os processos, produtos e resultados.

A avaliação é realizada por todos os envolvidos na construção do currículo, deve ser livre de medos e possibilitar que os atores do processo ensino-aprendizagem expressem suas percepções, objetivando e exemplificando os aspectos considerados adequados e os que precisam ser melhorados, reformulados ou mesmo substituídos. O respeito e a responsabilidade nesse processo são fundamentais para a garantia de um clima de cooperação ética. A Comissão de Graduação do Bacharelado em Saúde Coletiva faz o acompanhamento do desenvolvimento do curso, particularizando cada turma, como forma de apoiar as transformações contínuas e reorientar processos para a melhor formação dos alunos nas competências e habilidades estipuladas ou atualizadas ao perfil do egresso.

O desempenho do Professor é avaliado pelos estudantes, utilizando o instrumento de avaliação disponibilizado no site da universidade ao final de cada semestre. Os professores incentivam seus alunos ao preenchimento do instrumento, assim como a COMGRAD e o Departamento de Controle e Registro Discente.

A avaliação dos professores é feita pelos estudantes, segundo roteiro elaborado pela Secretaria de Avaliação Institucional da UFRGS. A avaliação de disciplinas e de professores pelos alunos é realizada de maneira rotineira ao final de cada semestre. Este processo é pensado pela Universidade no sentido de valorizar a opinião dos alunos na análise da qualidade do ensino oferecido. Um instrumento padronizado é utilizado para a avaliação pelos alunos sobre o desempenho dos docentes, sobre o desenvolvimento da UPP e sobre as condições de infra-estrutura ao ensino-aprendizagem. Ao final há um espaço de auto-avaliação referido às aprendizagens que confere indicador ao processo de ensino.

\section{Número de vagas}

O curso Análise de Políticas e Sistemas de Saúde - Bacharelado em Saúde Coletiva da UFRGS oferece à comunidade 60 vagas anuais com ingresso de 30 alunos no primeiro, e 30 alunos no segundo semestre do ano letivo. O ingresso dos estudantes ao Curso Análise de Políticas e Sistems de Saúde - Bacharelado em Saúde Coletiva da UFRGS se dá fundamentalmente por intermédio do Concurso Vestibular, realizados por candidatos que tenham concluído o ensino 
médio ou equivalente, nos termos da lei e das normas regulamentares da Universidade, realizado anualmente nesta Instituição. Outra forma de acesso ao curso é o Ingresso Extravestibular (conforme RES. $n^{\circ} 11 / 2005$ e no 15/2009 do CEPE/UFRGS, que aprova normas complementares ao Ingresso Extravestibular) que pode acontecer por transferência interna; ingresso de diplomado; transferência voluntária; permanência em curso; aluno convênio; alunos especiais.

O curso também atende à Decisão no 134/2007 do Conselho Universitário que instituiu o Programa de Ações Afirmativas, através de Ingresso por Reserva de Vagas para acesso a todos os cursos de graduação e cursos técnicos da Universidade Federal do Rio Grande do Sul-UFRGS, de candidatos egressos do Sistema Público de Ensino Fundamental e Médio, candidatos autodeclarados negros egressos do Sistema Público de Ensino Fundamental e Médio e candidatos indigenas, conforme os artigos $5^{\circ}, 6^{\circ}$ e 11 :

Art. $5^{\circ}$ - Do total das vagas oferecidas em cada curso de graduação da UFRGS serão garantidas, no mínimo, 30\% (trinta por cento) para candidatos egressos do Sistema Público de Ensino Fundamental e Médio.

Art. $6^{\circ}$ - Do total das vagas oferecidas aos candidatos egressos do Sistema Público de Ensino Fundamental e Médio, conforme estabelecido no caput do Art. $5^{\circ}$, no mínimo a metade será garantida aos estudantes autodeclarados negros, sem prejuízo ao disposto no $3^{\circ}$ do Art. 10. Art. $11-\S 2^{\circ}$ - As vagas para indigenas serão criadas, anualmente, especificamente para este fim. Aquelas que não forem ocupadas serão extintas.

\section{Integração com o Sistema Local, Regional e Nacional de Saúde}

A fim de viabilizar a realização de trabalhos de campo, vivências em educação popular e em locorregiões interioranas e a atuação em instâncias participativas do SUS, são utilizados dias não-letivos e poderão ser previstas, no Calendário Universitário, atividades que necessitem exceder o período letivo regular.

O desenvolvimento das atividades de ensino é sustentado nas parcerias desenvolvidas pela Escola de Enfermagem e pela Universidade. A Escola de Enfermagem está inserida na política de fortalecimento da interação da Universidade com a sociedade, nos âmbitos local, regional, nacional e internacional, e visa:

- interação com o setor público, com o setor privado, com o terceiro setor e com os movimentos sociais;

- integração com Instituições de Ensino Superior públicas e comunitárias do Estado, da Região Sul e do país;

- estímulo às atividades de pesquisa, extensão e em tecnologias sociais;

- estabelecimento de políticas de cooperação intelectual.

Dessa forma, a Escola de Enfermagem estabelece as parcerias adequadas ao longo do desenvolvimento das Unidades de Produção Pedagógica, formadas ao longo da estruturação das atividades teóricas, teórico-práticas e prático-aplicativas do curso. As parcerias envolvem espaços educativos no Sistema Único de Saúde (Estatal e Complementar e subsistema Suplementar), em articulações intersetoriais podendo incluir a parceria com espaços no movimento social e popular e, em situações de excepcional interesse acadêmico, espaços pontuais, inovadores ou por aposta construtiva. As parcerias contemplam vinculação institucional com a UFRGS por meio de convênios, contratos, projetos, programas ou outras modalidades de cooperação interinstitucional.

Atualmente, a Escola de Enfermagem contempla parcerias com a rede de saúde local e region- 
al, citando-se, entre outros:

- Hospital de Clínicas de Porto Alegre (Hospital Universitário);

- Secretaria de Estado da Saúde do Rio Grande do Sul;

- Prefeitura Municipal de Porto Alegre/RS - Saúde;

- Prefeitura Municipal de Cachoeirinha/RS - Saúde;

- Prefeitura Municipal de Canoas/RS - Saúde;

- Prefeitura Municipal de Gravataí/RS - Saúde;

- Hospital Porto Alegre;

- Irmandade Santa Casa de Misericórdia de Porto Alegre;

- Grupo Hospitalar Conceição;

- Instituto do Coração/Fundação Universitária de Cardiologia;

- Unimed;

- Adote - Assistência Domiciliar Terapêutica;

- Fundação de Articulação e Desenvolvimento de Políticas Públicas para Pessoas Portadoras de Deficiências e de Altas Habilidades no Rio Grande do Sul;

- Fundação Estadual de Pesquisa e Produção em Saúde.

As parcerias são ampliadas para além da Escola de Enfermagem se considerarmos o âmbito da UFRGS como um todo. A faculdade de Educação, parceira orgânica do Bacharelado em Saúde Coletiva mantém convênios de estágio e cooperação com:

- Prefeitura Municipal de Novo Hamburgo/RS - Saúde;

- Prefeitura Municipal de Viamão/RS - Saúde;

- Grupo Hospitalar Conceição;

- Fundação Oswaldo Cruz;

- Assessoria de saúde Indígena da Fundação Nacional de Saúde no Rio Grande do Sul - subsistema de saúde indigena do SUS. As novas parcerias envolvem espaços educativos no

Sistema Único de Saúde (estatal, complementar e suplementar). Particularmente estão incluídas as parcerias com o espaço do movimento social e popular, controle social, terceiro setor e cenários que se impõem pela importância estratégica, como por exemplo, aqueles relacionados à Saúde Ambiental, desenvolvimento sustentável e biotecnologias, entre outros. $\mathrm{Na}$ organização curricular e estruturação da proposta pedagógica do curso, a articulação ensino-serviço-gestão-participação se dá por meio de tecnologias que promovam interação e espaços de encontro para atuação em equipe, de forma multiprofissional e interdisciplinar, voltada às necessidades locorregionais.

\section{Atuação do Núcleo Docente Estruturante (NDE)}

Conforme Resolução $\mathrm{n}^{\circ} 22$ de 04 de julho de 2012 da UFRGS, o NDE, instituído em cada curso de Graduação da Universidade pelo seu Conselho de Unidade, tem caráter consultivo, para acompanhamento do curso, visando à contínua promoção de sua qualidade.

A Portaria $n^{\circ} 46$ de 26 de julho de 2012, assinada pela Diretora em Exercício da Escola de Enfermagem, designa os professores Marta Julia Marques Lopes (Coordenadora), Alcides Silva de Miranda, Alcindo Antonio Ferla, Stela Nazareth Meneghel, Ricardo Burg Ceccim 
e Cristianne Maria Famer Rocha para comporem o Núcleo Docente Estruturante do Curso Análise de Políticas e Sistemas de Saúde. Todos os membros do NDE do Curso apresentam titulação acadêmica em Programas Stricto Sensu e possuem regime de trabalho de Dedicação Exclusiva. Com a constituição oficial do NDE, são realizadas reuniões periódicas, de cunho administrativo e pedagógico voltadas à organização curricular e das disciplinas, com todos os professores lotados no Departamento de Assistência e Orientação Profissional e que trabalham diretamente com o curso Análise de Políticas e Sistemas de Saúde - Bacharelado em Saúde Coletiva, para uma constante análise do desenvolvimento do curso, além de reuniões com todos os professores incluindo os demais departamentos envolvidos com o curso.

\section{Atuação da Coordenadora}

A Coordenadora da COMGRAD assegura o desenvolvimento das atribuições Estatutárias e regimentais da mesma, lidera a Comissão e estabelece a articulação institucional intra e extra unidade acadêmica nas questões relativas ao ensino. Dispõe de carga horária semanal (20 horas) para o exercício da função, inclusive atendimentos aos estudantes. Reúne-se mensalmente com a Comissão para garantir o cumprimento da gestão colegiada. Participa do fórum de coordenadores em consonância com a proposta institucional da Ufrgs através de convocação periódica.

Conforme o Estatuto da UFRGS são atribuições da COMGRAD:

Art. 46. Os Cursos de Graduação serão coordenados por Comissões de Graduação, constituídas por representantes dos Departamentos que ministrem disciplinas do Curso, com mandato de 2 (dois) anos, de acordo com o Regimento Geral da Universidade, e pela representação discente na proporção de 1 (um) aluno para cada 5 (cinco) docentes, escolhidos de acordo com o Regimento Interno da Unidade.

Parágrafo único. Será assegurada maioria aos Departamentos de Unidade a qual o Curso se vincule, exceto nos casos de Cursos em Parceria, que obedecerão a regra própria definida no Regimento Geral.

Art. 47. A Comissão de Graduação terá um Coordenador com mandato de 2 (dois) anos, eleito na forma do Regimento Geral da Universidade, com funções executivas.

Art. 48. Compete à Comissão de Graduação:

I - propor ao Conselho da Unidade, ouvidos os Departamentos envolvidos, a organização curricular e atividades correlatas dos cursos correspondentes;

II - avaliar periódica e sistematicamente o currículo vigente, com vistas a eventuais reformulações e inovações, deliberando sobre emendas curriculares observadas as diretrizes curriculares emanadas pelo Poder Público;

III - propor ações ao Conselho da Unidade, relacionadas ao ensino de graduação;

IV - avaliar os planos de ensino elaborados pelos Departamentos;

$\mathrm{V}$ - orientar academicamente os alunos e proceder a sua adaptação curricular;

VI - deliberar sobre processo de ingresso, observando a política de ocupação de vagas estabelecida pela Universidade;

VII - aprovar e encaminhar periodicamente à Direção da Unidade a relação dos alunos aptos a colar grau. 


\section{Experiência Profissional, de Magistério Superior e de Gestão Acadêmica da} Coordenadora

A Coordenadora é Professora Titular em Saúde Coletiva desde 1997, tendo exercido funções acadêmico-administrativas nas comissões de Pesquisa e Pós-Graduação da EENF por 2 mandatos. Atualmente, está em segundo mandato de Coordenação de Comgrad do Curso Análise de Politicas e Sistemas de Saúde.

Exerceu também representação no Comitê da Área de Enfermagem na CAPES. Participa das instâncias gestoras da Unidade como Departamento e Conselho de Unidade. Outra representação foi no Comitê de Ética em Pesquisa da UFRGS. Coordenou e coordena atualmente o Grupo de Estudos em Saúde Coletiva com Diretório inscrito no CNPQ.

\section{Regime de trabalho da Coordenadora do curso}

O regime de trabalho da Coordenadora do curso, Prof ${ }^{a}$. Dr ${ }^{a}$. Marta Julia Marques Lopes, e do coordenador substituto, Prof. Dr. Ricardo Burg Ceccim, é de Dedicação Exclusiva.

\section{Carga Horária da Coordenadora do Curso}

A Coordenadora da COMGRAD dispõe de carga horária semanal de 20 horas para o exercício da função, inclusive atendimentos aos estudantes.

\section{Titulação do corpo docente}

O curso Análise de Políticas e Sistemas de Saúde - Bacharelado em Saúde Coletiva usufrui de estrutura disponível no campi da Saúde e está localizado no prédio da Escola de Enfermagem. Além disso, o curso tem a colaboração de docentes vinculados a diversas unidades acadêmicas da universidade, como a Faculdade de Educação e a Faculdade de Engenharia.

Atualmente, o corpo docente é composto por nove professores adjuntos com titulação mínima de Doutorado, sendo que destes dois apresentam titulação de Pós-Doutorado. Além do corpo docente permanente, no semestre de 2012/02 o curso conta com a participação de sete professores temporários.

\section{Titulação do Corpo Docente do Curso - Percentual de Doutores}

O corpo docente do Curso Análise de Politicas e Sistemas de Saúde - Bacharelado em Saúde Coletiva possui $100 \%$ de Doutores em seu quadro permanente.

\section{Regime de trabalho do corpo docente}

Os nove docentes permanentes que atuam no curso Análise de Políticas e Sistemas de Saúde - bacharelado em Saúde Coletiva são vinculados à Universidade Federal do Rio Grande do Sul pelo Regime Jurídico Único - 40 horas e Dedicação Exclusiva (DE). Além desses, atuavam em 2012/02, sete professores temporário com regime de 20 horas.

\section{Experiência Profissional do Corpo Docente}

Tanto os professores do quadro permanente, quanto os professores temporários possuem tempo médio de experiência profissional de 10 anos. Os professores do curso acumulam experiência em áreas, tais como: atenção primária, gestão, promoção e vigilância em saúde, com grande ênfase na área da Saúde Coletiva, na Coordenação de Programas de Pós-Graduação, Coordenação de Curso de Graduação, orientação de alunos da graduação, especialização, me- 
strado e doutorado, bem como projetos de pesquisa e extensão realizadas na área da Saúde Coletiva, o que enriquece a atuação no curso, junto aos discentes e atividades desenvolvidas.

\section{Tempo de experiência de magistério superior ou experiência do corpo docente}

Dentre os professores do quadro permanente que atuam no curso, três possuem mais de 20 anos de experiência docente, quatro professores possuem de 10 a 15 anos de experiência docente e um possui quatro anos. Além dos docentes permanentes, no semestre letivo de 2013/1 o curso contará com a participação de três professores temporários, um com experiência docente de mais de 20 anos e os outros dois com experiência de 11 anos.

\section{Funcionamento do Colegiado do Curso ou Equivalente}

O curso Análise de Políticas e Sistemas de Saúde - Bacharelado em Saúde Coletiva possui na administração acadêmica a Comissão de Graduação (COMGRAD). A Comissão de Graduação do Curso tem como membros:

Prof ${ }^{a}{ }^{a}$. Marta Julia Lopes

Prof $^{a}$ Dr $^{\mathrm{a}}$. Cristianne Maria Famer Rocha

Prof Ms. Darci Barnech Campani

Prof $^{\text {a }}$ Dr $^{\mathrm{a}}$. Marilise Mesquita

Prof Dr. Ricardo Burg Ceccim

Mariana Kliemann Marchioro (Representante discente - Saúde Coletiva)

As funções de Coordenador e Coordenador Substituto estão previstas no Estatuto da Universidade, nos artigos 46 a 48, enquanto que a composição e o funcionamento da COMGRAD/ SCOL estão previstas regimentalmente no Regimento Geral da Universidade (ambos disponiveis em http:/ /www.ufrgs.br/consun/).

Estão de acordo com as politicas internas da UFRGS, são amplamente acessiveis e asseguram a participação equânime dos diversos segmentos que compõem a comunidade acadêmica.

Seguem os artigos do Estatuto:

Seção IV - Das Comissões de Graduação

Art. 46 - Os Cursos de Graduação serão coordenados por Comissões de Graduação, constituídas por representantes dos Departamentos que ministrem disciplinas do Curso, com mandato de 2 (dois) anos, de acordo com o Regimento Geral da Universidade, e pela representação discente na proporção de 1 (um) aluno para cada 5 (cinco) docentes, escolhidos de acordo com o Regimento Interno da Unidade.

Parágrafo único - Será assegurada maioria aos Departamentos de Unidade a qual o Curso se vincule, exceto nos casos de Cursos em Parceria, que obedecerão a regra Própria definida no Regimento Geral.

Art. 47 - A Comissão de Graduação terá um Coordenador com mandato de 2 (dois) anos, eleito na forma do Regimento Geral da Universidade, com funções executivas.

Art. 48 - Compete à Comissão de Graduação:

I - propor ao Conselho da Unidade, ouvidos os Departamentos envolvidos, a organização curricular e atividades correlatas dos cursos correspondentes; 
II - avaliar periódica e sistematicamente o currículo vigente, com vistas a eventuais reformulações e inovações, deliberando sobre emendas curriculares observadas as diretrizes curriculares emanadas pelo Poder Público;

III - propor ações ao Conselho da Unidade, relacionadas ao ensino de graduação;

IV - avaliar os planos de ensino elaborados pelos Departamentos;

$\mathrm{V}$ - orientar academicamente os alunos e proceder a sua adaptação curricular;

VI - deliberar sobre processo de ingresso, observando a política de ocupação de vagas estabelecida pela Universidade;

VII - aprovar e encaminhar periodicamente à Direção da Unidade a relação dos alunos aptos a colar grau.

\section{Pesquisa e produção científica}

A UFRGS possui Pró-Reitorias de Pesquisa e de Extensão que tem por objetivo estimular, fomentar e acompanhar as atividades de pesquisa e extensão desenvolvidas pelos professores, técnicos e estudantes. Para tanto, conta com um sistema de auxilios e bolsas de iniciação científica e de extensão. Anualmente a PROPESQ promove o Salão de Iniciação Científica (SIC) para divulgar os trabalhos dos estudantes em projetos de pesquisa e a PROREXT o Salão de Extensão para divulgar os projetos de extensão.

Na Escola de Enfermagem, existe a Comissão de Pesquisa (COMPESQ) e a Comissão de Extensão (COMEX), que atende os dois Cursos existentes (Bacharelado em Enfermagem e Análise de Políticas e Sistemas de Saúde - Bacharelado em Saúde Coletiva).

O encaminhamento dos projetos a COMPESQ ocorre em etapa anterior e obrigatória ao envio do projeto ao Comitê de Ética da UFRGS. Com relação aos grupos de pesquisa, o grupo de pesquisa mais consolidado é o Grupo de Estudos em Saúde Coletiva - GESC, consolidado em 2004 (http://dgp.cnpq.br/buscaoperacional/detalhegrupo.jsp?grupo=0192404JDC3VWP).

No $2^{\circ}$ semestre de 2012, teve inicio o Mestrado em Saúde Coletiva, credenciado pelo CNPq e reconhecido pela UFRGS. Alguns docentes do Curso de Análise de Politicas e Sistemas de Saúde também atuam no já consolidado Mestrado e Doutorado em Enfermagem da UFRGS.

Os demais professores desenvolvem pesquisas na graduação, mas ainda não possuem seus grupos constituídos. Os grupos permitem a participação de discentes da graduação e pós-graduação. No que se refere às publicações científicas, a média de produção é de dois trabalhos anuais por docente nos últimos três anos.

Em relação às produções mais relacionadas à extensão todos os professores permanentes possuem projetos concluídos ou em andamento, em média três projetos anuais por professor.

Entre os trabalhos desenvolvidos destacam-se o Salão de Extensão e a Semana Acadêmica que ocorre anualmente na Semana de Recepção aos Calouros, onde são expostos vídeos, pôsteres e mesas temáticas pelos alunos ao longo do curso.

Os alunos têm várias oportunidades de envolvimento em iniciação científica ao longo de sua permanência no curso, a maioria das quais associadas aos projetos de pesquisas dos docentes do corpo permanente.

Atualmente o curso conta com bolsistas de iniciação científica e bolsistas de extensão. Além do ambiente da Universidade, os alunos podem desenvolver atividade de pesquisa e extensão nos locais parceiros do curso, tais como: o Grupo Hospitalar Conceição, Hospital de Clínicas de Porto Alegre e as unidades de saúde do Distrito Glória/Cruzeiro/Cristal. 


\section{Gabinetes de Trabalho para Professores Tempo Integral}

Os nove docentes de diversas formações do Curso Análise de Políticas e Sistemas de Saúde - Bacharelado em Saúde Coletiva dispõem de duas salas, onde realizam estudos, pesquisas, preparam suas aulas e atendem alunos. Estes são distribuídos na Escola de Enfermagem/ UFRGS do Campus, e todas as salas são equipadas com computador, impressora, ar condicionado, mobiliário e acesso à internet, oferecendo boas condições de trabalho.

\section{Espaço de Trabalho para Coordenação do Curso e Serviços Acadêmicos}

A coordenação do curso Análise de Políticas e Sistemas de Saúde - Bacharelado divide uma sala com a coordenação do curso de Enfermagem junto à secretaria administrativa na Escola de Enfermagem/UFRGS do Campus Saúde, para exercer funções de atendimento aos discentes e docentes. A mesma é equipada com computador, impressora, ar condicionado, mobiliário e acesso a internet, oferecendo boas condições de trabalho. A coordenação conta com o apoio da secretaria de graduação. Este setor possui três secretários e uma técnica de assuntos educacionais para atender os dois cursos da Escola. As reuniões da Comissão de Graduação, do Núcleo Docente Estruturante, entre outras, são agendadas e realizadas na sala de reuniões da Escola de Enfermagem/UFRGS do Campus Saúde.

\section{Sala de Professores}

Existe um planejamento de compra de um prédio para instalação do curso Análise de Políticas e Sistemas de Saúde - Bacharelado em Saúde Coletiva. Neste projeto está contemplada uma sala de professores para o curso Atualmente, o Curso APSS - Bacharelado em Saúde Coletiva dispõe de uma sala para professores e COMGRAD de $12,73 \mathrm{~m}^{2}$.

\section{Salas de Aula}

Para as aulas do curso Análise de Politicas e Sistemas de Saúde - Bacharelado em Saúde Coletiva são utilizadas as salas de aula da Escola de Enfermagem, visto que o curso de enfermagem é diurno e o de APSS é noturno. Durante o dia é possivel utilizar as salas de aula para orientação de alunos e aulas de pós-graduação no curso de Mestrado em Saúde Coletiva. Algumas aulas são desenvolvidas na faculdade de Farmácia (laboratório de parasitologia) e de Psicologia (laboratório de informática), todas dentro do Campus da Saúde da UFRGS.

As salas de aula são adequadas para o bem estar do aluno, iluminadas, ventiladas, equipadas com computadores, equipamento multimídia, ar condicionado ou ventiladores. Além desses espaços de sala de aula, os alunos utilizam os laboratórios específicos de cada campus de acordo com a necessidade da disciplina (laboratório de parasitologia e informática). As aulas práticas são realizadas em locais como laboratório de informática e laboratório de parasitologia. São realizadas visitas técnicas com supervisão de docentes do curso em locais como: conselho municipal de saúde, salas de vacina, Unidades Básicas de Saúde, Centro de Vigilância Estadual e Municipal, Hospitais, Pontos de Cultura, Consultório de Rua, Quilombos Urbanos, Laboratório Central do Estado, Hemocentros, Aterros Sanitários, etc.

\section{Acesso dos Alunos a Equipamentos de Informática}

A Escola de Enfermagem possui dois Laboratórios de Informática, um com 15 e outro com 10 computadores, com acesso à internet para uso dos alunos matriculados atualmente no curso tanto de enfermagem como de Análise de Politica se Sistemas de Saúde - Bacharelado em Saúde Coletiva. O curso possui um Laboratório de Apoio Integrado em Saúde Coletiva (LAISC), com componentes e tecnologias apropriadas para a análise de situação de saúde, geoprocessamen- 
to e georreferenciamento aplicado, informação e comunicação, salas de Situação em Saúde e de videoconferência. Além das atividades de ensino e estágios, tal unidade também serve para atividades de pesquisa, extensão e apoio interinstitucional em Saúde Coletiva. O LAISC está localizado na Escola Técnica da UFRGS, situada na Rua Ramiro Barcelos, 2777, em distância próxima da Escola de Enfermagem.

\section{Bibliografia Básica}

A UFRGS mantém um Sistema de Bibliotecas que abrange 29 bibliotecas setoriais que reúnem um acervo de 693.519 livros (volumes), 14.610 periódicos (títulos) e 78.850 itens de outros materiais (incluem disquetes, $\mathrm{CD}-\mathrm{ROM}$, fitas de vídeo, folhetos, microfichas, fitas cassete, documentos eletrônicos) (UFRGS, Relatório de auto-avaliação Institucional-RAAI, 2009). A política de atualização do acervo de graduação fundamenta-se na aquisição do material bibliográfico (livros impressos) identificado nos planos de ensino das disciplinas. O número de exemplares necessários é calculado com base na média do número de matrículas por disciplina e no status da bibliografia (básica essencial, básica ou complementar, pelo sistema - SABi). A distribuição do material adquirido entre as bibliotecas que compõem o Sistema de Bibliotecas é feita de acordo com os locais, onde são ministradas as disciplinas, de modo que o material bibliográfico impresso fique localizado o mais próximo possivel do aluno e do docente. Desde 2005 a Biblioteca Central vem adquirindo também livros em formato eletrônico para uso na pesquisa e na pós-graduação, o que permite amplo acesso por parte da comunidade, pois o material é liberado para todo o intervalo de IPs da Universidade, incluindo acesso remoto pelo mecanismo de Proxy.

O acervo bibliográfico do curso Análise de Políticas e Sistemas de Saúde - Bacharelado em Saúde Coletiva encontra-se predominantemente na biblioteca da unidade acadêmica da Escola de Enfermagem que cedia o curso e conta com o apoio de bibliotecas de outras Unidades Acadêmicas da Universidade, como Psicologia, Medicina, Farmácia e Educação. A coleção destas bibliotecas faz parte do Sistema de Bibliotecas da UFRGS, ficando assim compartilhados todos os acervos da Universidade - os usuários internos e externos têm acesso a esse Sistema. O acervo é considerado adequado, em quantidade, pertinência, relevância acadêmico-científica e atualização, atendendo dessa forma à bibliografia básica estabelecida nos planos de ensino das unidades envolvidas no curso em avaliação.

Para identificação dos títulos a serem adquiridos, os planos de ensino são coletados junto ao Departamento de Assistência e Orientação Profissional (DAOP) e é feita a verificação no Sistema de Automação de Bibliotecas - SABi, dos títulos já constantes no acervo. É gerado um relatório das disciplinas e a bibliografia correspondente e encaminhado para aquisição. A aquisição ocorre com verbas da Unidade e Universidade e também é alimentado e atualizado com repasse de verba do $\mathrm{MEC}$, doações de professores que publicam nessa área e de editoras especializadas. Atualmente o acervo da biblioteca da Enfermagem curso conta com um total de itens: CDROM 439; DVD 126; Folhetos 1898; SSBD (Títulos de periódicos) 276 Issue (fascículos) 16652; Livros 15580; Vídeos (VHS) 142; Total geral de itens: 35126.

\section{Bibliografia Complementar}

O acervo da bibliografia complementar do curso Análise de Políticas e Sistemas de Saúde - Bacharelado em Saúde Coletiva encontra-se nas mesmas bibliotecas e segue a mesma rotina para aquisição que a bibliografia básica, sendo a prioridade de aquisição, de acordo com a verba disponivel, os exemplares da bibliografia básica. O acervo também é considerado adequado, em quantidade, pertinência, relevância acadêmico- científica e atualização, atendendo dessa forma à bibliografia complementar estabelecida nos planos de ensino das unidades envolvidas no curso em avaliação. Atualmente o acervo da bibliografia complementar do curso conta com 430 exemplares de livros 
a disposição dos alunos. Dividindo este número pela quantidade de alunos matriculados temos 5 livros por aluno.

\section{Periódicos Especializados}

Quanto aos periódicos especializados, indexados e correntes, a biblioteca conta com 314 títulos e 16813 fascículos, sendo 96 títulos correntes e 89 títulos com acesso via Portal de Periódicos Capes e/ou Scielo. O acesso ao portal de periódicos é livre nas dependências da universidade e também em outros computadores fora da UFRGS. Os alunos, professores e funcionários podem configurar seus computadores para acessar os artigos. Além do acervo bibliográfico em papel, a biblioteca da Escola de Enfermagem conta com 5 computadores para acesso ao catálogo on line (sistema SABI) e aos Periódicos CAPES/SCIELO.

\section{Comitê de Ética em Pesquisa}

O compromisso de cumprir com as condições bioéticas de pesquisa motivou a UFRGS na criação do Comitê de Ética em Pesquisa (CEP) e da Comissão de Ética no Uso de Animais (CEUA), ambos responsáveis pelas diretrizes e normas concernentes a todas as pesquisas que envolvem seres humanos ou animais para áreas temáticas como desenvolvimentos de novos fármacos, medicamentos, vacinas e testes diagnósticos. Pesquisas empíricas nas Ciências Sociais (que trabalham com métodos como entrevistas, questionários ou etnografia, etc) também estão sujeitas à aprovação do Comitê de Ética. Os projetos que envolvem algum aspecto bioético devem, após seu registro no Sistema de Pesquisa da UFRGS, ser remetidos à COMPESQ (Comissão de Pesquisa da Unidade), que os encaminhará obrigatoriamente ao CEP ou ao CEUA. O Comitê de Ética em Pesquisa da Universidade Federal do Rio Grande do Sul foi criado em março de 1997, e credenciado junto a Comissão Nacional de Ética em Pesquisa (CONEP) do Ministério da Saúde, desde abril de 1997. O Comitê é um órgão independente, vinculado operacionalmente à Pró-Reitoria de Pesquisa da UFRGS. A atual estrutura do Comitê está plenamente adequada às Diretrizes e Normas de Pesquisa em Seres Humanos do Conselho Nacional de Saúde (item VII da Resolução 196/96). A composição do CEP/UFRGS é multiprofissional e tem como função auxiliar as Comissões de Pesquisa das Unidades da UFRGS na tarefa de acompanhar os projetos de pesquisa realizados pelos seus pesquisadores, alunos e técnicos. A produção do conhecimento científico desenvolvida pelos docentes e alunos do Curso Análise de Políticas e Sistemas de Saúde - Bacharelado em Saúde Coletiva nos projetos e pesquisa, de extensão, nos estágios e nos Trabalhos de Conclusão de Curso é integralmente acompanhada pelo CEP/UFRGS. 


\section{ANEXO}

\section{Grade Curricular}

Curriculo:

Créditos Obrigatórios:

Créditos Eletivos:

Créditos Complementares:

Periodo Letivo:
CURSO DE ANÁLISE DE POLÍTICAS E SISTEMAS DE SAÚDE BACHARELADO EM SAÚDE COLETIVA

158

0

12

$2012 / 1$

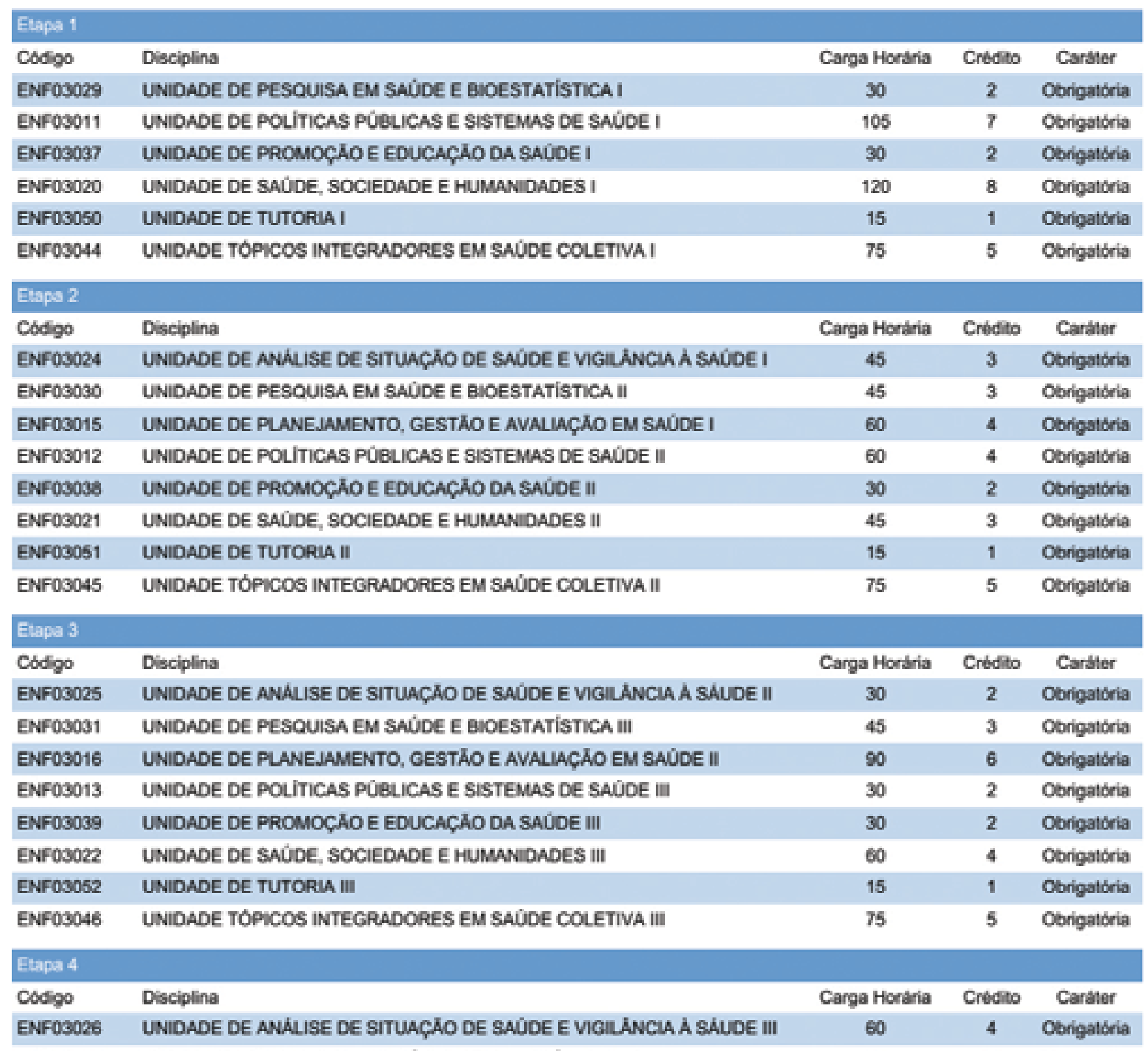




\begin{tabular}{|c|c|c|c|c|}
\hline ENF03032 & UNIDADE DE PESQUISA EM SAOUDE E BIOESTATISTICA IV & 30 & 2 & Obrigatbria \\
\hline ENF03017 & UNIDADE de PLANEJAMENTO, GESTÃo E AVALIAÇ̄̄o EM SAÚde III & 60 & 4 & Obrigatbria \\
\hline ENF03014 & UNIDADE DE POLITICAS PÚBLICAS E SISTEMAS DE SAÚDE IV & 60 & 4 & Obrigatbria \\
\hline ENF03040 & UNIDADE DE PROMOÇAAO E EDUCAÇAOO DA SAÚDE IV & 45 & 3 & Obrigatcria \\
\hline ENF03023 & UNIDADE DE SAÜDE, SOCIEDADE E HUMANIDADES IV & 30 & 2 & Obrigatbria \\
\hline ENF03053 & UNIDADE DE TUTORLA N & 15 & 1 & Obrigatbria \\
\hline ENF03047 & UNIDADE TOPICOS INTEGRADORES EM SAÚDE COLETIVA IV & 75 & s & Obrigatbria \\
\hline \multicolumn{5}{|l|}{ Etapa 5} \\
\hline Codigo & Disciplina & Carga Horatria & Cridito & Carater \\
\hline ENF03027 & UNIDADE DE ANALISE DE SITUAÇĀO DE SAÓDE E VIGILANCIA A SAÚDE N & 90 & 6 & Obrigatoria \\
\hline ENF03033 & UNIDADE DE PESOUISA EM SAŨDE E BIOESTATISTICA V & 45 & 3 & Obrigatbria \\
\hline ENF03018 & UNIDADE DE PLANEJAMENTO, GESTĀOO E AVALLACĀOO EM SAŌOE N & 60 & 4 & Obrigatoria \\
\hline ENF03041 & UNIDADE DE PROMOÇAO E EDUCAÇAO DA SAŨDE V & 90 & 6 & Obrigatbria \\
\hline ENF03054 & UNIDAOE DE TUTORIAV & 15 & 1 & Obrigatbria \\
\hline ENF03048 & UNIDADE TOPICOS INTEGRADORES EM SAÚDE COLETIVAV & 75 & 5 & Obrigatbria \\
\hline \multicolumn{5}{|l|}{ Etapa 6} \\
\hline Codigo & Disciplina & Carga Horaria & Credito & Carater \\
\hline ENF03028 & UNIDADE DE ANALLISE DE SITUACAAOO DE SAŌOE E VIGILANCIA A SAUUDE V & 105 & 7 & Obrigatbria \\
\hline ENF03034 & UNIDADE DE PESQUISA EM SAÓDE E BIOESTATISTICA VI & 60 & 4 & Obrigatbria \\
\hline ENF03019 & UNIDADE DE PLANEJAMENTO, GESTÃO E AVALLAÇĀOO EM SAÚDE V & 60 & 4 & Obrigateria \\
\hline ENF03042 & UNIDADE DE PROMOÇĀO E EDUCAÇĀO DA SAÚDE VI & 60 & 4 & Obrigatbria \\
\hline ENF03055 & UNIDADE DE TUTORIA VI & 15 & 1 & Obrigatbria \\
\hline ENF03049 & UNIDADE TOPICOS INTEGRADORES EM SAÚDE COLETIVA VI & 75 & 5 & Obrigatbria \\
\hline \multicolumn{5}{|l|}{ Etaps 7} \\
\hline \multirow[t]{3}{*}{ Codigo } & Disciplina & Carga Horkia & Cridato & Canater \\
\hline & ESTAGIO CURRICULARI-APS & 300 & 0 & Obrigatbria \\
\hline & TRABALHO DE CONCLUSAO I - APS & 15 & 0 & Obrigatoria \\
\hline ENF03035 & UNIDADE DE PESQUISA EM SAŨdE E BIOESTATISTICA VII & 60 & 4 & Obrigatbria \\
\hline \multicolumn{5}{|l|}{ Etapa 8} \\
\hline \multirow[t]{3}{*}{ codigo } & Disciplina & Carga Horaria & Credito & Carater \\
\hline & ESTAGIO CURRICULAR II - APS & 300 & 0 & Obrigatbria \\
\hline & TRABALHO DE CONCLUSAO $\|$ - APS & 15 & 0 & Obrigatbria \\
\hline ENF03036 & UNIDADE DE PESQUISA EM SAÚDE E BIOESTATISTICA VIII & 60 & 4 & Obrigatobria \\
\hline \multicolumn{5}{|c|}{ Eletiva Facultativa } \\
\hline Codigo & Disciplina & Carga Horatria & Cretdito & Carater \\
\hline MAT02218 & BIOESTATISTICA & 60 & 4 & Adicional \\
\hline B1011417 & INTROOUÇÄO ECOLOGLA & 30 & 2 & Adicional \\
\hline EDU03071 & LINGUA BRASILEIRA DE SINAIS (UBRAS) & 30 & 2 & Adicional \\
\hline Biв03306 & METODOLOGIA DA PESQUISA BIBLIOGRÁFICA & 45 & 3 & Adicional \\
\hline ODO98037 & PRATICAS INTEGRADAS EM SAÚDE - I & 60 & 4 & Adicional \\
\hline PS101003 & PSICOLOGLA APUICADA A SAÚDE & 30 & 2 & Adicional \\
\hline
\end{tabular}





\section{PORTFÓLIO COMO DISPOSITIVO DA \\ AVALIAÇÃO: \\ Aproximações para a definição de novas \\ estratégias de avaliação no curso de bacharelado em Saúde Coletiva da UFRGS ${ }^{1}$}

Alcindo Antônio Ferla

Ricardo Burg Ceccim²

\section{Introdução}

Este documento foi elaborado com o objetivo de ampliar e provocar o diálogo sobre as inovações no projeto pedagógico do Curso de Análise de Políticas e Sistemas de Saúde - Bacharelado em Saúde Coletiva, em particular sobre o uso do portfólio como dispositivo de avaliação no ensino. Constitui-se num esforço de revisão, buscando um formato de ensaio teórico para aprofundamento.

A primeira aproximação para a reflexão sobre o portfólio como dispositivo para a avaliação em educação é reconhecer que há uma diversidade de sentidos, o que constitui uma polissemia de conceitos para tal artefato, tornando necessário fazer avançar a análise para a camada das práticas avaliativas que se estabelecem a partir dele. De toda forma, sua circulação tem crescido no contexto das iniciativas mais ou menos recentes de análise crítica de instrumentos e métodos de avaliação associados às metodologias ativas, às pedagogias problematizadoras ou à aprendizagem inventiva em diversas áreas de formação profissional, sendo apresentado frequentemente como um dispositivo para a construção de conhecimentos e experiências crítico-colaborativas que tomam o processo ensino-aprendizagem como centro, ii .

\section{Uso do portfólio na avaliação}

O uso do portfólio como instrumento de avaliação teve seu início, muito provavelmente, no campo das artes, com profissionais (artistas plásticos, desenhistas, pintores, arquitetos etc.) selecionando e seriando em um suporte físico amostras da sua produção para orientar a avaliação de potenciais consumidores com uma visão geral do seu percurso artístico ${ }^{\mathrm{iii}}$. Sua inclusão como estratégia na educação foi difundida no ensino infantil nos Estados Unidos a partir da primeira metade da década de $1990^{\text {iv, v. }}$

Em um estudo sobre a potência do portfólio como dispositivo de avaliação do ensino na especialização em gestão de políticas públicas e de saúde foram registradas algumas categorias de análise que fortalecem essa reflexão ${ }^{\text {vi. }}$

Uma primeira categoria marcadora dessa potência é a capacidade do dispositivo de descrever os diferentes tempos da aprendizagem: sala de aula e mediação com a prática, no cotidiano do trabalho. Uma segunda categoria marcadora é a capacidade desse dispositivo de tornar visível a transversalidade entre os dois tempos. Além disso, o portfólio constitui visibilidade à dimensão processual da aprendizagem, na medida em que

1 Documento em versão preliminar elaborado por Alcindo Antônio Ferla e Ricardo Burg Ceccim para circulação restrita à Comissão de Graduação do Curso de Bacharelado em Saúde Coletiva como subsídio à formulação de tecnologias avaliativas com base em portfólio. Porto Alegre, 17 de agosto de 2009.

2 Professores do Curso de Análise de Políticas e Sistemas de Saúde - Bacharelado em Saúde Coletiva da Universidade Federal do Rio Grande do Sul. 
o registro permite sucessivas revisões e, portanto, a ressignificação do conhecimento. Além dessas categorias, destaca-se a potencialização da dimensão subjetiva da aprendizagem, a ampliação da potência de intervenção dos estudantes e o caráter matricial dos conhecimentos especializados para a composição de aprendizagens significativas coladas ao cotidiano do trabalho. Por fim, o portfólio tem sido um excelente dispositivo para construir tecnologias de gestão participativa e de intervenção, inclusive trabalhos de conclusão implicados eticamente com a formação e o protagonismo dos sujeitos.

Além das dimensões categorizadas na experiência relatada acima, há evidências na literatura de que o portfólio seja em si uma estratégia de aprendizagem, uma vez que há um expressivo e significativo envolvimento pessoal e acadêmico do estudante na sua confecção, visível na ação de avaliar a produção para selecionar os trabalhos a serem incluídos no portfólio e de descrever seus momentos de aprendizagem, situações que estimulam o "re-significar de seus conhecimentos, e refletir sobre sua história acadêmica"vii.

\section{A dimensão prática: recomendações para uso do portfólio}

Alguns princípios são recomendados para o uso de portfólios no contexto de experiências de ensino problematizador ou por atuação do conhecimento. Entre esses, a compatibilidade do portfólio (como materialidade e como tecnologia avaliativa) com a proposta pedagógica da atividade educativa em que será aplicado. Além desse, citam-se os princípios da pessoalidade (embasado no estudante e na relação singular de aprendizagem deste com o tutor), da auto-implicação (o envolvimento e o comprometimento recíproco dos sujeitos - estudantes e tutores - consigo mesmos e com o outro como dispositivo para o enriquecimento das visões pessoais), da revitalização do conhecimento pela diversidade (pela constatação de que a alteridade com o outro e com a diversidade ampliam os quadros de referência e abrem novos espaços de compreensão dos contextos e atuação futura) e de construção contínua do conhecimento (pela percepção do inacabamento de toda a aprendizagem) ${ }^{\text {viii }}$.

Vantagens e desvantagens vêm sendo associadas ao uso do portfólio em contextos educativos. Em relação às vantagens, são citadas as seguintes:

a oportunidade para um processo reflexivo mais sistematizado e continuado, centrado sobre as múltiplas dimensões da prática; um espaço de questionamento sistemático sobre a prática em situações de trabalho; a promoção do desenvolvimento do formando a partir das suas próprias experiências, motivações e necessidades; a oportunidade para desenvolver processos de auto-avaliação e de autoconhecimento do formando, por meio da [identificação] dos seus pontos fortes e suas fragilidades; e a oportunidade de uma avaliação mais autêntica, mais dinâmica, mas fundamentada e mais participadaix .

o desenvolvimento pessoal e grupal; a aprendizagem reflexiva e crítica e não rotineira, o desenvolvimento de competência de planejamento e da capacidade de pesquisa; a valorização do trabalho do outro; a objetivação da avaliação; a aprendizagem na competição gerida, explicada (...) como sendo a capacidade de, no processo grupal, estudantes e professor lidarem com a competição dentro de fronteiras que permitam que o grupo funcione $^{\mathrm{x}}$. (APÓSTOLO citado em SILVA \& SÁ-CHAVES, 2008).

Em relação às desvantagens, elas aparecem na literatura específica como desafios à implantação e têm duas dimensões: institucional (incompatibilidade entre a proposta pedagógica e o uso do portfólio e falta de suporte institucional para sua implantação) e individual (dificuldades no seu uso pelos tutores e educandos) ${ }^{\mathrm{xi}}$. A dimensão individual decorre, de forma predominante, da falta de familiaridade com a estratégia do portfólio e/ou com mecanismos de reflexão sobre a aprendizagem e se torna visivel, principalmente nas fases iniciais de implan- 
tação, pela invisibilidade do sujeito nas construções textuais, pela ausência de construções textuais reflexivas e pela desintegração entre a forma e o conteúdo das construções textuais. Também decorre de resistências de múltiplas naturezas, em particular pela inibição no uso da expressão verbal e escrita dos sujeitos, que preferem muitas vezes "silenciar o que pensam do que ter que externar seus sentimentos, conhecimentos e crescimentos adquiridos durante sua trajetória acadêmica"xii.

Há, entretanto, um predomínio de avaliações positivas sobre o portfólio e duas questões são colocadas à análise quando ele é tomado como dispositivo de avaliação:

- O que se inclui na designação "portfólio", ou seja, quais são os instrumentos que objetivamente estão inclusos na abordagem do portfólio?

- Quais os usos que se faz do portfólio, ou seja, para quê o portfólio é utilizado e onde esses usos se conectam com o projeto pedagógico da atividade?

Em relação à primeira questão, em que há um predomínio do portfólio como suporte físico, trata-se de um meio material (pasta, arquivo etc.) e/ou virtual (ambiente de aprendizagem, blog etc.) em que são colecionados diferentes instrumentos (auto-avaliação, avaliação de docentes, avaliação de pares, registros pessoais de atividades realizadas, participação em atividades, fichamento de textos, relato de experiências, filmes, músicas, notas pessoais, experiências de aula, trabalhos pontuais etc.). Ou seja, são colecionadas diferentes classes de documentos que tenham capacidade de propiciar evidências do conhecimento construído, das estratégias utilizadas para isso e da disposição do estudante para a aprendizagem ${ }^{\text {xiii }}$. Nessa dimensão do porfólio, têm destaque o fato de se tratar de uma ferramenta para a qual deve ser assegurada a gestão protagônica do estudante, a partir de situações previamente definidas no processo de avaliação, e de assegurar o acesso seletivo ao tutor, que deverá participar da definição de objetivos e metas de aprendizagem, dos instrumentos de avaliação que compõem o portfólio e de registrar registros avaliativos do percurso do estudante.

- As possibilidades que parecem colocadas aqui para a avaliação do Curso de Bacharelado em Saúde Coletiva são:

$\diamond$ Em relação à abrangência:

» Avaliação da aprendizagem: a definição de portfólio como dispositivo para acompanhamento do processo de ensino-aprendizagem dos estudantes, que inclui a memória individual de percurso e a coleção dos diferentes instrumentos utilizados na avaliação semestral das UPPs, dos diferentes instrumentos e técnicas utilizados para avaliação nas atividades de tutoria e das diferentes estratégias - com base nos estudantes - para a avaliação institucional do curso.

» Avaliação Institucional: a definição do portfólio como estratégia avaliativa para o curso, que inclui a coleção dos diferentes instrumentos e estratégias da avaliação institucional e de parte ou do todo dos portfólios individuais.

» Avaliação individual e coletiva: a oportunidade do portfólio para a troca de informações, verificar e refazer pactos de ensino-aprendizagem, processos grupais, mediações com cenários de práticas.

$\diamond$ Em relação à natureza do suporte a ser utilizado:

»O suporte em ambiente virtual (perspectiva institucional futura) e em meio físico (perspectiva mais imediata). Até a preparação de tecnologias informacionais, os estudantes poderiam ser orientados à utilização de uma pasta para arquivamento de todos os instrumentos de avaliação utilizados no semestre e materiais de documentação e registro 
da composição de aprendizagens.

» A inclusão de um "Memorial de percurso" pode significar uma tecnologia avaliativa potente para as atividades de tutoria. Esse caderno/diário deveria conter registros dos estudantes sobre fatos, ações relevantes, experiências e sentimentos relevantes e significativos sobre a aprendizagem construída durante o curso, assim como a auto-avaliação descritiva, informando o estágio do processo de aprendizagem, dúvidas etc.. No memorial, serão feitas anotações e comentários de interface por parte dos tutores, constituindo-se num elemento de reverberação individualizado. Ele também seria utilizado como dispositivo para atividades grupais, como tecnologia de produção em rede.

$\diamond$ Em relação aos diferentes niveis de acesso:

»O acesso irrestrito do estudante ao seu próprio portfólio, para consulta e registros.

»O acesso para professores das diferentes UPPs (como suporte à avaliação em cada semestre, por exemplo, e como registro dessas avaliações para acompanhamento do processo educativo);

»O acesso aos tutores de cada um dos grupos (como suporte à avaliação transversal do percurso em cada semestre e nas diferentes etapas do curso dos estudantes do seu grupo e como registro de notas avaliativas sobre o percurso);

»O compartilhamento nos grupos de tutoria em que os alunos se apresentam/reapresentam periodicamente por meio de seu portfólio e contribuem uns com os outros sobre apreciações, lacunas, conquistas, modos de ver-sentir-agir;

»O acesso à coordenação do curso (como suporte à avaliação institucional e do percurso dos estudantes e como registro de considerações sobre o andamento do curso).

No que se refere à segunda questão, adquire mais relevância o portfólio como tecnologia avaliativa, seja na dimensão formativa ou na dimensão somativa. O portfólio, nesse contexto, adquire o sentido de um organizador qualificado de informações ${ }^{\text {xiv }}$, ou seja, mais do que um repositório de evidências sobre as quais se pode atribuir um juízo de valor, um dispositivo de conversas e um marcador de processos de aprendizagem. Na dimensão formativa, o uso do portfólio permite identificar e equacionar conflitos cognitivos e afetivos, lacunas ou omissões no processo formativo, assim como ruídos do processo ensino-aprendizagem. Na dimensão somativa, ao final de cada etapa do processo, o portfólio pode constituir evidências significativas dos processos e dos resultados da formação, das oportunidades a recompor ou a reengendrar.

- As potencialidades colocadas até aqui para o uso do portfólio no Curso de Bacharelado em Saúde Coletiva parecem indicar:

$\diamond$ Que é um dispositivo importante para disparar as atividades de tutoria e que pode gerar subsidios para aumentar o protagonismo dos estudantes no processo de aprendizagem, podendo gerar evidências para acompanhamento singular da aprendizagem e para o monitoramento do curso.

$\diamond$ Que os portfólios individuais podem ser utilizados em fluxos de trocas estudante e tutor, onde sejam registradas devoluções avaliativas e informações e perspectivas novas para o processo formativo, e em ciclos coletivos e periódicos do grupo de tutoria, onde cada sujeito apresenta o seu portfólio e constrói novas perspectivas a partir da mediação/interação com os demais colegas.

»Em particular, o "Memorial de percurso" / Caderno de campo da aprendizagem" poderia ser utilizado como o registro de narrativas sobre situações práticas do processo ensino-aprendizagem. Planejado para ciclos semestrais, poderia conter quatro nature- 
zas de registros: a) relativos às situações de aprendizagem em sala de aula; b) relativos às situações de prática em outros ambientes de aprendizagem e situações vividas; c) relativos às atividades em grupo na tutoria; e d) relativos aos processos avaliativos. $\mathrm{O}$ acompanhamento dos registros pelos tutores poderia considerar as seguintes dimensões, também úteis para o portfólio como um todo ${ }^{\mathrm{xv}}$ :

- Técnica, relativamente à descrição correta, detalhada e criativa das situações registradas, tendo os retornos avaliativos do tutor a capacidade de provocar a observação, a criatividade, a documentação e o registro;

- Crítica, relativamente à capacidade de incluir outros elementos na narrativa, para além da descrição, como causas, conseqüências e significados percebidos dos fenômenos estudados e/ou idéias de pesquisas complementares em bases científicas ou em outros informantes. Os retornos avaliativos seriam relativamente à capacidade de refletir sobre o papel dos contextos na produção dos fatos observados, as funções e papéis desempenhados pelos diferentes sujeitos, sobre concepções que sustentam as decisões que interferem no contexto observado e sobre outras possibilidades que podem ser produzidas a partir de novas concepções.

- Metacrítica, relativamente à capacidade de refletir sobre si próprio no processo de ensino-aprendizagem. Os retornos avaliativos deveriam ter capacidade de produzir estranhamentos em relação às atuações, à compreensão e às concepções subjacentes à narrativa.

$\diamond \mathrm{O}$ resultado sistematizado desse processo pode ser registrado e/ou compartilhado pelos tutores com a coordenação das UPPs e do curso para fortalecer as estratégias de acompanhamento.

$\diamond$ A implantação do portfólio poderá ser feita progressivamente, iniciando-se com a dinâmica da tutoria e expandindo-se progressivamente, à medida da adesão de professores e UPPs.

» A tutoria poderia iniciar-se com a apresentação do portfólio aos alunos e a pactuação da dinâmica de uso do portfólio. Durante o semestre, poderiam ser organizadas sessões de devolução individuais (por meio do caderno de campo e/ou de registros em meio eletrônico, bem como atividades presenciais entre tutor e estudante) e sessões de devolução coletiva (apresentação de portfólios individuais e debate nos grupos de tutoria). Essa dinâmica poderia estimular a produção de um portfólio do grupo para as atividades do semestre, provocando à produção criativa e coletiva.

» O grupo de tutores poderia ocupar-se, durante o semestre, de avançar na discussão e proposição de metodologias, critérios e indicadores para avaliação do portfólio nos semestres subsequentes.

$\checkmark$ As primeiras funcionalidades do ambiente virtual poderiam ser: a visualização pelo tutor do percurso (UPPs/temáticas cursadas e avaliações) dos participantes do seu grupo de tutoria e a organização de ambientes virtuais de grupos de tutoria (com ferramentas de grupos de discussão, fóruns, postagens de arquivos magnéticos de diferentes formatos e tamanhos). Na sequência, poderiam ser desenvolvidas ferramentas de webfólio por aluno, com capacidade de acumular registros de diferentes semestres.

\section{Orientações para começar o portfólio}

Como se verificou anteriormente, a potência avaliativa do portfólio mais compatível com o projeto pedagógico do Bacharelado em Saúde Coletiva é a de um organizador qualificado de infor- 
mações, uma tecnologia, portanto, mais do que uma metodologia de avaliação. Sendo assim, a proposta de que o mesmo adquira um certo modo de apresentação, formulada nesse item, pretende também constituir-se como objeto de pensamento e de debate. Mas parte da necessidade de que o nivel de abstração da argumentação aqui apresentada não seja marcador do pensamento acerca de sua exequibilidade. Segue uma proposição, para iniciar a conversa:

\section{Etapa da Abertura}

1. Personalização: a capa deve expressar a ti, tua "personalidade" e teu jeito de ver e de querer mostrar as coisas.

2. Primeira página: faça tua apresentação, teu nome e o lugar onde estás inserido (use a forma de itens, narrativa ou uma mescla de ambas).

3. Memorial 1 - narrativa: apresente uma narrativa de tua chegada ao curso, o que espera dele e outras coisas que consideres relevante constar sobre a tua escolha e a tua chegada, bem como sobre o acolhimento e começo.

4. Memorial 2 - análise de competências: que competências tuas trazes ao curso (para o coletivo que se forma/formará), que competências pensas que esta profissão te ofertará, que competências - em especial - queres desenvolver em teu perfil profissional.

\section{Etapa da Documentação}

1. Anotações de aula: ao término de cada aula faça um balanço descritivo da mesma, expondo os conteúdos desenvolvidos (os explicitados e os intercorrentes ou que emergiram para ti), tuas dúvidas, opiniões e reações relativas ao(s) tema(s). Use a forma de itens (com o respectivo título), uma narrativa breve ou um esquema, acrescentando informes qualitativos ou de sentido.

2. Leituras de texto: a orientação é a de uma Ficha de Leitura, que passa a ser solicitação obrigatória de avaliação do percurso de aprendizagem/implicação e uma Analítica de Leitura. Quando houver mais de um texto para a mesma aula ou conteúdo específico, fica a critério do estudante escolher 1 ou mais textos (máximo 2 "laudas").

- Ficha de Leitura: identificação bibliográfica completa, alguma abordagem sobre quem é o autor, alguma referência sobre o que versa o texto (análise temática), relato das idéias centrais aportadas pelo texto, sinopse do conteúdo, síntese das apreensões e fechamento, com recomendações, sugestões e críticas (outras leituras, questões da prática, questões de si, questões à aula etc.).

- Analítica de Leitura: comentários do leitor, colocando o grau de dificuldade na leitura, as aproximações ou não com a prática pessoal, os conceitos que não conseguiu entender e como o texto te fez reagir, além de outras coisas que achares relevante ao tecer a apreciação do texto. No mínimo, tente responder a três considerações: a) tomando teus interesses de estudo, pesquisa ou profissionais, o que o texto te fez pensar e que não pensavas antes; b) o quê, dentre daquilo que já pensavas, o texto fez repensar/rever/reconsiderar; c) aspectos com os quais concordas, mas vê dificuldades de implementação (dizendo o porquê) ou dos quais discordas (dizendo o porquê).

3. Tutoria: todas as atividades de tutoria devem conter registro narrativo no portfólio, sendo desejável a anotação de dificuldades e as perspectivas abertas a partir do desenvolvimento da atividade.

4. Atividades complementares do ensino: todas as atividades de campo, pesquisa, extensão ou indicadas à exploração do conhecimento pelos professores deverão dispor de registro no portfólio com uma analitica sobre sua execução. 
(1)

5. Anexos: podem ser anexadas ao portfólio imagens, fotografias, letras de música e poesias, entre outras "figuras de imagem", além de trechos de falas ouvidas na rua ou na sala de aula, com a função de ilustrar tempos/periodos/cenários/sentidos relativos ao que foi abordado.

6. Apêndices: agregar ao portfólio textos lidos ou recebidos, provas, recortes de imprensa, trabalhos entregues e/ou devolvidos pelos professores ou relativos às atividades de ensino, como uma "documenta" (provimento de documentos).

\section{Observações orientadoras}

1. O portfólio será uma compilação da produção elaborada pelo estudante ao longo do curso. Nesse instrumento deverão constar reflexões (analitica de situações, textos, aulas), sentimentos, relatos de ação e registro de escutas/observações, além de considerações e ponderações relativas a dificuldades, limitações, potencialidades e destaques. Os portfólios não serão iguais entre si, pois expressarão a forma com que cada estudante interagiu com o conhecimento e como o sistematizou. O portfólio é o registro/documento da implicação.

2. A atividade que constar em apêndice não precisará de replicação/reedição/repetição no "documento principal". Neste, constará o registro "de percurso" relativo à atividade, indicando a existência do apêndice e as considerações/ponderações pertinentes (numerar os apêndices citados, viabilizando sua localização por inserção seqüencial).

3. Qualquer impasse deve ser levado ao tutor ou, preferencialmente, ao grupo de tutoria, onde as decisões implicarão orientação coletiva para os participantes do grupo, mas, diante de dúvidas, deve-se lembrar que este é um documento autoral, portanto, vale a orientação básica: o jeito de ver ou de querer mostrar as coisas, de cada estudante.

4. Elaboração de narrativas no portfólio: A narrativa, no portfólio e para a tutoria, deve funcionar como uma "reconstrução do vivido", dotando de vivências de sentido os fatos narrados, assim como informando ao leitor ou ouvinte sobre esse processo. Ao narrar, o autor fará "recortes", gerando destaques ou ênfases para etapas, processos ou instâncias, preocupando-se em dar acesso contextualizado ao leitor ou ouvinte e permitir o conhecimento de cenários dos quais o leitor ou ouvinte não participa ou não participou.

Dependendo do conteúdo da narrativa, diferentes formas podem ser escolhidas para a melhor expressão de sua informação. A forma narrativa pode ser substituída pela forma de uma crônica, de uma piada, de um conto, de uma peça teatral, de uma coreografia ou de uma fábula, dentre outras. A narrativa também pode vir acompanhada ou mesmo entremeada de falas e pensamentos dos atores envolvidos, possibilitando (e buscando) que os diversos pontos-de-vista (o cruzamento ou triangulação de saberes) envolvidos sejam expressos. Então, não se trata de um documento frio ou sem implicação, ao contrário, é autoral, vivo, encarnado.

As narrativas, no portfólio, devem corresponder às experiências ligadas à aprendizagem em Saúde Coletiva, seja no curso de graduação, na vivência universitária atual ou nas vivências cotidianas onde seja possivel essa correlação. É relevante informar/demonstrar ações e dedicações que exigiram esforço especial ou reflexões da parte do autor ou da sua turma e cujas questões envolvidas possam encontrar eco na condução do curso.

Uma boa narrativa transpira dúvidas, emoções e problematização; faz transparecer o cenário onde ocorreram os fatos; é permeável às diferentes posições dos diversos atores e mobiliza os leitores ou ouvintes a realizarem problematizações, estimulando a produção de conhecimentos novos ou por outramento, a partir de uma vivência/história compartilhada.

Alguns cuidados são importantes com a apresentação escrita, pois se trata de material à difusão por pares: o texto deve possuir uma redação clara, que desperte o interesse e que seja de fácil leitura. É necessária a digitação (se manuscrito, tomar cuidado para com a elevada 
legibilidade) e uma formatação que permita guarda em acervo de documentos, datando e anotando, necessariamente, os respectivos dados de identificação e pertencimento às UPPs. Tudo que for traço a mão, sejam palavras, simbolos, desenhos ou sinalizações, entre outros, é apropriado segundo o critério da "comunicação". Não deve haver nenhum tipo de censura fora da intenção comunicativa em "cenários intelectuais", pois a maturidade expressiva também é uma das competências a desenvolver pelo portfólio e grupo tutorial, motivos da introdução dessa prática pedagógica.

Em cada tutoria será selecionada uma narrativa a ser lida e comentada no grupo tutorial. Escolhida na hora (sem agendamento prévio), a narrativa será trabalhada ao máximo pelo tutor e colegas.

\section{Avaliação/Revisão dos Portfólios}

A avaliação geral do portfólio pertence ao tutor e ao grupo de tutoria, devendo contar com duas estratégias de interação: a) uma planilha de critérios pactuada com o Grupo Tutorial (Proposta no Anexo); e b) indicações ao longo da leitura, como "notas do leitor". O que for relativo a cada professor do curso pode contar com sua leitura e apreciações (anotações, pareceres, indicações), a pedido do próprio professor, do aluno ou do tutor.

\section{REFERÊNCIAS}

i SILVA, R.F.; SÁ-CHAVES, I. Formação reflexiva: representações dos professores acerca do uso do portfólio reflexivo na formação de médicos e enfermeiros. Interface: Comunicação, Saúde e Educação, v. 12, n. 27, p. 72134, out./dez. 2008. Disponivel na internet: http://www.scielo.br/pdf/icse/v12n27/a04v1227.pdf. Consultado em $17 / 08 / 2009$.

ii TANJI, S.; SILVA, C.M.S.L.M.D.. As potencialidades e fragilidades do portfólio reflexivo na visão dos estudantes de enfermagem. Rev. Enf. UERJ, v. 16, n. 3, pág. 392-8, jul/set 2008. Disponivel na internet: http://www.bvsintegralidade.icict.fiocruz.br/lildbi/docsonline/1/6/161-v16n3a16.pdf. Consultado em 16/08/2009.

iii HERNÁNDES, F.. Transgressão e mudança na educação. Porto Alegre: Artmed, 1998.

iv Tanji \& Silva, op cit.

v CUNHA, I.C.K.O.; SANNA, M.C.. Portfólio como estratégia de avaliação de desempenho de integrantes de um grupo de pesquisa. Rev. Bras. Enfermagem, v. 60, n. 1, pág. 73-6, jan/fev/ 2007. Disponivel na internet: http:// www.scielo.br/pdf/reben/v60n1/a13v60n1.pdf. Consultado em 16/08/2009.

vi FERLA, A.A.; BERTELE, E.; DE DAVID, M.; BATISTA, M.V.. O portfólio avaliativo como dispositivo para a gestão de processos de educação permanente em saúde. $8^{\circ}$ Congresso da Rede Unida, 2009. (Mimeo). Pág. 1.

vii Tanji \& Silva, op. cit. Pág. 394.

viii Silva \& Sá-Chaves, op. cit.

ix Grilo \& Machado, 2005; citados em Silva \& Sá-Chaves, 2008. Pág. 723-4.

x Apóstolo, 2005; citado em Silva \& Sá-Chaves, 2008. Pág. 724.

xi Tanji \& Silva, op. cit.; Silva \& Sá-Chaves, op. cit.

xii Tanji \& Silva, op. cit. Pág. 393.

xiii Tamji \& Silva, op. cit..

xiv MOROSINI, Marília Costa, LEITE, Denise B. C. Avaliação Institucional como um organizador qualificado: na prática é possivel repensar a Universidade? In: SGUISSARI, Valdemar. Avaliação universitária em questão: reformas do Estado e da educação superior. Campinas, São Paulo: Editora Autores Associados, p. 123-148, 1997.

xv Com base na experiência relatada por Silva \& Sá-Chaves, op. cit.. 


\section{Avaliação dos portfólios}

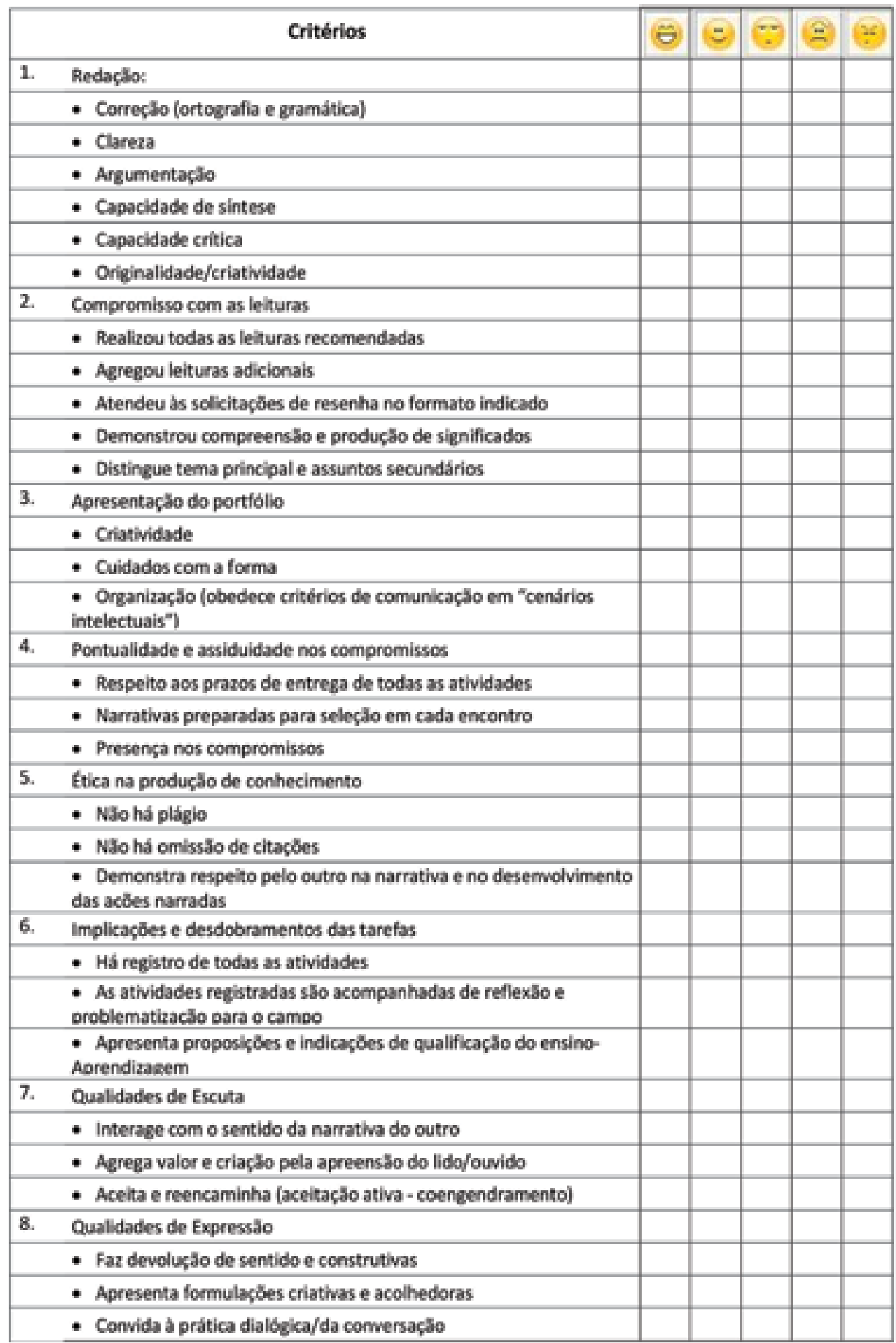





\section{A UNIDADE DE PRODUÇÃO PEDAGÓGICA COMO ATIVIDADE DE ENSINO NO CURSO DE ANÁLISE DE POLITICAS E SISTEMAS DE SAÚDE}

Alcindo Antônio Ferla²

\section{Introdução}

Este texto foi elaborado em subsídio ao debate na Comissão de Graduação do Curso de Análise de Políticas e Sistemas de Saúde com o objetivo de propor ao Conselho de Ensino, Pesquisa e Extensão (CEPE) da UFRGS a criação de "Unidades de Produção Pedagógica" como modalidade de atividade de ensino para atender às necessidades de cursos com nova concepção curricular. Parte do fato de que a organização de inovações na formação necessita de outros formatos das atividades de ensino para sua efetivação e das disposições do projeto pedagógico do Bacharelado em Saúde Coletiva que designa por "Unidades de Produção Pedagógica" as atividades de ensino que o compõe. Foi realizado com base numa revisão das disposições legais na legislação federal e nas normas institucionais da UFRGS para o ensino de graduação e de um debate sobre as inovações no ensino.

\section{Considerações legais}

- A Lei de Diretrizes e Bases da Educação (Lei Federal n 9.394/96) estabelece em seu Art. 53, que cabe às universidades, a fixação dos currículos dos cursos e programas (Inciso II), por meio de seus colegiados e em garantia à autonomia didático-científica (§ único, Inciso III);

- O Regimento Geral da UFRGS estabelece que "o ensino de graduação e pós-graduação será organizado sob a forma de disciplinas e ministrado na modalidade de cursos ou outros conjuntos sistematizados de disciplinas ou atividades" (Art. 109). Estabelece ainda:

$\diamond$ Que a disciplina "caracteriza-se como programação particular de conteúdos integrantes de uma área definida do conhecimento, a ser ministrada em determinado periodo de tempo, atendendo ao Calendário Escolar da Universidade e correspondendo a determinado número de créditos" ( $\S 1^{\circ}$, Art. 109), que tenham uma equivalência mínima de um crédito a cada 15 horas-aula (Art. 111);

$\diamond$ Que as "disciplinas poderão integrar conteúdos de diferentes áreas de conhecimento, atendendo aos principios da interdisciplinaridade" (§ $2^{\circ}$, Art. 109);

$\diamond$ Que a carga horária de cada disciplina "é a soma total de horas-aula destinadas às atividades didáticas, integradas no plano da disciplina, desenvolvidas sob a supervisão de professor responsável, em aulas teóricas, teórico-práticas e práticas, inclusive fora do âmbito

1 Texto elaborado em subsídio ao debate, na Comissão de Graduação do Curso de Análise de Políticas e Sistemas de Saúde, com a finalidade de subsidiar proposta ao Conselho de Ensino, Pesquisa e Extensão (CEPE) da UFRGS a criação de "Unidades de Produção Pedagógica" como modalidade de atividade de ensino para atender às necessidades de cursos com nova concepção curricular. Porto Alegre, outubro de 2009.

2 Professor do Curso de Análise de Políticas e Sistemas de Saúde - Bacharelado em Saúde Coletiva da Universidade Federal do Rio Grande do Sul. 
da Universidade" ( $\$ 2^{\circ}$, Art. 110);

- O Regimento Geral da UFRGS define que o CEPE tem competência para estabelecer as normas específicas de organização dos cursos (Art. 112);

- A Resolução n ${ }^{\circ}$ 17/2009, do CEPE/UFRGS, define como atividades de ensino: disciplinas, estágios, estágios de docência e trabalhos de conclusão (Art. 30);

- O projeto de criação do Curso de Bacharelado em Saúde Coletiva, discutido e aprovado nas instâncias internas da UFRGS, previu "uma estrutura curricular assentada em Unidades de Produção Pedagógica (UPP), cognição e sensibilidades, construídas por um conjunto de domínios do conhecimento que deverão ser desenvolvidos sob um encadeamento construtivo", configuradas para serem desenvolvidas de forma transversal e programada ao longo do curso.

\section{Inovações na formação}

A inovação nas estratégias de formação, tanto em termos de currículo como de práticas pedagógicas e cenários de ensino-aprendizagem, é uma questão de grande atualidade nas políticas de educação e nas diretrizes institucionais das organizações que atuam na área da educação e em áreas de interface. Em resposta às disposições da Lei de Diretrizes e Bases da Educação e aos processos sociais que buscam novos padrões de qualidade para a educação no Brasil, experiências inovadoras de ensino nos mais diversos âmbitos procuram materializar a disposição de promover "o pleno desenvolvimento do educando, seu preparo para o exercício da cidadania e sua qualificação para o trabalho" (LDB, Art. $2^{\circ}$ ) e, mais do que isso, materializar os princípios da "liberdade de aprender, ensinar, pesquisar e divulgar a cultura, o pensamento, a arte e o saber" (LDB, Art. $3^{\circ}$, Inciso II), da "valorização da experiência extra-escolar" (LDB, Art. $3^{\circ}$, Inciso X) e da "vinculação entre a educação escolar, o trabalho e as práticas sociais" (LDB, Art. $3^{\circ}$, Inciso $\mathrm{XI}$ ). Essas disposições criam desafios à experimentação e à avaliação de novas tecnologias de ensino, em particular para os cursos de graduação.

Especificamente no campo da saúde, que tem diretrizes claramente voltadas à mudança no ensino da graduação para a quase totalidade das profissões e emitidas em acordo entre entidades governamentais das áreas de saúde e educação, de órgãos de controle social nessas áreas e de representação profissional, há conhecimentos sistematizados sobre os processos de mudanças e de sua avaliação. As tendências contemporâneas de mudanças no ensino têm, nessa área, mais do que um campo de experimentação. É uma área que tem produzido tecnologias para ampliar o tônus de mudanças na educação das profissõesi. Entre os aspectos das mudanças que mobilizam parte significativa dos estudos disponíveis, a organização curricular, entendida como o modo de distribuir e produzir interfaces entre as atividades de ensino durante o período da formação com base nas orientações dos projetos pedagógicos dos cursos tem um destaque importante ${ }^{\mathrm{ii}}$ iii. Esse destaque deriva, em grande medida, das dificuldades em constituir currículos suficientemente flexíveis para responder aos novos desafios de atuação das profissões no campo da saúde, para responder às diretrizes e políticas nessa área e da educação, para gerar mobilização interna nas instituições de ensino capazes de produzir mudanças também nesse nivel e para fomentar articulações internas aos próprios currículos, que acenem para a superação do modelo disciplinariv, v e um novo plano de interação com o mundo das práticas e os cenários de aprendizagem ${ }^{\text {vi }}$. Ou seja, a organização curricular, seus efeitos no cotidiano do ensino, a integração entre as atividades de ensino que o estruturam e a integração que permitem com o mundo do trabalho são desafios importantes para as inovações na educação das profissões da saúde na contemporaneidade. 


\section{curso de Análise de Políticas e Sistemas de Saúde}

A partir de referenciais teórico-conceituais e político-filosóficos presentes no ensino da saúde, foi elaborada e aprovada a proposta pedagógica para o curso de graduação em Análise de Politicas e Sistemas de Saúde - Bacharelado em Saúde Coletiva, que está assentada na construção de um Currículo Integrado, organizado por Unidades de Produção Pedagógica (UPP), articuladas para o desenvolvimento e produção de conhecimentos interdisciplinares $\mathrm{e}$ de implicação ética com os resultados em saúde.

A unidade curricular denominada de UPPs é definida por um conjunto de domínios do conhecimento e de capacidades que deverão ser desenvolvidos sob um encadeamento construtivo por meio de atividades de ensino diversificadas. Nesta perspectiva, tanto o ensino quanto a aprendizagem traduzem uma vivência de integração das atividades como ato formativo ao longo da UPP, mostrando que formador e aluno estão presentes nas diferentes etapas do seu desenvolvimento. Assim, as Unidades de Produção Pedagógica (UPP) são articuladas de forma longitudinal e seqüencial na proposta de currículo integrado para o desenvolvimento e produção de um conhecimento interdisciplinar. Essa proposta de organização curricular se estrutura a partir do pressuposto da educação permanente em saúde, nos termos em que se tornou política pública no Sistema Único de Saúde, e pretende ser agregadora de áreas e unidades acadêmicas dentro da universidade. A integração deve se dar com os departamentos gestores das cargas horárias dos Docentes que atuarão no curso.

Cada UPP corresponde a um agregado dos conteúdos e práticas (núcleo de saberes) de domínio do profissional da saúde pública no exercício da análise de políticas e sistemas de saúde (exercício das funções profissionais em saúde pública). Assim cada UPP corresponde, também, à gestão docente colegiada desse agregado de conteúdos e práticas. Isto quer dizer que a gestão do curso se assenta principalmente sobre a sua produção pedagógica junto aos alunos e não sobre a gestão administrativa da educação (gestão das cargas horárias, número de créditos, distribuição dos encargos etc.).

Trata-se, portanto, de uma atividade de ensino que difere das já reconhecidas por sua natureza predominantemente interdisciplinar e intimamente associada aos núcleos de conhecimentos e práticas requeridos ao exercício profissional, mas também pela modalidade de gestão, no formato de gestão colegiada, das práticas pedagógicas que a constituem.

$\mathrm{Na}$ medida em que cada UPP é um colegiado de docentes, agregados pelo compartilhamento solidário e co-responsável do ensino de um núcleo de saberes, deverá gerir o desenvolvimento das aprendizagens desse núcleo de saberes junto aos alunos, mas também junto ao desenvolvimento docente permanente e junto à condução da educação no formato de um curso de graduação. As UPP têm um docente gestor indicado pelo agregado de docentes do respectivo núcleo de saberes, esse agregado de professores é proveniente de quaisquer Departamentos envolvidos com o curso.

Além da gestão colegiada, a avaliação contínua e o monitoramento são desenvolvidos no interior das UPPs e pela Comissão de Graduação, fortalecendo a articulação entre as práticas cotidianas no interior do curso, o currículo e as definições do Projeto Político-Pedagógico aprovado. Ao término do primeiro semestre do curso, graças a essa ação de gestão, constatou-se a necessidade de nuclear, em duas novas UPPs, atividades de tutoria e parte dos seminários integradores previstos inicialmente no interior das UPPs com maior carga horária em cada semestre. Assim, já foi encaminhada às instâncias superiores da UFRGS a criação das UPPs de Tutoria e de Tópicos Integradores em Saúde Coletiva, essa na modalidade EAD. O currículo do curso de Bacharelado em Saúde Coletiva, que é predominantemente composto por atividades de ensino Unidades de Produção Pedagógica, contará com as seguintes: 
- Unidade de Politicas Públicas e Sistemas de Saúde: atividades de ensino envolvendo domínios de conhecimento como teoria política, políticas públicas; história da saúde, institucionalização das práticas; história da organização do sistema de saúde no Brasil; reforma sanitária; comparação de sistemas de saúde; saneamento, urbanização e meio ambiente; políticas e programas de saúde; organização do sub-setor de saúde suplementar e suas estruturas de regulação; saúde suplementar.

- Unidade de Planejamento, Gestão e Avaliação em Saúde: atividades de ensino envolvendo dominios de conhecimento como teoria das organizações; planejamento e gestão de políticas e gerenciamento de serviços e sistemas de saúde; estratégias e modelos tecnoassistenciais; informática e informação em saúde; gestão do trabalho e da educação na saúde; controle, monitoramento e avaliação em saúde; auditoria e regulação em saúde; economia da saúde e avaliação econômica no setor saúde; avaliação de políticas de serviços, de programas e de ações no setor da saúde; avaliação de tecnologias em saúde; ciência, tecnologia e inovação em saúde.

- Unidade de Saúde, Sociedade e Humanidades: atividades de ensino envolvendo domínios de conhecimento como antropologia da saúde; sociologia da saúde; gênero, raça e diversidades humanas na formulação, condução e apreciação de ações do setor da saúde; legislação e direito em saúde; participação da população e controle social nos serviços e sistemas de saúde; desenvolvimento ambiente e saúde; geografia humana de interesse ao setor da saúde; arte, cultura e saúde; ética e bioética na atuação em saúde e na produção de conhecimentos.

- Unidade de Análise de Situação de Saúde e Vigilância à Saúde: atividades de ensino envolvendo domínios de conhecimento como epidemiologia; medidas e indicadores em saúde coletiva; estudos e intervenções em epidemiologia; vigilância epidemiológica, ambiental e sanitária; vigilância nutricional e segurança alimentar; vigilância em saúde; saúde do trabalhador; práticas de biossegurança; análise de risco e vulnerabilidade; análise de situação de saúde; demografia; geoprocessamento; carga de doença e determinantes em saúde.

- Unidade de Pesquisa em Saúde e Bioestatística: atividades de ensino envolvendo domínios de conhecimento como tecnologias de busca e uso da informação científica e bibliográfica em saúde; pesquisa e produção de conhecimento em saúde; bioestatística; métodos de pesquisa qualitativa em saúde; métodos gráficos; ética em pesquisa; divulgação científica e tecnológica em saúde; leitura de artigos científicos e busca de evidências técnico-científicas.

- Unidade de Promoção e Educação da Saúde: atividades de ensino envolvendo domínios de conhecimento como educação e comunicação; educação permanente em saúde e educação de profissionais de saúde; educação popular em saúde; práticas multiprofissionais e trabalho em equipe; programas/politicas de saúde para grupos populacionais, culturas urbano e rural; ciclos de vida e necessidades em promoção da saúde; redes sociais e proteção de saúde, movimentos sociais por saúde, espaço e ambientes em saúde; integralidade em saúde; qualidade de vida; saúde mental coletiva; escuta pedagógica das práticas de saúde; pedagogias dos processos coletivos.

Além das Unidades de Produção Pedagógica aprovadas no projeto inicial do curso, foram encaminhadas duas novas UPPs no decorrer de sua implantação, que são as seguintes:

- Unidade Tópicos Integradores em Saúde Coletiva: esta Unidade, a ser implementada na modalidade de EAD, buscará desenvolver, em cada semestre, temas transversais às diferentes UPPs, buscando integrar os diferentes conteúdos aos conhecimentos e práticas da Saúde Coletiva que constituem a base das competências e habilidades a serem desenvolvidas na seqüência do curso. A integração entre eixos disciplinares em campos de atuação é 
argumento central na construção das UPPs, conforme o projeto político-pedagógico do curso. A singularidade desta UPP é a produção de atravessamentos e transversalidades entre as UPPs ofertadas em cada semestre com dimensões da prática profissional nos sistemas e serviços de saúde. A carga horária da modalidade EAD, que já compõe as estratégias de ensino no projeto político pedagógico do Curso, será totalmente utilizada nesta UPP. A inovação curricular se mostra necessária neste momento de implementação do curso, uma vez que apenas com a previsão de alcançá-la com atividades a serem realizadas em uma das UPPs nas quais estava vinculada não se mostrou com suficiente potência. Assim, a Comissão de Graduação do Curso de Bacharelado em Saúde Coletiva optou, após a análise em maior profundidade, na proposição desta nova UPP de forma a garantir a transversalidade prevista.

- Unidade de Tutoria: as atividades de tutoria, propostas no Currículo do Curso de Bacharelado em Saúde Coletiva, compõem a estratégia principal de construção de habilidades e competências com densa reflexão sobre a prática e a produção de conhecimentos associados às mesmas, assim como à avaliação de habilidades desenvolvidas. Da forma como foi prevista no projeto político-pedagógico, essa modalidade de atividades constituiu dificuldades operacionais que comprometem a potência prevista inicialmente, em particular sobrecarga em uma única UPP, o impedimento à participação de estudantes não matriculados nessa UPP específica e problemas para o registro da responsabilidade pedagógica dos docentes na nucleação de grupos nos quais é viável e produtiva a realização dessa modalidade. Para superar o problema constatado e potencializar a estratégia da tutoria, a Comissão de Graduação do Curso de Bacharelado em Saúde Coletiva optou pela criação desta UPP, de forma a garantir singularidade no desenvolvimento e na avaliação do estudante no processo do ensino-aprendizagem em pequenos grupos.

Como a denominação de Unidades de Produção Pedagógica não encontra correspondente nos registros acadêmicos adotados pela UFRGS, optou-se por denominá-las de "disciplinas" no sentido de adequá-las ao sistema usual de registros. Mas essa opção encontrou limites importantes no cotidiano da gestão do curso e novos limites se apresentam na medida em que o curso avança. É importante tomar esses limites não como obstáculos de difícil superação, o que poderia suscitar alternativas de recuo e revisão mais tradicional do projeto, ou como aprendizado capaz de constituir novos patamares de decisão nas políticas de organização acadêmica da UFRGS. O grupo de docentes envolvido no Curso de Bacharelado em Saúde Coletiva aposta fortemente nessa perspectiva, inclusive pelas contribuições que esta área tem produzido no ensino e com base no acúmulo e nas referências de inovação que a UFRGS vem produzindo para as práticas de ensino.

Considerando-se a complexidade e especificidade do campo da Saúde Coletiva, a formação no curso de bacharelado da área deve ampliar a articulação entre os diferentes cursos da área da saúde e cursos em interface intersetorial com a saúde, induzindo o desenvolvimento e a avaliação de iniciativas inovadoras de ensino com a qualificação da capacidade de ensinar da instituição, inclusive pela mobilização do protagonismo dos estudantes. Está nessa perspectiva a ampliação e integração do ensino com cenários do sistema de saúde, particularmente do sistema público de saúde, e a sua vinculação com as necessidades e demandas emanadas desse sistema, especialmente na Região Sul, de modo a fortalecer o padrão de compromisso ético da Universidade - e dos profissionais que ela forma - com a sociedade e com a qualificação da saúde nos âmbitos individual e coletivo. Essas orientações impõem a consideração das transversalidades da área, subáreas e domínios de conhecimento, o uso de metodologias interacionistas e da filosofia construcionista, a interdisciplinaridade, a integralidade e a delimitação da área da Saúde Coletiva como campo de atuação profissional. 
A metodologia interacionista, a filosofia construcionista e a educação permanente em saúde constituem a orientação pedagógico-educacional da formação graduada em Análise de Políticas e Sistemas de Saúde - Bacharelado em Saúde Coletiva, tanto pelo setor de aplicação que se propõe à produção crítica e comprometida ética e politicamente com as necessidades sociais por saúde, quanto pela área do conhecimento que se propõe à revisão de conceitos, valores e práticas, construção e reconstrução de sentidos e linguagens e criação e recriação de práticas. São também orientações para cada uma das UPPs.

Nesse sentido, a formação graduada deve proporcionar aprendizado cognitivo e sensivel, possibilitando o protagonismo dos atores no processo de construção do conhecimento e da formulação e implementação dos atos de saúde.

O interacionismo, a construção e a educação permanente em saúde pressupõem o constante questionamento dos fatos ou fenômenos, compreendendo-os nos seus contextos de produção e engendramento social, histórico, lingüístico, de ação e de atuação, propondo sentidos e arranjos possiveis e sempre atuais. Dessa forma, é importante considerar a realidade como fator desencadeante e desafiador do processo ensino-aprendizagem (fator de exposição).

Busca-se que a prática pedagógica evidencie a ação do discente como transformador de suas relações com os fatores de exposição ao conhecimento e sua prática de trabalho/formação em interação com as diferentes realidades em que pode atuar profissionalmente. Esta perspectiva pedagógica é a de uma aprendizagem ativa, conceitualmente uma perspectiva plural com as características do sócio-interacionismo simbólico, das redes de conversação e da cognição inventiva, explicando o conhecimento como construído, atividade de si e de mundo, atuação dos saberes e transformação singular dos sentidos do fazer. É a ação interrogadora que traz capacidade didática para as atividades de ensino teóricas, teórico-práticas ou prático-aplicativas, remetendo, sempre, o conhecimento para o aprendizado experimentado em ato.

A multiprofissionalidade é componente estratégico na formulação pedagógica das UPPS do Curso de Graduação em Análise de Políticas e Sistemas de Saúde - Bacharelado em Saúde Coletiva, pois o próprio campo de conhecimentos agrega diversidades de saberes, práticas e habilidades profissionais e pressupõe atuação em rede e em equipe, por isso, a organização curricular também deverá considerar a articulação dessa graduação com outras que se configuram como essenciais à produção de conhecimento em Saúde Coletiva, como o grupo de cursos da área da saúde, as ciências sociais, as ciências sociais aplicadas, a engenharia de produção, a educação e as humanidades.

A interdisciplinaridade também é componente pedagógico estratégico para a organização das UPPs, articulando diferentes disciplinas, unidades e núcleos de saberes para uma produção conjunta, coletiva e comum sobre um determinado tema. Estrutura-se como imposição à articulação conhecimentos e práticas na construção de conhecimento e desenvolvimento científico-tecnológico. A interdisciplinaridade se materializa inicialmente pela oferta de Unidades de Produção Pedagógica ao invés da tradicional divisão do conhecimento em fragmentos disciplinares.

Pretende-se a integração de conhecimentos e práticas para a produção de saberes, seja na pesquisa, no ensino e na extensão. Como fator de organização curricular, a articulação de Unidades de Produção Pedagógica em núcleos de conhecimentos e práticas, fortalece a possibilidade de integração dentro da instituição, com áreas, cursos, núcleos e linhas de pesquisa e extensão.

Também como arranjo para uma nova estruturação da construção do conhecimento, é necessária a articulação entre os núcleos de conhecimentos e práticas da área da saúde com as ciências sociais, das ciências sociais aplicadas, da engenharia de produção, da educação 
e das humanidades, potencializando o ensino, a pesquisa, a extensão e a inovação tecnológica na área da Saúde Coletiva, compreendendo que o objeto da área da saúde se dá de forma transversal e pressupõe a integração de diferentes atores, áreas, núcleos e linhas.

Entre outras questões, a criação dessa modalidade de atividade de ensino denominada de "Unidade de Produção Pedagógica" pretende:

- Destacar a combinação de atividades de natureza singular que estão sendo propostas com o modo particular de gerir cada agregado de conhecimentos e práticas que compõem as UPPs;

- Permitir viabilidade institucional para a implementação do projeto político-pedagógico aprovado para o curso, considerando as diferentes atividades de ensino, os registros acadêmicos pertinentes e a atribuição de carga horária docente.

- Associar à experimentação da nova modalidade de atividades o necessário acompanhamento e a avaliação, de forma longitudinal e transversal, para permitir um saldo institucional de conhecimentos sobre essa inovação;

- Viabilizar, sobretudo, modos de interfaciar as UPPs entre si com outras atividades de ensino ofertadas em outros cursos (disciplinas) ou permitir a oferta de módulos temáticos específicos de UPPs a outros cursos, fortalecendo a proposta de desenvolver capacidades multiprofissionais e de conhecimentos interdisciplinares pelo exercício prático nas atividades de ensino.

- Facilitar a transposição curricular e a mobilidade acadêmica, na medida em que essas ações poderão ser embasadas nos planos semestrais, conforme normativas já existentes, e, portanto, tomar as atividades efetivamente desenvolvidas como base para a decisão e não o suposto formal de equivalência de créditos e do campo disciplinar.

\section{REFERÊNCIAS}

i CECCIM, R.B.; FEUERWERKER, L.C.M. Mudança na graduação das profissões sob o eixo da integralidade. Cad. Saúde Pública, Rio de Janeiro, 20(5): 1400-1410, set-out, 2004.

ii LEMOS, C.L.S.; FONSECA, S.G.. Saberes e práticas curriculares: um estudo de um curso superior na área da saúde. Interface - Comunic., Saúde, Educ., 13(28): 57-69, jan./mar. 2009.

iii ABDALlA, I.G.; STELlA, R.C.R.; PERIM, G.L.; AGUILAR-DA-SILVA, R.H; LAMPERT, J.B.; COSTA, N.M.. Projeto pedagógico e as mudanças na educação médica. Revista Brasileira de Educação Médica, 33(1 sup. 1): 44-52, 2009.

iv CECCIM \& FEUERWERKER, 2004. Cit.

v FERLA, A.A.; BATISTA, M.V.; NEUMANN, E.M.; BERTOTTO, M.S.; COLOGNESE, E.T.S.; BERTELE, E.; PANOZZO, N.. Refletindo sobre a formação em enfermagem na Universidade de Caxias do Sul: desafios para o fazer institucional frente às disposições da legislação federal e aos compromissos éticos e políticos de uma instituição comunitária de ensino. 2008. 39 p. Mimeo.

vi CARVALHO, Y.M.; CECCIM, R.B.. Formação e educação em saúde: aprendizados com a Saúde Coletiva. Em: CAMPOS, G.W.S.; MINAYO, M.C.S.; AKERMAN, M.; DRUMOND JR., M.; CARVALHO, Y.M. (Orgs.). Tratado de Saúde Coletiva. São Paulo: Hucitec; Rio de Janeiro: Ed. Fiocruz, 2006. Pág. 149-82. 


\section{Cadernos da}

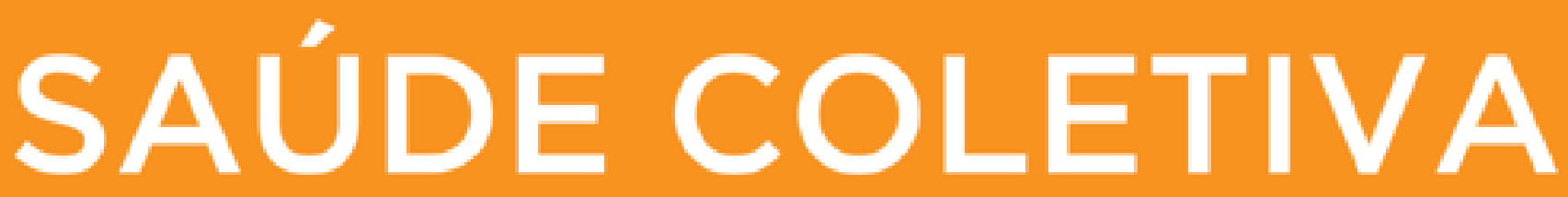

\section{Inovações na formação de sanitaristas}
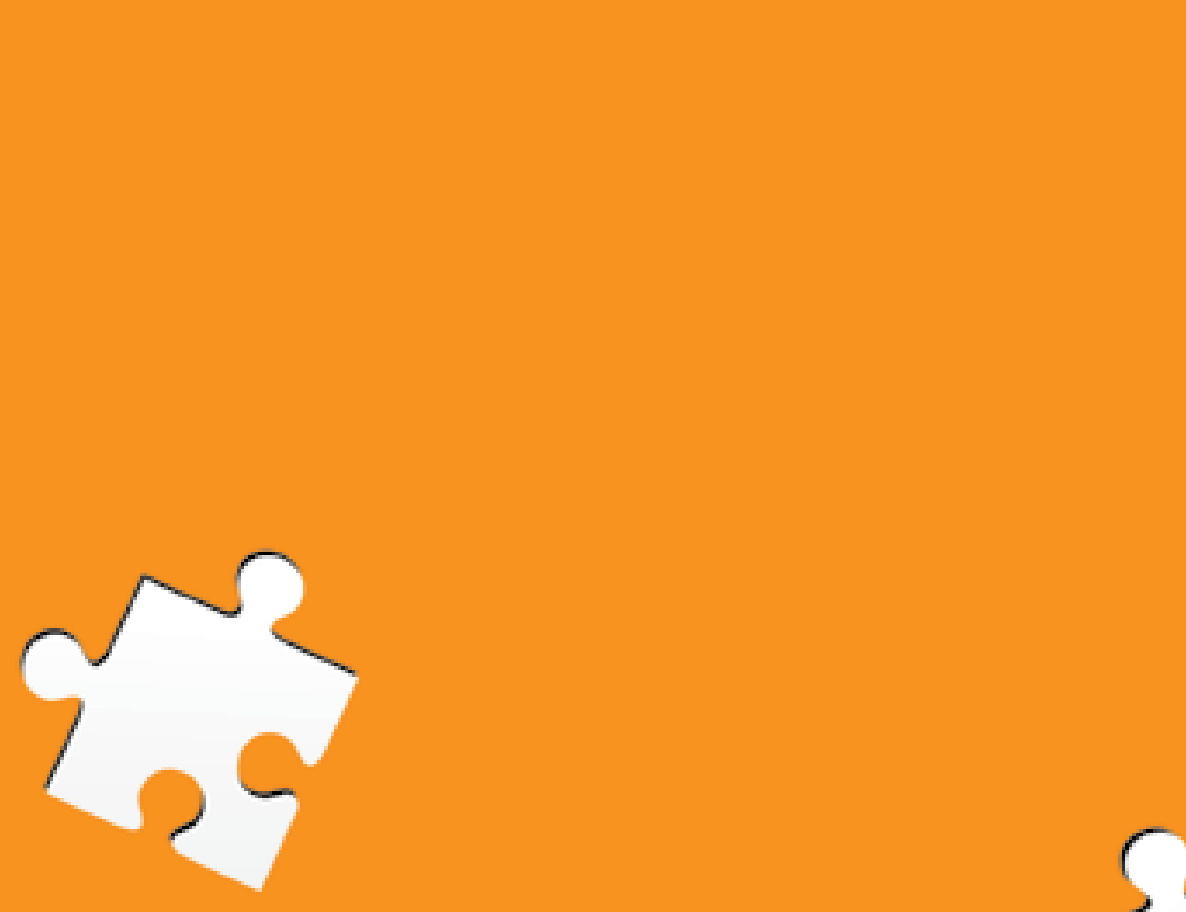